UNIVERSIDADE DE TAUBATÉ

Daniel de Carvalho Costa

\title{
A ATITUDE INTERDISCIPLINAR DOCENTE E O DESENVOLVIMENTO HUMANO: FOCO NO ENSINO MÉDIO DE UMA ESCOLA PÚBLICA
}

Taubaté - SP 
Daniel de Carvalho Costa

\section{A ATITUDE INTERDISCIPLINAR DOCENTE E O DESENVOLVIMENTO HUMANO: FOCO NO ENSINO MÉDIO DE UMA ESCOLA PÚBLICA}

Dissertação apresentada para obtenção do Título de Mestre em Desenvolvimento Humano: Formação Políticas e Práticas Sociais na Universidade de Taubaté.

Área de concentração: Contextos, Processos e Práticas Formativas.

Orientadora: Dra. Ana Maria dos Reis Taino Co-orientadora: Dra. Maria Aparecida Campos Diniz de Castro 
DANIEL DE CARVALHO COSTA

\section{A ATITUDE INTERDISCIPLINAR DOCENTE E O DESENVOLVIMENTO HUMANO: FOCO NO ENSINO MÉDIO DE UMA ESCOLA PÚBLICA}

Dissertação apresentada para obtenção do Título de Mestre em Desenvolvimento Humano: Formação, Políticas e Práticas Sociais na Universidade de Taubaté.

Área de Concentração: Contextos, Processos e Práticas Formativas.

Data:

Resultado:

BANCA EXAMINADORA

Dra Mariana Aranha Moreira José

PUC / SP

Assinatura

Profa. Dra. Marluce Auxiliadora Borges Glaus Leão

UNITAU

Assinatura

Profa. Dra. Ana Maria dos Reis Taino

UNITAU

Assinatura 


\section{Agradecimentos}

Tenho a impressão de que em uma pesquisa sobre o Desenvolvimento Humano os agradecimentos deveriam ser destinados a todos que direta ou indiretamente participaram de minha história e movimentaram meu processo de transformação positiva. Após relembrar a todos, creio ser justo quando então exalto alguns que, com sua participação relevante, profunda e marcante, auxiliaram a construir esse trabalho. Junto deles se apresentou, na vivência cotidiana, tudo aquilo que viria a estudar conceitualmente dentro desse curso de mestrado e é a eles que dedico essas linhas:

Aos meus pais, Adair e Irene, por me apresentarem na prática os valores e os princípios descritos nesse trabalho. Foram e sempre serão meus maiores professores. Com vocês não apenas aprendi sobre desenvolvimento, mas também encontrei os fatores para tanto. Obrigado pela paciência, sobretudo quando os afazeres me encarceravam em meus aposentos.

À professora Ana Reis, minha orientadora, pelo diálogo aberto, franco e, por vezes, conflituoso; pela atuação firme e esclarecedora, capaz de colocar as ideias nascentes na direção da interdisciplinaridade e do desenvolvimento humano.

À professora Nena, co-orientadora do trabalho, pela crença, pelas conversas, pelas aulas. Dialogar convosco me fazia creditar na atitude interdisciplinar docente.

A todos os professores do mestrado, representados pela professora Edna Chamom. Cada perspectiva oferecida por vocês formou a verdade que hoje carrego comigo.

À Thelma, companheira e incentivadora, obrigado pela correção ortográfica, pelo arranjo nas vírgulas e nas concordâncias. Obrigado, sobretudo, por me mostrar que minha história poderia ser contada com novos pronomes e em outra pessoa. Contigo deixo o "eu" para usar o "nós".

Ao meu irmão Renato e a sua esposa Cristina, pelo apoio irrestrito. Aos meus sobrinhos, Vinícius e Lucas; a paixão por vocês me faz querer ser um exemplo constante e melhor.

Aos amigos do mestrado, Alessandro, Arnaldo, Roze, Lucimeire, Fernanda, Chico, Ana Maria, Elaine, Juliana, Malco, Nara, Zilda, Valéria, Karla, Carla, Luigi, Ana Claudia; vocês eram para mim simples desconhecidos, hoje são minha maior aquisição nesse mestrado.

A todos os meus parentes e amigos que acreditaram que o sonho do mestrado fosse possível. 
Antes de filosofar sobre um objeto, é necessário examiná-lo com exatidão. Qualquer explicação ou interpretação deve ser precedida de uma observação e de uma descrição exatas do objeto. [...] Devemos, pois, aprender com um olhar penetrante e descrever com exatidão esse fenômeno peculiar de consciência que chamamos de conhecimento (HESSEN, 2000, p.19). 


\section{RESUMO}

Este estudo pretendeu investigar a existência das manifestações da atitude interdisciplinar entre os docentes e suas relações com o desenvolvimento humano no espaço escolar do Ensino Médio. Ele se justificou ao clarificar os conceitos básicos que sustentavam a pesquisa e que se apresentavam como precípuos em nossos dias - interdisciplinaridade e desenvolvimento humano -, articulando-os de modo a mostrar que a atitude interdisciplinar, quando vivida pelo docente, proporciona transformações positivas para o próprio professor e para os que o cercam. Fundamentaram essa investigação a teoria bioecológica do desenvolvimento humano, idealizada por Urie Bronfenbrenner, e a interdisciplinaridade fenomenológica, cuja representante maior é Ivani Fazenda. A partir da perspectiva de ambos, iniciou-se o diálogo com outros autores na construção da base teórica. Para oferecer concretude a esses pensamentos, utilizou-se a pesquisa qualitativa e como instrumento metodológico a Inserção Ecológica. Sua ligação com os ideais teóricos a colocou como escolha clara, visto que vislumbra os ambientes que influem na pessoa tal como solicita a teoria bioecológica, além de valorizar a subjetividade dos participantes e do pesquisador como quer a interdisciplinaridade. Os resultados obtidos mostraram que os professores que responderam à pesquisa apresentaram uma ideia parcial sobre a interdisciplinaridade, sem apresentar qualquer referência às suas diferentes perspectivas e princípios e sem qualquer efetivação prática. Contudo, algumas atitudes pautadas no dialogo, no respeito, na alteridade, superaram essa defasagem teórica, manifestando-se como interdisciplinares e tais atitudes, a partir do momento em que resgatam, atualizam e potencializam a identidade e os valores da pessoa e os coloca como elemento precípuo da relação recíproca com os outros e com o ambiente, apresentam-se como propulsoras do desenvolvimento humano.

Palavras-chave: Desenvolvimento humano. Interdisciplinaridade. Atitude interdisciplinar. 


\begin{abstract}
This study aimed at researching the existence of the interdisciplinary attitude manifestations between the teachers and their relations with human development in high school environment. It was justified by the basic concepts clarification that supported the research and that were presented as fundamental nowadays interdisciplinarity and human development -, connecting them to show that if the teacher lives the interdisciplinary attitude, this generates positive transformations for himself/herself and for those who are surrounded him/ her. This investigation was based on bioecological theory of human development, thought by Urie Bronfenbrenner, and the phenomenological interdisciplinary, whose the main representative is Ivani Fazenda. From their perspective, the dialogue with other authors begins in the theoretical bases construction. Turning these concrete thoughts, it was used the qualitative research with Ecological Engagement as methodological instrument. Its link to the theoretical ideals places it as a clear choice, because it sees the environment which influences in the person as the bioecological theory asks, besides of value the participating and the researcher subjectivity as the interdisciplinarity wants. The results showed that the teachers who answered the research had a partial idea about interdisciplinarity, without presenting some reference of its different perspectives and principles and without some practice realization. Nevertheless, some attitudes guided by dialogue, respect and othernesse overcame these theoretical differences, appearing as interdisciplinaries. These attitudes, from the moment that they recover, update and potentiate person's identity and values and put them as preciput element of the mutual relation with the others and with the environment, show as generated of human development.
\end{abstract}

Key-words: Human development. Interdisciplinarity. Interdisciplinary attitude. 


\section{SUMÁRIO}

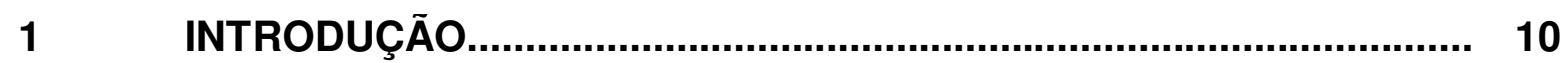

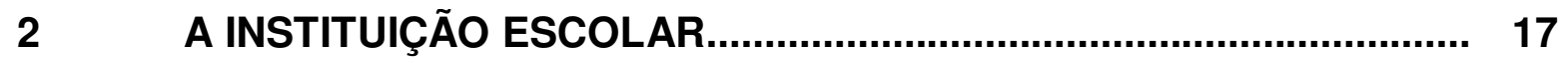

2.1 A BUROCRATIZAÇÃO DA ESCOLA ............................................ 21

2.2 A ESCOLA COMO UMA ORGANIZAÇÃO MECANICISTA.................. 25

2.3 NOVOS RUMOS ORGANIZACIONAIS - A INTERDISCIPLINARIDADE... 29

2.4 ENSINO MÉDIO E INTERDISCIPLINARIDADE............................... 34

$3 \quad$ A INTERDISCIPLINARIDADE................................................... 39

3.1 MULTI, PLURI, INTER E TRANSDISCIPLINARIDADE....................... 43

3.2 AS VISÕES SOBRE INTERDISCIPLINARIDADE.............................. 48

3.3 A INTERDISCIPLINARIDADE NA ESCOLA .................................... 53

$4 \quad$ DESENVOLVIMENTO HUMANO ................................................... 61

4.1 DESENVOLVIMENTO HUMANO E INTERDISCIPLINARIDADE........ 66

4.2 HUMILDADE E DIÁLOGO............................................................. 71

4.3 RESPEITO E ALTERIDADE........................................................ 75

4.4 DESAPEGO E RECIPROCIDADE................................................. 79

4.5 ESPERA E RECONHECIMENTO.............................................. 83

4.6 A ATITUDE INTERDISCIPLINAR COMO PROPULSORA DO DESENVOLVIMENTO HUMANO................................................... 87

$5 \quad$ CAMINHOS PARA A PESQUISA

5.1 PROBLEMA

5.2 OBJETIVOS ........................................................................ 95

5.2.1 Objetivo Geral............................................................................. 95

5.2.2 Objetivos Específicos................................................................. 95

5.3 RELEVÂNCIA DO ESTUDO........................................................... 95 
$6 \quad$ MÉTODO

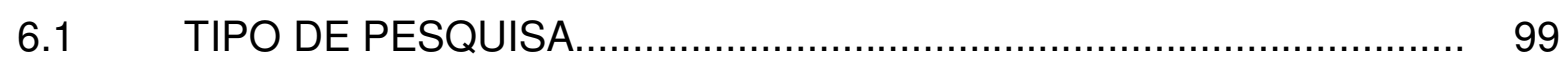

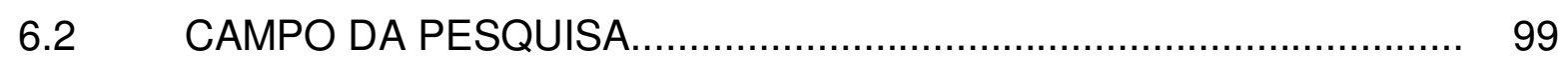

6.3 PARTICIPANTES................................................................. 100

6.4 INSTRUMENTOS E PROCEDIMENTOS DE COLETA DE DADOS.... 100

6.5 PROCEDIMENTOS DE ANÁLISE DOS DADOS............................... 104

7 RESULTADOS E DISCUSSÃO.................................................... 107

7.1 OBSERVAÇÃO................................................................... 119

7.1.1 Macrossistema................................................................... 120

7.1.2 Exossistema............................................................................. 123

7.1.3 Mesossistema.......................................................................... 125

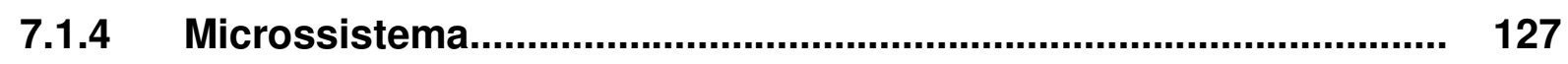

7.1.4.1 Relação entre professores (professor-professor e professor-direção-

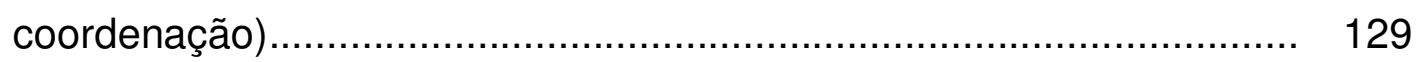

7.1.4.2 Relação entre professores e funcionários......................................... 133

7.1.4.3 Relação entre corpo docente e alunos.............................................. 135

$8 \quad$ CONSIDERAÇÕES FINAIS....................................................... 141

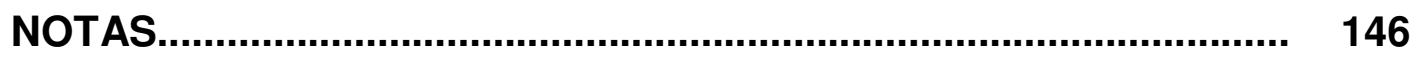

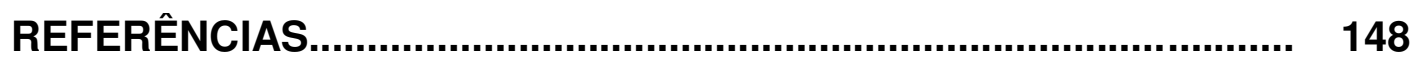

APÉNDICE B - TERMO DE CONSENTIMENTO LIVRE E

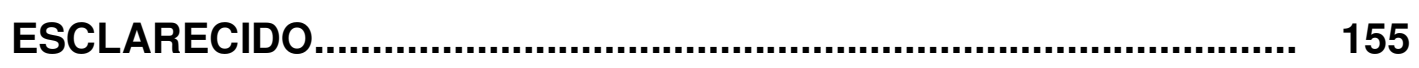

APÊNDICE C - MEMORIAL.................................................... 157

ANEXO A - APROVAÇÃO NO CONSELHO DE ÉTICA.................... 165 


\section{INTRODUÇÃO}

Esta pesquisa representa a procura por um amadurecimento intelectual capaz de questionar e de ampliar os conceitos até então cristalizados pelos anos de estudo em Filosofia e tende a nortear não somente as ideias vindouras deste pesquisador, como também renovar suas atitudes frente ao novo desafio de constantemente aprender.

O propósito almejado encontrou concretude dentro deste trabalho cujo objetivo está em investigar as manifestações da atitude interdisciplinar na prática docente e suas relações com o desenvolvimento humano. $O$ ambiente escolhido para tal evento é a própria escola em que o pesquisador atua, e outra delimitação encontra-se na etapa escolar em que trabalha: o Ensino Médio.

A atuação constante nesse local e com essas pessoas tornou falha a compreensão do professor-pesquisador ao igualar as atitudes realizadas (positivas ou negativas) como normais. Os olhos que sempre contemplaram, não enxergavam nada, reforçando a ideia de que: "O que é mais difícil de tudo? Aquilo que the parece o mais fácil, ver com seus olhos o que está diante deles" (BRONFENBRENNER, 1996, p.29).

A pesquisa possibilita recuperar o olhar crítico, devolvendo ao ambiente sua originalidade; consequentemente, pode-se refazer o que se mostra depreciativo e, por outro lado, ela proporciona reforçar e ampliar o que se apresenta como benéfico.

O construir desse objetivo e os passos definidores deste projeto incitaram, desde o início, inúmeras divergências e conflitos entre aquilo que foi apresentado como proposta no momento do ingresso deste curso de mestrado e os novos modelos conceituais ofertados pelas leituras indicadas.

É em meio a esse debate ideológico que o projeto renasce, carregando o resultado de ser uma radical troca de perspectiva. Assim, um propedêutico trabalho vislumbrando a condição humana, tendo como base as ideias da pensadora alemã Hannah Arendt, ficou esquecido em algum momento deste passado próximo, perdido entre os corredores do prédio de pós-graduação.

Essa troca de viés não aconteceu facilmente. $O$ apego ao tema inicialmente decidido mostrou-se maior que o esperado, motivado que estava pela disciplina de origem. Foi preciso paciência para entender que o projeto primeiro tinha inúmeras 
qualidades, que poderia conduzir ao amadurecimento intelectual tão almejado em um mestrado, mas que, porém, limitava-se a si mesmo, mantinha-se preso dentro das fronteiras de uma disciplina única e distante dos debates apresentados neste curso. Foi necessário despertar toda humildade adormecida para compreender os benefícios de uma nova proposta.

Após um momento de espera, preenchida com análises e reflexões, tal compreensão chegou, sinal de uma consciente e árdua reavaliação dos caminhos anteriormente traçados, de um sereno entendimento do quão longe poderia enxergar e da corajosa aceitação dos desafios que um mestrado em Desenvolvimento Humano impôs e impõe a seus pesquisadores.

Somente após o itinerário descrito é que se lapida o título em questão: "A Atitude Interdisciplinar Docente e o Desenvolvimento Humano: Foco no Ensino Médio de Uma Escola Pública". O referente título traz consigo a pretensão e a ousadia de buscar compilar todos os elementos constituintes deste mestrado. De forma implícita ou explícita, quer-se adotar cada característica identitária e definidora do curso, a saber, a interdisciplinaridade e o desenvolvimento humano.

Sobretudo, quer-se comprovar uma crença, advinda de cada leitura, manifesta em cada reflexão e fortalecida a cada debate, de que a interdisciplinaridade tem com o desenvolvimento humano uma relação recíproca, quase como uma cumplicidade, de modo que a primeira, se transformada em atitude cotidiana, pode auxiliar e favorecer o segundo.

Há algo de evidente nessa relação, e a evidencia é, segundo Descartes (1987), um dos critérios da verdade. Para demonstrá-la, entra em cena a figura do professor, personagem principal da pesquisa, que, com suas atitudes, pode ser o elo entre a interdisciplinaridade e o desenvolvimento humano.

O docente, ao assumir uma atitude interdisciplinar, desenvolve-se, permitindo que o mesmo se faça aos que com ele atuam. Assim o é na medida em que o desenvolvimento é interpretado como toda transformação positiva pela qual a pessoa passa ao longo de sua vida. Esse processo consiste em colocar-se e adaptar-se a situações cada vez mais complexas. Quando isso acontece, a pessoa percebe-se num patamar diferente, reconhece-se melhor do que fora anteriormente, sabe de seu desenvolvimento.

As mudanças, para serem aceitas realmente como desenvolvimento, precisam repetir-se em momentos distintos da vida da pessoa, superando qualquer 
característica efêmera, e em lugares diferentes, ocorrendo em todos os ambientes frequentados; além de superarem o avanço intelectual, agregando também toda transformação física, biológica e psicológica.

Esses conceitos principais que indicam o desenvolvimento estão imbricados à atitude interdisciplinar. Por exemplo, o docente interdisciplinar se coloca em constante aprendizado, buscando respostas para suas indagações, permitindo tornar-se mais preparado, ou seja, melhor a cada momento. Ao encontrar suas respostas e ao partilhá-las, o professor encontra diante de si visões opostas e descrentes à sua, diante das quais precisa se esforçar para manter sua posição. Ao fazê-lo, é sua identidade que também transparece, indicando um desenvolvimento identitário, que se pode caracterizar tanto como pessoal quanto como social.

A busca por novas respostas obtém maior êxito quando existe a participação alheia. O outro completa o conhecimento obtido, dado que a verdade é maior do que aquilo que os olhos de um único pesquisador podem contemplar. Isso, dentro da escola, significa que o professor encontra em seus pares e nos alunos o parceiro ideal na construção de novos saberes. Assim, o desenvolvimento de um é o desenvolvimento do outro.

É nesse sentido que ambos os conceitos - interdisciplinaridade e desenvolvimento humano - não poderiam atuar isoladamente dentro deste trabalho. Seria contraditório fazer dessas linhas apenas esclarecimentos conceituais, assumindo um caráter puramente enciclopédico-teórico. Mais do que retas paralelas que rumam lado a lado, mas que nunca se encontram, o intuito é demonstrar como esses conceitos se articulam, complementando-se e ampliando-se.

Toda clareza e precisão conceitual que justifique e torne essa crença inicial um conhecimento científico é oferecido nos primeiros capítulos desse trabalho. A própria organização dos capítulos foi construída para facilitar a compreensão da mensagem desejada.

A partir disso, para um trabalho intitulado "A atitude interdisciplinar docente...", o mais comum seria iniciá-lo pela própria compreensão da interdisciplinaridade, contudo, esse lugar introdutório é dado à análise do ambiente no qual a pesquisa está sendo realizada e onde o pesquisador e os participantes-objetos se encontram.

Isso acontece, principalmente, porque esse desenvolvimento que se almeja entender, da maneira mais completa possível, acontece sobre um palco. Esse palco é o mundo. Em Filosofia, há uma expressão que denomina essa presença humana 
chamada "ser-no-mundo" e esta relação vai influir, direcionar, atrapalhar ou auxiliar no desenvolvimento humano. Por isso, a relação entre o homem e o mundo é significativa para nós. A opção por este caminho está de acordo com o alerta que o próprio Bronfenbrenner oferece,

É preciso superar antigos hábitos dentro das pesquisas acadêmicas já que o que se tem visto na prática é uma acentuada assimetria, uma hipertrofia da teoria e pesquisa focando as propriedades da pessoa, e somente a mais rudimentar concepção e caracterização do meio ambiente em que a pessoa é encontrada (BRONFENBRENNER, 1996, p.14).

No segundo capítulo, então, possuindo esta fértil informação, tenta-se não sucumbir ao erro de tantos e segue-se a procurar entender o funcionamento da escola. Tal instituição, como todas as outras, exerce forte coação sobre os que nela se inserem, mas também é diretamente influenciada e alterada pelos que a compõem. Nesse intuito, buscou-se analisar as leis que ordenam a escola, particularmente o ensino médio, e como a interdisciplinaridade é colocada dentro deles. Analisou-se também a forma de organização escolar e o modo como as pessoas que a compõem participam em seu cotidiano.

No terceiro capítulo, faz-se a discussão mais profunda sobre a interdisciplinaridade. Nesse espaço, aceita-se a responsabilidade de apresentar um conceito relativamente novo e ainda em construção e que, por isso, segue carregado de inúmeras e variadas definições. É essa mesma dificuldade que dá sentido a esse capítulo, pois, ao tratar da atitude interdisciplinar, é preciso entender o que ela significa na tentativa de superar o senso comum, tão presente na utilização desenfreada e irrefletida do conceito a ponto de banalizá-lo, mesmo com tão pouco tempo de existência.

Para evitar a hipocrisia de juntar o pesquisador ao número dos que falam sem conhecimento prévio é que esse espaço ao esclarecimento da interdisciplinaridade ganha especial atenção. Há nele a procura pelos fatores que propiciam a emergência desse conceito e sua adoção enquanto atitude, enfatizando os avanços das ciências particulares e apontando sua ineficácia em alcançar novas descobertas, dada seu aprisionamento em si mesmo e, com isso, necessitando de uma postura integradora e acolhedora de novas e complementares visões.

Quando a atitude interdisciplinar parece ter sido apreendida, é possível seguir adiante e relacioná-la diretamente ao desenvolvimento humano. Neste quarto capítulo, foi preciso delimitar a compreensão a respeito do assunto, sendo intento 
deixar transparecer qual a definição adotada pelo curso de mestrado sobre o desenvolvimento humano e a teoria bioecológica que orienta seu estudo. Esclarecido, era hora de assumir o desafio e relacioná-lo à interdisciplinaridade.

A atitude interdisciplinar, defendida por Ivani Fazenda (2002), fundamenta-se em princípios importantes que, se adotados pelo docente, modificariam positivamente sua atitude frente ao saber e ao outro. São eles, a humildade, a coerência, a espera, o respeito e o desapego. Cada um desses princípios carrega em seu interior ações que permitem exaltar valores como o diálogo, o reconhecimento, a reciprocidade e a alteridade. As atitudes, ao refletir a combinação entre os princípios e os valores, elevam aqueles que a praticam, tanto quanto enaltecem todos aqueles que com esse indivíduo se relacionam. O que faria do ambiente um lugar de desenvolvimento.

A essa gama de ideias disponíveis no debate, por mais articuladas que estejam, se oferece o perigo de constituírem-se apenas em teorias. Belas, ilustres e dignas palavras, mas, ainda assim, nada mais do que teoria. Goethe, na obra "Fausto" (2009), criticou os filósofos por criarem fantasmas; nos dias atuais, talvez, sua crítica se dirigisse aos pedagogos e pensadores da educação, por apontar devaneios e irrealidades. Para fugir a tamanho equívoco é que se construiu a segunda etapa do trabalho, a pesquisa de campo, exigência da ciência moderna, que está dividida conforme explicitado: delineamento, tipo de pesquisa, local de realização, participantes, procedimentos de coleta e análise de dados.

O quinto capítulo vai apresentar o problema original da pesquisa e o objetivo geral que norteia o pesquisador, além dos objetivos específicos que necessariamente limitam um trabalho com incontáveis possibilidades. Sem eles, essa pesquisa se perderia frente a tantas direções que o estudo da pessoa permite. Ainda nessa etapa, podem-se encontrar as justificativas que indicam a relevância e a pertinência desse estudo.

O sexto capítulo traz a questão do método. As informações que se pretendia buscar, a procura pelos detalhes que indicariam ou não a manifestação da atitude interdisciplinar e do desenvolvimento humano careciam de um instrumento que fosse condizente com tais conceitos. Assim, cada escolha dentro desse capítulo exigiu extremo cuidado e atenção de modo a servir de acesso ao que se desejava. Nele se esclarecem também todas as características da pesquisa, os participantes e 
o local em que foi realizada. Além de descrever os instrumentos escolhidos para a obtenção dos dados e o modo como analisá-los.

No sétimo capítulo, os dados coletados foram colocados à mostra e analisados. Buscou-se uma organização do material que evidenciasse a participação dos docentes e os dados obtidos pela observação do pesquisador. A construção dessa etapa foi feita buscando um diálogo em que três vozes se colocavam num construtivo debate. O pesquisador colocava-se junto aos teóricos que sustentam a pesquisa e com os docentes participantes, cujo saber e atitude verificariam ou não o objetivo proposto.

Por fim, o oitavo capítulo coloca à disposição as considerações finais. Considerações, pois para um trabalho como esse, de caráter interdisciplinar, focando o desenvolvimento humano, não há possibilidade de conclusão. O fim aqui significa apenas a pausa momentânea na busca constante pelo conhecimento e pela compreensão do outro. Pausa a que todo trabalho acadêmico se condena. Se o fim é apenas momentâneo e consequência da academia, essas considerações finais têm uma função mais nobre: a de confirmar este trabalho como a oportunidade de oferecer concretude a uma verdade descoberta pela intuição. Não uma intuição metafísica, de uma "Utopia" como a de Thomas More, nem de uma visão perfeita das coisas, tal como na "Cidade do sol" de Campanella ${ }^{2}$, mas da crença real de que a atitude interdisciplinar pode favorecer o desenvolvimento.

Nessa pesquisa, o resultado da articulação entre a parte conceitual e a parte prática foi o viés escolhido para apontar a interdisciplinaridade como um instrumento real e válido para o desenvolvimento, permitindo verificar sua manifestação na atitude docente de modo que essa transpusesse os limites da teoria, transformandose em ação.

Aos que decidem pela interdisciplinaridade, não basta fazer dela simples conceito. Eles sempre serão parte indispensável da condição interdisciplinar, já que o aprendizado constante é item fundamental desse conceito, porém, é preciso elevála à condição de atitude para que os frutos justifiquem sua existência. A interdisciplinaridade é muito mais do que pura categoria de conhecimento, ela é também ação (FAZENDA, 2000).

Por isso, podemos entender o que diz José Luiz Furtado acerca do equilíbrio entre teoria e prática. 
É-Ihe interditado refugiar-se no mundo dos "a priori eidéticos", onde ganhando em concisão e certeza, se perderia na abstração e no vazio. Assim como não pode, muito menos, se render às evidências factuais dos "estados de coisas" como fundamento exclusivo da sua reflexão ( $I n$ : BORNHEIM, 2009, p.15).

É na atitude consciente do professor que a interdisciplinaridade se concretiza. Quando ela se manifesta junto a si, acontece o desenvolvimento. Seguindo esse "axioma", quer-se analisar se a interdisciplinaridade, feita atitude pelo docente, pode conduzir também a escola a se tornar um ambiente de transformação positiva, onde as pessoas que ali atuam tenham seu desenvolvimento favorecido, tal como tenho vivido ao longo dos anos e como tenho experimentado neste grupo de mestrado. 


\section{A INSTITUIÇÃO ESCOLAR}

Cada pessoa conta sua história situando-a num palco específico; narra a si mesma a partir de um ambiente limitado com o qual vai trocando forças. Esse ambiente, da mesma forma que altera e influi na construção da identidade individual, é também alterado pelo homem. Quando essa relação recíproca se conduz positivamente, a possibilidade do desenvolvimento humano é sempre maior, já que "o desenvolvimento humano é um produto da interação entre o organismo humano em crescimento e seu meio ambiente" (BRONFENBRENNER, 1996, p.14). Dentre tantas verdades, poucas se encaixam tão bem à escola como essa.

O ambiente escolar divide com a família a responsabilidade maior de oferecer às pessoas condições para conduzir bem seu desenvolvimento. Tão belo e precípuo ofício tornou-se lei, expressa pelo artigo $2^{\circ}$ da Lei de Diretrizes e Bases da Educação Nacional (LDB), Lei 9.394, de 20 de dezembro de 1996, em que estipula que a educação é dever da família e do Estado (representado pela escola) na busca pelo pleno desenvolvimento do educando, objetivando ampliar seu preparo para o exercício da cidadania e sua qualificação para o trabalho.

Esse ser único e insubstituível, enquanto paulatinamente se desenvolve, oferece ao seu entorno elementos de sua identidade. Por isso, tamanha importância a escola carrega que momentos que se passam ali dentro ficam marcados na pessoa, como tão bem aponta Gusdorf:

Cada um de nós reserva imagens inesquecíveis do início da vida escolar e da lenta odisséia pedagógica a que se deve o desenvolvimento do nosso pensamento e, em grande parte, a formação de nossa personalidade. Mesmo que o conteúdo do ensino tenha se perdido, ou seja, que o homem tenha desaprendido o que a criança aprendeu, o clima de sua vida escolar continua presente nele: a aula e o recreio, os exercícios e os jogos, os colegas $(1987$, p.1).

O fator que torna a escola um ambiente necessário para a formação do homem está ligado ao reconhecimento de que nela, além do amadurecimento intelectual, da construção e da captação de conhecimento, a pessoa encontra todos os demais elementos para seu pleno desenvolvimento, definido como:

A concepção desenvolvente da pessoa do meio ambiente ecológico, e sua relação com ele, e também como a crescente capacidade da pessoa de descobrir, sustentar ou alterar suas propriedades (BRONFENBRENNER, 1996, p.9). 
$\mathrm{Na}$ escola, cujo ambiente se constrói a partir das relações existentes em seu interior e está diretamente ligado ao contexto externo - sendo ele as famílias envolvidas no andamento da escola, o bairro em que se encontra e sua situação econômica, a cidade e o estado em que se situa - a pessoa se depara com os afazeres necessários para um aprimoramento intelectual e também encontra situações que Ihe permitem o amadurecimento identitário e social.

A participação da escola na vida da pessoa é tamanha que a torna uma:

Instituição fundamental para o indivíduo e sua constituição, assim como para a evolução da sociedade e da humanidade (Davies \& cols., 1997; Rego, 2003). Como um microssistema da sociedade, ela não apenas reflete as transformações atuais como também tem que lidar com as diferentes demandas do mundo globalizado (DESSEN; POLONIA, 2007, p.25).

Essas demandas impostas pelo mundo atual ocorrem todas simultaneamente. Há uma variedade de fatores e de forças em andamento que influenciam significativamente tanto as pessoas quanto as instituições. O que nos leva a afirmar que o entendimento plausível da pessoa desenvolvente só se aproximará efetivamente da verdade se absorver, em sua conceituação, também as instituições com as quais interage, sem descartar outras importantes e decisivas particularidades, tais como o momento histórico e social a que ambos pertencem.

Necessita-se, nesse caso, vislumbrar a instituição escolar a partir do que ela é e do meio ambiente em que se encontra tanto quanto devemos investigar as pessoas que a constituem. Sendo preciso a atenção em manter determinado equilíbrio na apreensão dos fatores que conduzem ao desenvolvimento, valorizando, dessa forma, equitativamente tanto o indivíduo em sua ação e transformação quanto 0 ambiente que $o$ acolhe e influi nessa metamorfose.

Isso impõe entender a escola em suas mais diversas relações. Ela não é elemento isolado dentro de um espaço; ela se liga, interage e altera o espaço que ocupa. Esse meio ambiente tão relevante para o desenvolvimento não se limita a ser único, imediato, mas inclui as interconexões entre ambientes, assim como as influências externas oriundas dos meios mais amplos (BRONFENBRENNER, 1996).

Ao reconhecer e seguir esse caminho multifacetado, a escola plenifica seu caráter social, oferecendo uma educação que abranja os processos formativos que se desenvolvem na vida familiar, na convivência humana, no trabalho, nas instituições de ensino e pesquisa, nos movimentos sociais e organizações da 
sociedade civil e nas manifestações culturais (LDB - BRASIL, 2006, art.1), possibilitando um desenvolvimento positivo. Com isso, mais do que simplesmente conformar-se em um elemento fragmentado, ela efetiva sua pertença à realidade em que se encontra, porque, se a realidade é complexa, também as instituições o são.

Para que tivéssemos essa compreensão, foi preciso um processo de aprendizado tal como nos explica Wagner III e Hollenbeck:

No passado as organizações eram vistas como um sistema fechado, onde
atuava de maneira independente, não permitindo assim que o ambiente
externo a ela pudesse exercer influência no seu comportamento. A partir da
década de 1950, estas passaram a ser consideradas um sistema aberto -
conjunto de subsistemas inter-relacionados - sujeito a influência do
ambiente circunvizinho e, a partir de então, o ambiente passou a ganhar
destaques nos estudos organizacionais ( $I n$ : BRUNDANI; SASSAKI, 2007,
p.11).

A citada abertura pode ser entendida em diversos níveis de interação, partindo de seu entorno imediato, os microssistemas - reduto das relações diretas, face a face -, alcançando os mais amplos, os macrossistemas - que se referem ao nível da subcultura ou da cultura como um todo, juntamente com qualquer sistema de crença ou ideologia subjacente a essas consistências (BRONFENBRENNER, 1996). A escola só permite sua compreensão plena quando considerados todos esses níveis, pois ela se conforma pela ação interna de seus agentes e, concomitantemente, pelas forças que atuam fora dela.

Esse microssistema tão necessário à formação humana, não se constrói apenas pelo levantar das paredes, nem tão pouco pela acumulação de pessoas exercendo dentro deste espaço inúmeras e distintas funções. A escola, para que assuma e cumpra beneficamente seu papel de formação e desenvolvimento, necessita da ação coerente daqueles que a constituem. Isso faz dela o reflexo daqueles que a compõe, o que justifica a seguinte análise:

O ambiente organizacional é definido por Weick (1976), como um ambiente decretado ou ordenado (enacted environment), algo mais do que simples respostas a forças objetivas e também mais do que apenas a percepção e interpretação subjetivas a padrões objetivos: o ambiente é socialmente construído (BRUNDANI; SASSAKI, 2007, p.2).

A instituição escolar precisa que estes mesmos homens a conduzam para que alcance o fim desejado. São as atitudes e, com elas, os diversos procedimentos que se tomam dentro deste ambiente que possibilitarão a escola ser um ambiente positivo ou negativo para o desenvolvimento humano. 
Tais atitudes não estão abandonadas a total liberdade da pessoa, elas baseiam-se em um conjunto de regras ou princípios que delimitam as funções da escola. Assim o é, por exemplo, no artigo $3^{\circ}$ da LDB, quando institui que:

\begin{abstract}
O ensino será ministrado com base nos seguintes princípios:
I - igualdade de condições para o acesso e permanência na escola; II liberdade de aprender, ensinar, pesquisar e divulgar a cultura, o pensamento, a arte e o saber; III - pluralismo de idéias e de concepções pedagógicas; IV - respeito à liberdade e apreço à tolerância; V coexistência de instituições públicas e privadas de ensino; VI - gratuidade do ensino público em estabelecimentos oficiais; VII - valorização do profissional da educação escolar; VIII - gestão democrática do ensino público, na forma desta Lei e da legislação dos sistemas de ensino; IX garantia de padrão de qualidade; $\mathbf{X}$ - valorização da experiência extraescolar; XI - vinculação entre a educação escolar, o trabalho e as práticas sociais (LDB - BRASIL, 1996).
\end{abstract}

Tudo isso impõe certo modo de ser à instituição e aos que nela estão. Com suas regras e normas, ela força cada um, dentro do seu espaço, a conformar-se de acordo com o papel que ali desempenha. Contudo, por mais forte que seja esse fator condicionante, ele nunca é total, de forma que também a instituição fica suscetível em assumir as características desses indivíduos.

As relações de poder, os conflitos, as divisões internas, a identidade progressista ou tradicionalista, tudo isso se manifesta junto ao modo como os integrantes atuam entre si e o reflexo disso está estampado no perfil da própria instituição escolar. Sendo o ambiente composto pelos mais variados tipos de pessoas, "seria relevante afirmar que cada ator organizacional emprega em suas ações, seu estilo próprio de atuação, tendo como base para tais comportamentos sua percepção (ou visão) de mundo" (BRUNDANI; SASSAKI, 2007, p.7).

Para controlar toda essa singularidade e esse jogo de interesses tão habituais na vida humana, as instituições escolares "viram-se diante da necessidade de planejar suas ações e adotar processos lógicos de tomada de decisão e controle do homem no ambiente de trabalho" (SILVEIRA, 2008, p.1109). Tais ações estariam pré-meditadas, sentenciadas por um conjunto de especificações, regras e normas, as quais a pessoa simplesmente se adequaria. Toda individualidade, qualquer forma de subjetividade por parte do trabalhador haveria de sucumbir diante de uma rigorosa descrição da função a ser cumprida. Seria a troca da liberdade do funcionário pela eficiente funcionalidade da instituição. Abandona-se, então, o que era variável em prol do ordinário, emergindo o que ficou conhecido como burocracia. 


\title{
2.1 A BUROCRATIZAÇÃO DA ESCOLA
}

Uma ação primária básica a ser adotada e desenvolvida pelas instituições, a partir das diferenças daqueles que as compõem, seria regular e modular os aspectos racionais dos indivíduos e da coletividade, a fim de obter-se a eficiência e, em última instância, a ordem e a estabilidade social, ou seja, focar os indivíduos nas atividades que precisam desenvolver, diminuindo, já que é impossível anular, os diversos sentimentos que carregam.

Alguns dos meios encontrados para estruturar as instituições e permitir que elas funcionem com eficiência foram dados por Weber (CHIAVENATO, 2003 JAPÍASSU; MARCONDES, 2006 - MAXIMIANO, 2000). Conforme assinala Morgan, o pensador alemão idealizou uma organização racionalizada, baseada na predeterminação total em todos os níveis ou subdivisões do trabalho. Defendia "uma forma de organização que enfatiza a precisão, a rapidez, a clareza, a regularidade, a confiabilidade e a eficiência, atingidas através da criação de uma divisão de tarefas fixas, supervisão hierárquica, regras detalhadas e regulamentos" (1996, p.26).

Essa estrutura social formal, racionalmente organizada com normas e papéis claramente definidos, é conhecida como burocracia e se explica assim:

\begin{abstract}
O sistema burocrático pressupõe a previsibilidade do comportamento dos funcionários. Dentro do marco teórico racionalista, somente através da previsibilidade da ação humana é que se podem estabelecer metas e planejar a ação organizacional. Nessa concepção, os aspectos subjetivos e afetivos do comportamento humano apresentavam-se como disfuncionais à racionalidade dada a sua imprevisibilidade e irracionalidade (SILVEIRA, 2008, p.1109).
\end{abstract}

Uma vez definidos os objetivos e as atividades da organização é possível formular um sistema de regras e de atribuições e competências a serem desempenhados por todos os membros da organização. O indivíduo tem apenas de seguir comportamentos prefixados, geralmente por escrito. Teoricamente, tudo estaria definido e todas as situações estariam previstas - para todas as perguntas e para as muitas situações haveria uma resposta e um procedimento.

No entanto, para o bem ou para o mal, nem tudo está definido, ou melhor, se tudo realmente assim estivesse, não haveria conflito. Regras e normas de funcionamento e execução de atividades estão realmente instituídas e, na 
burocracia, procura-se que as mesmas ordenem e definam o modus operandi. Contudo, a burocracia e o burocrata defrontam-se inevitavelmente com o novo, e, diante da incerteza, procuram conferir o tratamento definido pelas regras, normas e atribuições tal como as interpretam, e essa é a abertura para as variadas ações.

Nas escolas, essa burocratização se apresenta da seguinte forma:

O sistema burocrático estrutura-se em nível de cargos, que por sua vez articulam-se na forma de "carreira", onde diploma acreditativo, tempo de serviço e conformidade às regras constituem precondições de ascensão. Seu modo de recrutamento e sistema de promoção são definidos por ela como sigilo, como mecanismo de comunicação intraburocrático, diluído nas diversas áreas de competência (TRAGTENBERG, 2004, p.46).

O que se pode distinguir dessa opção burocrática proposta por Weber (CHIAVENATO, 2003 - JAPÍASSU; MARCONDES, 2006 - MAXIMIANO, 2000) é que se compõe de um conjunto de dispositivos que envolvem a definição e o esclarecimento de normas administrativas baseadas em áreas limitadas de atuação, a partir do que resulta a distribuição das atividades organizacionais de forma fixa e quase intransponível.

Tamanha delimitação das funções e da hierarquia distribuidora e mantenedora da autoridade dos funcionários fora criada para oferecer um seguimento dos trabalhos, visando a um alto índice de eficiência e à consequente diminuição dos erros advindos, sobretudo, da subjetividade humana. Assim, quanto mais claros e definidos fossem os métodos e as formas de atuação adotados, quanto mais específicas fossem as normas de execução das atividades exigidas, menor se tornava a dependência da instituição no indivíduo que a compunha.

A hierarquia, as normas, as atividades estão representadas pela alta utilização de documentação escrita, devidamente registrada e arquivada. Aqueles que dão conta dessa documentação são responsáveis apenas pelo seu setor ou pela ocupação distinta do cargo em que ocupa, de modo que é impróprio avançar para o afazer do outro. No âmbito escolar, por exemplo, podemos notar essa divisão a partir de uma burocracia de staff (diretor, professores, secretário) e de linha (serventes, escriturários, bedéis), em que os relacionamentos entre staff e linha variam muito, com uma nova subdivisão baseada agora no grau de escola, se médio ou superior (TRAGTENBERG, 2004). Isso dá ao relacionamento pessoal, existente sempre que há um grupo de pessoas que cotidianamente se encontram, um significativo grau de formalidade e impessoalidade. 
Cada funcionário passa a ser exclusivamente um executor de um trabalho completamente planejado, organizado e compartimentado. Sua participação dentro do projeto maior da instituição é fortemente determinada e a não execução dessa tarefa é vista como imprópria; o oposto, representado pelo desejo de realizar o que cabe ao outro, também o é. A decisão e os níveis de autonomia são estabelecidos em função de regras, normas e cargos, e não em função de interesses pessoais.

Pela burocracia almeja-se,

a eliminação das disfunções produtivas e administrativas da sociedade e suas organizações, por meio do controle do comportamento dos indivíduos, a partir de um arranjo social de funcionamento, independentemente dos interesses e afetos humanos; estes devem ser erradicados, para que o sistema funcione continuamente e sem erros (SILVEIRA, 2008, p.1119).

As demandas exigidas pelas constantes e cada vez mais rápidas transformações de nossa sociedade, tanto da sociedade em geral, quanto das organizações públicas e privadas, conduziram o sistema burocrático a um padrão fundamental e indispensável ao mundo atual. Essa quase unanimidade também tem como motivo os interesses do desenvolvimento industrial que requeriam técnicas para viabilizar e administrar o trabalho coletivo em organizações maiores e mais complexas, submetendo os indivíduos a uma ordem superior que buscava o controle produtivo e a ampliação de lucros.

De certa forma, o ponto que conduziu a burocracia a um patamar imprescindível dentro das instituições, o que inclui o âmbito escolar, é o fato de que este, se conduzido da forma desejada, tende a buscar incessantemente o sucesso representado, em nossos dias, pela relação direta ou indireta do aumento do capital. Isso é possível quando os procedimentos escolhidos adotam, se assim podemos considerar, alguns ensinamentos de Maquiavel (2000). Do pensador italiano, aprende-se a diminuir os efeitos do inesperado, do acaso.

O que se quer dizer é que a padronização racional das ações dos indivíduos dentro das instituições "serve para que o destino não seja o responsável por seu sucesso ou fracasso, posição esta alicerçada no paradigma da existência racionalizada, presente no estágio atual de desenvolvimento humano" (SILVEIRA, 2008, p.1119). Isso significa incorporar, na escola, a força do trabalho em detrimento a qualquer tipo de contingência. A distribuição rígida das tarefas permitiria que qualquer eventualidade causasse consequências mínimas ou, pelo menos, dentro de critérios controlados. Atitude tal que condiz ao ensinamento de Maquiavel: 
Comparo a sorte a um rio impetuoso que, quando enfurecido, inunda a planície, derruba casas e edifícios, remove terra de um lugar para depositála em outro. Todos fogem diante de sua fúria, tudo cede sem que se possa detê-la. Contudo, apesar de ter esta natureza, quando as águas correm quietamente é possível construir defesas contra elas, diques, barragens, de modo que, quando voltem a crescer, sejam desviadas por um canal, para que seu ímpeto seja menos selvagem e devastador (MAQUIAVEL, 2000, p.137).

A burocracia baseia-se, então, em um conjunto de características que são cruciais para a sua sustentabilidade e funcionalidade que ainda hoje estão presentes nas organizações, sendo elas: separação da propriedade do cargo; divisão do trabalho; hierarquia da autoridade, dentre outras. Essas produziram efeitos positivos na conformação e na cristalização das instituições ao longo dos anos.

Porém, uma organização guiada por esses princípios também tende a apresentar problemas, o maior deles está na destruição da consciência da instituição e do papel dela como um todo. A burocracia faz da instituição uma linha de produção em que cada um, eficientemente, ocupa-se de suas atribuições, desconhecendo quase sempre o produto final de suas ações.

Cada indivíduo está ciente de sua única e exclusiva função, de modo que se torna alienado quanto ao restante das operações e das influências do seu trabalho para com os outros e dos outros para com ele, ou, quando deseja realizar mais do que exige sua tarefa, se vê impossibilitado de tal.

Isso porque a burocracia está calcada em um ponto terrível, que é:

A despersonalização de relações entre burocracia e público, funcionários de secretaria escolar e o estudante. Ela desenvolve a tendência do burocrata a concentrar-se nessa norma de impessoalidade e a formar categorias abstratas, criando conflitos nas suas relações com o público, pois os casos peculiares individuais são ignorados, e o interessado, convicto das particularidades de seu problema, opõe-se a um tratamento impessoal e categórico (TRAGTENBERG, 2004, p.51).

Outros problemas podem ser listados como a passagem das regras e dos objetivos da organização por meio de ideologias, de forma que o trabalhador ocupe eficientemente seu cargo sem questionar o porquê e o sentido de suas ações, o excesso de disfunções como o formalismo, a resistência a mudanças, a conformidade com rotinas e procedimentos e a grande dificuldade em lidar com os conflitos internos e externos. Tal procedimento invadiu a escola e sua estrutura se repartiu em áreas de atuação hoje pouco comunicativas, o que, dentro da burocracia, reconhece-se como uma forma de organização mecanicista. 


\subsection{A ESCOLA COMO UMA ORGANIZAÇÃO MECANICISTA}

Ao analisar a escola, é possível reconhecer seus aspectos positivos e negativos, sendo todos verdadeiros e simultâneos. Há, dentro da instituição escolar, inúmeras formas de ação que podem estar articuladas entre si ou não e cuja aproximação pode favorecer ou prejudicar a transformação do local em um ambiente de desenvolvimento humano. Como já foi visto, essa transformação está ligada a fatores internos e externos, que vão desde a forma como que se opera a posição e a relação de cada indivíduo dentro da instituição até as leis e normas governamentais e os desejos do mercado fora dela.

Internamente, o que se tem percebido é a escola assumindo uma postura extremamente burocrática ao ponto de compartimentar as atividades, de modo a diminuir e até mesmo extinguir a comunicação entre os setores. Isolados, cada área tende a movimentar-se de maneira singular, a tomar os rumos que acredita mais eficientes, sem ter a ideia do quanto suas escolhas interferem na atuação alheia.

Assim o é porque as instituições, sobretudo a escola, assumiram um caráter mecanicista em sua conformação. A intenção dessa escolha ocorre quando os administradores e as pessoas que a compõem "tendem a administrá-las e planejálas como máquinas feitas de partes que se interligam, cada uma desempenhando um papel claramente definido no funcionamento do todo" (MORGAN, 1996, p.17).

Dentro dessa postura, cada pessoa "inserida em uma organização burocrática é determinada pela sua ação, a qual, por sua vez, é orientada para a consecução dos objetivos da organização em que trabalha" (SILVEIRA, 2008, p.1119). Essa separação e distinção a partir da função contribuem para o andamento frequente da instituição, pois, com a extensão e padronização de regulamentos, com a especialização crescente de tarefas e o uso de equipamentos padronizados, além de uma linguagem própria dentro desses ambientes, cada indivíduo se torna uma peça substituível dentro da máquina institucional.

Como as tarefas são estritamente limitadas, as pessoas que as executam não são mais imprescindíveis, já que se torna muito simples o ensinamento de outro que almeje a este lugar. Na burocracia, o que importa é a impessoalidade, "onde teoricamente cada um deve conhecer as leis e agir em função das ordens abstratas de uma regulamentação estrita" (JAPIASSU; MARCONDES, 2006, p.36). 
É assim que, na escola, a secretaria age com relação aos outros aspectos da instituição, como a direção, a coordenação e os professores (e mesmo entre os docentes, fechados em suas disciplinas). A secretaria não se sente no direito de opinar sobre o modo como a direção conduz a escola nem, tão pouco, como o professorado atua diante da sala de aula; em compensação, guarda-se no mesmo direito de não ser perturbada por aqueles em seu trabalho.

Nesses "guetos", existem até mesmo regras próprias, como por exemplo:

O pessoal de linha administrativa enfatiza algumas singularidades do comportamento burocrático, especialmente evitar a discussão pública de suas técnicas. Os despachos de "processo" são sonegados ao interessado enquanto não se der o chamado "despacho final" no citado processo (TRAGTENBERG, 2004, p.50).

O modo de organização mecanicista gera certa apropriação do espaço e do afazer que se destina a pessoa, de forma que ela se acomode naquela limitada ação que reproduz cotidianamente. $O$ corpo docente e a direção, por exemplo,

O corpo de professores procura manter sua legítima esfera de autoridade
sem intromissões "estranhas". São unânimes na recusa à interferência dos
pais no seu trabalho, pois isso pode prejudicar sua posição e autoridade e
sujeitá-los a controles por elementos estranhos.
Nas suas relações com o diretor, a expectativa de comportamento dos
professores é que recebam apoio do mesmo, seja em relação a alunos ou
pais de alunos. Funciona o princípio de que nenhum professor deva criticar
o colega ante terceiros, especialmente alunos (TRAGTENBERG, 2004,
p.50).

Isso vai gerar uma enorme dificuldade quando as necessidades diárias se afastarem daquilo que é tido como habitual. As respostas para as tarefas são programadas e se age em conformidade com aquilo que estava anteriormente previsto, mas, quando o momento exige uma postura diferente ou uma decisão nova, aqueles que atuam dessa forma sentem-se incapazes de tal ação.

Também a questão de atualização, da absorção de novos conhecimentos de modo a modificar positivamente 0 ambiente em que se encontra tem, no mecanicismo, um elemento dificultador. Toda nova concepção significa a incerteza e a insegurança de uma atuação dentro do desconhecido. Assim, no imaginário funcional, é preferível manter-se com a maneira habitual, cheia de problemas e de limitações, mas de conhecimento de todos a aventurar-se por alguma ideia nova e sem garantias de sucesso.

As organizações mecanicistas atrofiam-se em dificuldades tais como: 
Se adaptar a situações de mudança porque são planejadas para atingir objetivos predeterminados; não são planejadas para a inovação. Isso não deveria causar surpresa, uma vez que as máquinas têm comumente um propósito único, assim como os mecanismos planejados para transformar insumos específicos em produtos também específicos, só podendo engajarse em atividades diferentes, caso sejam explicitamente modificadas ou replanejadas para tanto (MORGAN, 1996, p.38).

A preocupação em resguardar o espaço e a iniciativa da pessoa, permitindo a ela um espaço de pensamento e ação individual no contexto das organizações, emerge justamente da necessidade de que circunstâncias de mudanças, as quais as organizações modernas se impõem frequentemente, exigem tipos variados e inovadores de ação e de resposta. Por isso, as organizações devem preocupar-se em não somente tornar as pessoas mais cooperadas com a administração (SILVEIRA, 2008), mas também tentar evitar que cheguem a converter-se nos felizes autômatos de um "admirável mundo novo".

Quando a autonomia e a criatividade da pessoa não são valorizadas pela instituição, essa se torna refém de suas próprias escolhas, pois, por mais que as normas explicitem os procedimentos necessários em cada situação, elas são limitadas e incapazes de abarcar todas as peculiaridades cotidianas, elas são impotentes ante os diferentes casos provenientes da vida humana. Além disso, a valorização exclusiva da norma abre espaço para outras dificuldades.

Os entraves encontrados são tratados vagarosamente devido a um imobilismo geral e à falta de cooperação entre os agentes da escola. É nessa hora que o acúmulo de trabalho se torna existente, já que, sem a articulação entre as pessoas e entre os setores, as responsabilidades deixam de ser divididas. Assim, ocorre um descompromisso geral, constantemente avalizado por afirmações como "não é minha responsabilidade preocupar-me com isso" ou "é responsabilidade dele, não minha" ou "estou aqui para fazer aquilo que me dizem para fazer".

A burocracia gera, então, um paradoxo em que:

Definir responsabilidades de trabalho de maneira clara e precisa tem a vantagem de fazer com que cada um saiba aquilo que dele é esperado. Mas isso também o faz conhecer aquilo que não é esperado dele. Descrições de trabalho detalhadas têm um caráter de dois gumes, criando muitos problemas quando a organização enfrenta situações de mudança que pedem como resposta iniciativa e flexibilidade de resposta (MORGAN, 1996, p.39). 
Essa passividade institucionalizada e essa dependência podem até mesmo levar os indivíduos a fazer e a justificar erros deliberados sob a premissa de que estão obedecendo a ordens. Muito dessa apatia e descuido frequentemente encontrados nos ambientes de trabalho modernos não é assim pura coincidência: são cultivados pelo enfoque mecanicista da organização que domina o trabalho.

Essa forma de organização estruturou a maneira de se conduzir a escola, mas privou a mesma de toda e qualquer iniciativa. Seu modo de operar exalta as pessoas que simplesmente obedecem a ordens e se mantém em sua posição em lugar de se interessarem por desafiar e questionar aquilo que estão fazendo. Além disso, criou-se dentro deste ambiente a imagem de que as pessoas que questionam a sabedoria da prática convencional são causadoras de problemas.

Um conjunto final de problemas relaciona-se ao fato de que uma estrutura mecanicista impede qualquer ação que tenha como meta um movimento que

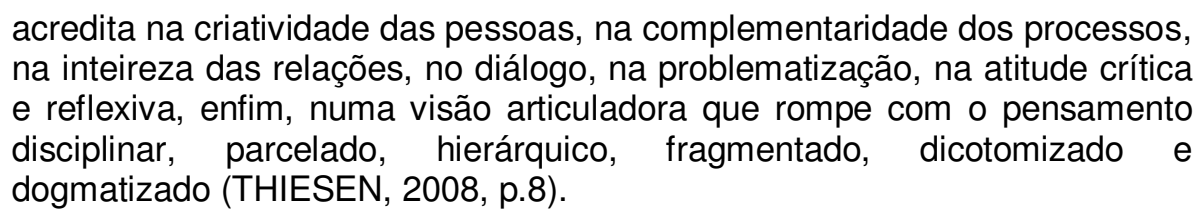

Com isso, o enfoque organizacional tende a limitar as capacidades humanas, evitando o engrandecimento dos que ali convivem, modelando-os para servirem aos requisitos da organização em lugar de construí-la em torno dos seus pontos fortes. Quando os indivíduos tornam-se estagnados, a instituição que os abriga também vê interrompida sua evolução. O desenvolvimento de um está diretamente relacionado ao do outro, "o desenvolvimento humano, individual e coletivo, é a pedra de toque para o desenvolvimento organizacional” (ALARCÃO, 2001, p.47).

O modo de organização mecanicista não é o único existente dentro da escola. Cada área - a secretaria, a diretoria, a sala da coordenação e a dos professores, assim como a sala de aula - pode receber uma postura diferente quanto à sua organização, de acordo com os modos de ação e de relacionamento existentes naquele espaço determinado. São essas atitudes que influenciarão diretamente na transformação da escola em ambiente propício ou não para o desenvolvimento.

Para que a escola torne-se realmente esse ambiente capaz de auxiliar no desenvolvimento, ela precisa organizar-se num espaço que valorize tanto o conhecimento quanto as demais características que envolvem a vida humana, uma possibilidade para atender tamanha intenção pode ser a interdisciplinaridade. 


\subsection{NOVOS RUMOS ORGANIZACIONAIS - A INTERDISCIPLINARIDADE}

Para que a escola encontre novos rumos, é preciso uma nova postura daqueles que a compõem, tanto quanto é preciso uma nova forma de organizar o ambiente em que se encontram. Ela, como lugar legítimo de aprendizagem, produção e reconstrução de conhecimento, do amadurecimento físico e biológico, da construção da identidade, em suma, como local de desenvolvimento humano, cada vez mais precisará acompanhar as transformações da ciência contemporânea - seja na articulação das disciplinas, seja na forma de gerir sua organização -, adotar e, simultaneamente, apoiar as exigências interdisciplinares que hoje participam da construção de novos conhecimentos (THIESEN, 2008).

O mundo do saber, as verdades científicas e o meio organizacional transformam-se em alta velocidade, influenciados pelas mudanças sociais, econômicas, políticas e tecnológicas, precisando adaptar-se para fazer frente a essas mudanças e, assim, optar por fazer-se mantenedora do status quo, a serviço do mercado e das classes dominantes ou tornar-se emancipadora e libertadora, conduzindo e acompanhando a pessoa em seu desenvolvimento.

Essa mudança organizacional é reconhecida por Neiva e Paz como:

Qualquer alteração, planejada ou não, em componentes que caracterizam a
organização como um todo - finalidade básica, pessoas, trabalho, estrutura
formal, cultural, relação da organização com o ambiente -, decorrente de
fatores internos e/ou externos à organização, que traz alguma
conseqüência, positiva ou negativa, para os resultados organizacionais ou
para sua sobrevivência (NEIVA; PAZ, 2007, p.32).

Para que essas mudanças tenham efetivamente novos rumos, uma proposta inovadora se faz necessária. Eis que emerge o chamado à interdisciplinaridade. A atitude interdisciplinar é uma postura adotada por aqueles que atuam dentro da escola - sobretudo pelo docente, foco desta pesquisa - de modo que a articulação entre as diferentes pessoas se reproduza na relação contínua e construtiva entre as disciplinas e entre as repartições pelas quais se divide a escola.

A atitude interdisciplinar passa a substituir os "indivíduos" por parceiros:

Parceiros de quê? Da produção de um conhecimento para uma escola melhor, produtora de homens mais felizes [...] a obrigação é pela alternada satisfação, a arrogância pela humildade, a solidão pela cooperação, a especialização pela generalidade, o grupo homogêneo pelo heterogêneo, a reprodução pelo questionamento (FAZENDA, 1991, p.83). 
Uma mudança na estrutura organizacional que inverta os valores até então corroborados pelo tempo e pela tradição necessita da aceitação de todos. Por isso, é preciso iniciá-la pela transformação da própria atitude daqueles que estão dentro da escola. Atitude pautada em valores como o reconhecimento, a alteridade, a reciprocidade, o diálogo, cuja ação cotidiana permita e potencialize toda transformação positiva que marca a vida da pessoa, tornando-a capaz de construir e ser a si mesma.

A adoção de uma atitude interdisciplinar é um fator de transformação pessoal e não apenas de integração de teorias, conteúdos, métodos ou outros aspectos do conhecimento (FAZENDA, 2002). Ela valoriza as peculiaridades que envolvem a pessoa, sendo, por isso, capaz de propor uma união entre a conscientização das causas da mudança e o interesse que cada um possa ter pela transformação.

Isso por si só é um desafio enorme, pois os valores são mais profundos e duradouros numa organização e alterá-los, por melhor que seja a intenção, é sempre tarefa árdua e lenta; principalmente se comparado aos interesses, que se caracterizam por serem mais voláteis ao longo do tempo, ou seja, "os interesses dos grupos internos à organização mudam de acordo com as circunstâncias, diante de fatos novos internos ou externos e de necessidades emergentes" (BRUNDANI; SASSAKI, 2007, p.8). O que significa que podemos iniciar uma transformação conhecendo os interesses de todos e, a partir deles, negociar politicamente a mudança. Aceitar essa verdade é um fator importante, já que

ao reconhecer que a organização é intrinsecamente política, no sentido de
que devem ser encontradas formas de criar ordem e direção entre as
pessoas com interesses potencialmente diversos e conflitantes, muito pode
ser aprendido sobre os problemas e a legitimidade da administração
(MORGAN, 1996, p.146).

No anseio de encontrar uma solução a essa perspectiva, a interdisciplinaridade atuaria como facilitadora da prática política, uma negociação entre os diferentes pontos de vista para decidir a maneira mais adequada para agir em determinada situação (LENOIR, 2005-2006). O instrumento para isso está em sua característica dialógica. "O diálogo, que parece limitar a verdade ao mecanismo de um debate entre duas inteligências, abre, ao contrário, o campo da verdade graças ao fato de pôr em circulação uma pluralidade de pontos de vista" (GUSDORF, 1987, p.141). 
Essa nova postura que ofereceria novos modos de se organizar o meio ambiente escolar traz suas dificuldades e obstáculos, porém, ela se impõe como necessária, pois, diante dos desafios atuais do mundo moderno, não há mais como lidar com as artimanhas ultrapassadas. Toda conduta burocrática que criou e sustentou uma exagerada dependência dos regulamentos e padrões quantitativos, demasiada impessoalidade nas relações intra e extragrupo, resistências à mudança, configurando os padrões de comportamento na escola encarada como organização complexa, não tem mais espaço (TRAGTENBERG, 2004). Pensar a escola enquanto instituição fechada em si mesma é condená-la ao falecimento, porque

\begin{abstract}
Uma organização não sobreviveria se não mantivesse um relacionamento estreito com o seu ambiente. Ambiente esse que é constituído de diversas forças - por exemplo, normativas, coercitivas, culturais, sociais, entre outras - que farão com que a organização não se permita ao isolamento, mas sim busque, com afinco, uma relativa conformação a essas pressões ambientais, com também legitimidade - reconhecimento de seu valor perante o seu ambiente de atuação (BRUNDANI; SASSAKI, 2007, p.12).
\end{abstract}

Ademais, esse relacionamento com todos os níveis de interação existentes no cotidiano escolar deve privilegiar novos valores. "Se queremos mudar os comportamentos, precisamos mudar os ambientes" (COLE apud BRONFENBRENNER, 1996, p.XIII). Esses podem (e devem) então ser preenchidos por determinados princípios constituintes da interdisciplinaridade, tais como o respeito, a coerência, a humildade, o desapego e a espera vigiada (FAZENDA, 2002); esses princípios abrem-se e ampliam outros valores como o reconhecimento, a alteridade, a reciprocidade e o diálogo, elementos precípuos para o desenvolvimento humano.

$\mathrm{Na}$ assimilação desses princípios, na incorporação cotidiana deles de modo a tornarem-se verdadeiramente atitudes interdisciplinares, o dia a dia se enche de "respeito" ao diferente, que não somente aceita os limites de atuação do outro como também auxilia esse próximo a desenvolver-se, assim como "humildemente" aceita a ajuda alheia. Assume a "coerência" em unir teoria e prática, o "desapego" do antigo frente à necessidade do novo, sem nunca desvalorizar o construído, e a "espera vigiada" ante o momento e o tempo de amadurecimento de cada pessoa que vem a ser diferente para cada um.

Ao romper com a divisão extrema que domina as organizações, a interdisciplinaridade pode conduzir a escola a assumir seu magnífico significado que é ser: 
Um ambiente de vida e, ao mesmo tempo, um instrumento de acesso do sujeito à cidadania, à criatividade e à autonomia. Não possui fim em si mesma. Ela deve constituir-se como processo de vivência, e não de preparação para a vida. Por isso, sua organização curricular, pedagógica e didática deve considerar a pluralidade de vozes, de concepções, de experiências, de ritmos, de culturas, de interesses. A escola deve conter, em si, a expressão da convivialidade humana, considerando toda a sua complexidade. A escola deve ser por sua natureza e função, uma instituição interdisciplinar (THIESEN, 2008, p.8).

Uma ideia inicialmente utópica como esta pode ganhar concretude ao se valer da insatisfação e dos interesses individuais para servir de fator propulsor à mudança. "A pressão para mudança existe na medida em que grupos estão insatisfeitos com o grau em que seus interesses estão sendo realizados nas organizações" (NEIVA; PAZ, 2007, p.33). A partir do momento em que se reconhece o sentimento daqueles que ali estão - o reconhecimento pelo outro, pelo que sente e pelo que pensa também são características interdisciplinares -, pode-se aumentar o grau em que os indivíduos se comprometem com os valores organizacionais propostos, fazendo com que o desejo de mudança e de melhora pessoal que existe neles funcione como precipitador da mudança.

Que não se pense que uma mudança como a desenhada aqui ocorre sem entraves. Como os agentes da mudança são pessoas, essas carregam consigo tanto o desejo coletivo quanto o desejo pessoal; isso significa que um dos elementos existentes nesse processo é o conflito. A citada verdade, conduzida a partir de uma atitude interdisciplinar, indicaria a instauração de um diálogo entre os diferentes interesses, tentando resolver um problema ligado a uma ação ou decisão de modo que todos se sintam valorizados dentro da organização.

O diálogo e a articulação dos variados interesses daqueles que compõem a instituição escolar são muitas vezes decisivos. Sabe-se que "as forças propulsoras existentes no ambiente podem conduzir o resultado da organização em um sentido (satisfatório) ou em outro (insatisfatório) dependendo do posicionamento estratégico adotado" (BRUNDANI; SASSAKI, 2007, p.16). Portanto,

Considerando que a realidade é única, mas que cada um de nós a percebe de forma subjetiva e, portanto, diferente, parece impossível chegar à unidade de pensamento. Em termos práticos, o possível está no diálogo entre as pessoas e na articulação entre disciplinas e modos de organização para resolver problemas imediatos e localizados. Na medida em que as pessoas são bem sucedidas no diálogo interdisciplinar, elas podem se aproximar de um consenso que permita uma ação conjunta, mas dificilmente chegarão a uma unidade que contemple as múltiplas formas de pensar e de agir (HARTMANN, 2007, p.52). 
Se os conflitos forem mal trabalhados, eles tornarão as organizações grandes arenas nas quais coalizões, com diferentes graus de interesses e de envolvimento com os valores preponderantes na organização, tentarão dominar o ambiente. As relações de poder irão sufocar qualquer possibilidade de um trabalho coletivo e de uma busca por um bem satisfatório a todos.

Riscos sempre existem quando se busca alterar um elemento cristalizado. As transformações permitem manifestar uma série de elementos dificultadores da mudança, como vaidades, interesses egoístas, visões individualistas - "muitos programas de mudança nas organizações têm seu fracasso atribuído às resistências dos indivíduos" (NEIVA; PAZ, 2007, p.36). O que significa e justifica a necessidade em adotar uma nova e ousada postura.

É dentro dessa disputa de interesses, sentimentos e razões que a interdisciplinaridade se coloca. Dessa forma, o processo interdisciplinar constitui uma inovação, o que provoca atitudes de medo e de recusa. O que é novo, e não apenas novidade, incomoda, porque questiona o já adquirido, estabelecido e aceito (HARTMANN, 2007). Mas também pode surgir esse conhecimento produzido nas regiões em que as relações se encontram e criam espaços de intersecção, em que o eu e o outro, sem abrir mão de suas características e de sua diversidade, abrem-se disponíveis para a troca e para a transformação (FURLANETTO, 2002).

Para os que possuem uma visão técnica do tema, a interdisciplinaridade é uma ferramenta para superar a fragmentação do ensino e para ousar na forma de organizar uma escola. Ela conduziria a novos conhecimentos e facilitaria à mudança organizacional, alterando a configuração estabelecida para outra mais humana, ativa e participativa. Dessa forma, além de conduzir bem o cotidiano escolar, a atitude interdisciplinar ajudaria a torná-lo um ambiente propício ao desenvolvimento, pois seus princípios e valores interagem com os fatores facilitadores das organizações.

Esses facilitadores são:

Trabalho em grupo, envolvendo unidades e pessoas; (...), direção, flexibilidade e confiança na atuação gerencial; coalizões políticas de apoio à mudança; fluxo de informação abrangente, rápido e preciso; estratégia, refletindo as demandas do ambiente externo; turbulência no ambiente externo; autonomia das unidades e pessoas (NEIVA; PAZ, 2007, p.36).

É justamente uma mudança como essa, capaz de elevar a perspectiva das pessoas que formam a escola, sobretudo dos professores, que se busca dentro dos níveis da formação básica, em especial dentro do Ensino Médio. 


\subsection{ENSINO MÉDIO E INTERDISCIPLINARIDADE}

Como visto, a interdisciplinaridade aponta uma nova forma de fazer ciência e de construir conhecimento. Essa atuação inovadora reconhece o realizado e o constituído pelas mais variadas disciplinas, libertando-as, porém, das fronteiras que atravancavam seu progresso. Ela inspira e propõe uma religação destas áreas, de modo que avancem por respostas mais completas e, assim, mais próximas da realidade complexa que constitui cada pessoa e a sociedade.

Tão importante mudança na elaboração do conhecimento não deixaria ilesos os locais destinados à difusão do saber, aqui aludindo à escola. Nas diferentes etapas que formam, por exemplo, a Educação Básica, composta pela Educação Infantil, Ensino Fundamental e Ensino Médio, exige-se uma atuação diferente, que assuma essa desafiante perspectiva integradora.

Dentre essas etapas, é no Ensino Médio que se verifica grande anseio pela presença da interdisciplinaridade dentro da escola e de uma atitude interdisciplinar por parte dos docentes. Existe a expectativa de que essa nova postura diante do saber auxilie no grande desafio que constitui esse nível de ensino.

Tarefa complicada se levarmos em conta que

o Ensino Médio tem se constituído, ao longo da história da educação
brasileira, como o nível de maior complexidade na estruturação de políticas
de enfrentamento dos desafios estabelecidos pela sociedade moderna, em
decorrência de sua própria natureza enquanto etapa intermediária entre o
Ensino Fundamental e a Educação Superior e a particularidade de atender
a adolescentes, jovens e adultos em suas diferentes expectativas frente à
escolarização (CNE 11, 2009, p.2).

Para tornar essa importante etapa da Educação Básica menos complexa e mais próxima em atender as necessidades da pessoa em desenvolvimento, inúmeras diretrizes foram lançadas pelos órgãos do governo responsáveis pela educação. Todas elas se referem e completam a lei maior da educação nacional que é a LEI no 9.394/96, que estabelece as diretrizes e as bases da educação nacional.

Alguns dos documentos que tratam do Ensino Médio são: a RESOLUÇÃO CEB/CNE no $3 / 98$ que institui as Diretrizes Curriculares Nacionais para o Ensino Médio, fundamentada no PARECER CEB/CNE n 15/98 - que define as diretrizes curriculares nacionais para o Ensino Médio; RESOLUÇÃO CEB/CNE $n^{\circ}$ 4/2010 "Resolução que define Diretrizes Curriculares Nacionais Gerais para o conjunto 
orgânico, sequencial e articulado das etapas e modalidades da Educação Básica, baseando-se no direito de toda pessoa ao seu pleno desenvolvimento" (p.1); essa resolução está baseada no PARECER CEB/CNE № 7/2010, que apresenta as diretrizes curriculares nacionais gerais para a Educação Básica. Todas elas surgem a fim de reestruturar esta importante etapa de aprendizado, oferecendo a ele um objetivo maior, capaz de transpor os limites da simples mecânica de seleção, orientação ou especialização. Seu papel passa, agora, a ser:

De integrar, de criar um sentido em si mesma como lugar de convivência entre gerações e de vivência entre os jovens e, assim, formá-los para viver melhor. Decorre dessa visão a ênfase na construção de uma escola que incorpore a cultura própria da juventude que a compõe. Sugere-se também que a escola média propicie opções para os estudantes, abrindo-se para a diversidade ao mesmo tempo em que se persegue a equidade (ABRAMOVAY; CASTRO, 2003, p. 31).

Completa essa ideia a consciência de que o Ensino Médio é o:

momento de transição e complemento do ensino fundamental e que deve preparar o estudante para o ensino superior, para o mundo do trabalho, para viver em comunidade, para ter um bom senso crítico e para enfrentar os problemas do dia a dia (UNESCO, 2011, p.7).

Ao assumir essa nova identidade, ele "se define na superação do dualismo entre propedêutico e profissionalizante e ganha identidade unitária, ainda que assuma formas diversas e contextualizadas" (CNE 11, 2009, p.2). Esse intento e a obrigatoriedade de novos rumos estão descritos na própria LDB. Mais do que um desejo subjetivo, de pura interpretação individual, o texto da lei oferece claramente os caminhos para tal empreendimento, como pode ser verificado na seguinte citação:

Seção IV - Do Ensino Médio

Art. 35․ O ensino médio, etapa final da educação básica, com duração mínima de três anos, terá como finalidades: I - a consolidação e o aprofundamento dos conhecimentos adquiridos no ensino fundamental, possibilitando o prosseguimento de estudos; II - a preparação básica para o trabalho e a cidadania do educando, para continuar aprendendo, de modo a ser capaz de se adaptar com flexibilidade a novas condições de ocupação ou aperfeiçoamento posteriores; III - o aprimoramento do educando como pessoa humana, incluindo a formação ética e o desenvolvimento da autonomia intelectual e do pensamento crítico; IV - a compreensão dos fundamentos científico-tecnológicos dos processos produtivos, relacionando a teoria com a prática, no ensino de cada disciplina (LDB - BRASIL, 2006).

Essa superação e nova conformação podem ser realizadas pela adoção da interdisciplinaridade. Por ela é possível que a "escola de ensino médio desenvolva um modelo educacional adequado às características e à heterogeneidade dos novos 
grupos e setores sociais que a freqüentam" (UNESCO, 2011, p.5). A presença obrigatória, no Ensino Médio, da interdisciplinaridade acontece por esta apresentar características e caminhos capazes de efetivar os anseios dessa etapa do aprendizado. Quando aprofundamos nosso entendimento em relação ao conceito de interdisciplinaridade, podemos entender os motivos para tanto.

A interdisciplinaridade pode ser entendida a partir de uma tendência epistemológica (LENOIR, 2005-2006 - LENOIR; HASNI, 2004), voltada ao saber, ao conhecimento, à primazia da ideia sobre a ação. Tal perspectiva vem ao encontro da proposta inicial do Ensino Médio cuja identidade atual mantém e reforça a proposta de continuidade do aprendizado. É preciso, nesse estágio escolar, conduzir e acompanhar o aluno em busca de um amadurecimento intelectual.

Esse momento tenciona justificar os conhecimentos adquiridos nas etapas anteriores, corroborá-los e ampliá-los e, principalmente, contextualizá-los. Aproveitando-se da idade do aluno (e do pouco mais de maturidade que esse carrega), a escola pode, com toda qualidade, demonstrar como os saberes ali apreendidos atuam no dia a dia de cada um desses alunos.

A própria contextualização do conhecimento abre uma questão fundamental para o interesse do aluno: "atender a preparação simultânea do jovem para o mundo do trabalho e a prática social” (UNESCO, 2011, p.7). Ainda que o Ensino Médio, em si, não seja responsável por oferecer uma profissão específica ao aluno, esse ensino precisa trazer consigo indiretamente essa característica. Isso se dá quando a formação privilegia a condição de preparar seu alunado para desenvolver qualquer atividade que lhe é proposta. O Ensino Médio conduz o jovem a um desenvolvimento que o faz capaz de apreender, questionar, e criar novos ofícios.

Os desafios diários, a necessidade de ação dentro de um mundo em que a utilidade das coisas ganha destaque, faz com que a escola tenha que se preocupar também com a utilização de seu conteúdo, tem que mostrar a apresentação prática de seu saber. Levando isso em conta é que ela se propõe a oferecer as condições necessárias para a inserção neste conflitante mercado. Para tanto, faz uso de uma visão de interdisciplinaridade mais próxima de uma concepção pragmática americana (LENOIR, 2005-2006 - LENOIR; HASNI, 2004).

Para que ambos os interesses, teóricos e práticos, sejam atingidos, 0 professor tem como parceiro de atividade o próprio aluno. Tanto um quanto o outro colocam à disposição seu conhecimento e, principalmente, suas características, pois 
trazem junto de si suas vivências, suas dúvidas e seus anseios que, quando partilhados, constituem um saber pleno de significado e de veracidade.

Essa valorização do conhecimento cotidiano, muito próximo do bom senso, é efetivamente valorizada pela interdisciplinaridade brasileira, de base fenomenológica (LENOIR, 2005-2006 - LENOIR; HASNI, 2004). Nessa construção de conhecimento, todos são chamados a participar, todos têm igual valor. Essa verdade pode ser vista em vários momentos, porém, na interdisciplinaridade, ela é item obrigatório, já que sozinho o professor é incapaz de atender às necessidades do aluno.

É importante que esta relação complementar entre o intelectual e o profissional dentro do Ensino Médio seja mediada com equidade, e essa característica pode ser encontrada na interdisciplinaridade. Ela permite que o saber tenha parte de sua intenção voltada à prática da atuação profissional, leva a quem dela se apropria a uma condição de seguir pelos caminhos que optar, tornando-se apto a aprender qualquer trabalho.

Ao mesmo tempo, a escola completa essa ação ao valorizar a formação e o desenvolvimento humano. Se as profissões são importantes por nos darem sustento, a formação humana é também essencial pela sua primazia em relação à profissão. Antes de exercer qualquer ofício, o aluno é uma pessoa e, dentro da escola, tem a oportunidade de amadurecer essa condição. A partir do momento em que o humano se exalta, suas relações com os outros e com as instituições também se elevam.

Nesse sentido, a interdisciplinaridade na escola age realmente como um impulso inovador. Oferece uma nova conformação na construção curricular e na relação entre as disciplinas, além de, principalmente, apurar as relações humanas. Pela atitude interdisciplinar, tem-se um testemunho de que tais relações, se bem conduzidas, podem auxiliar no crescimento de todos e na realização de outra característica:

Art. 26. O Ensino Médio, etapa final do processo formativo da Educação Básica, é orientado por princípios e finalidades que preveem (...) 0 desenvolvimento do educando como pessoa humana, incluindo a formação ética e estética, o desenvolvimento da autonomia intelectual e do pensamento crítico (LDB - BRASIL, 2006).

Dito de outra forma, os trabalhos e os esforços individuais conduzem a bons resultados, levam a pessoa a um desenvolvimento pessoal muito grande. Porém, quando esta se abre ao outro, oferecendo e aceitando ajudas, os resultados seguem 
muito além do esperado, pois avançam para além das limitações do indivíduo. O que torna a escola um ambiente libertador diante da imposição individualista do mercado de trabalho. Diante do outro, experimenta-se os desafios das relações humanas, descobre-se a força da dúvida e o peso das decisões. Também se pode reconhecer valores tão importantes para a vida. Assim, vai construindo algo de extremo valor: a identidade, principalmente se focarmos na atuação do professor.

Isso porque a interdisciplinaridade não acontece automaticamente, iniciando com um simples apertar de botões ou por um conjunto de novas diretrizes. Qualquer proposta para a interdisciplinaridade passa pela pessoa do docente, pois não há método programado para sua utilização, nem tão pouco força capaz de coagir para sua aceitação. É a vontade do professor, o desejo dele por algo distinto e melhor transformado em atitude que abre as portas da escola para a interdisciplinaridade.

A escola não será interdisciplinar sem a atitude do professor, mas o docente pode ser interdisciplinar ainda que o contexto escolar não o favoreça. Ele pode apegar-se a essa frutuosa atitude até o ponto de contagiar os que atuam ao seu lado. Dessa forma, ele se mostra, ele oferece o que tem de melhor para o coletivo e, assim, sua identidade se corrobora.

De outros modos, a identidade se manifesta. Por exemplo, na efetivação do currículo escolar: é por força da atitude docente que o currículo ganha características contextualizadas (sem cair em qualquer descaracterização), adequando-as ao ambiente social em que a escola se encontra e ao cotidiano do próprio professor e dos alunos com quem ele atua.

Também quanto à unidade dos saberes, assumindo a ideia de que a "interdisciplinaridade deve ir além da mera justaposição de disciplinas e, ao mesmo tempo, evitar a diluição delas em generalidade" (CNE/CEB 15, 1998, p.38), são os docentes que inicialmente apontam caminhos, criam parcerias para que, aos poucos, os alunos reconheçam com maior naturalidade essa junção, de modo que acompanhem e até ultrapassem o conhecimento de seus professores. Porém, isso só pode acontecer quando há a decisão do professor em apostar nesse caminho.

Encontrar essa atitude que recompõe toda unidade, que dá essa condição de adotar opções tão distintas, é o que faz do Ensino Médio uma etapa precípua e singular dentro do processo de desenvolvimento humano. No entanto, tamanho intento só pode acontecer se a interdisciplinaridade, enquanto instrumento de transformação, for realmente entendida. 


\section{A INTERDISCIPLINARIDADE}

A interdisciplinaridade é o conceito do momento. Com enorme força, tal ideia invade a literatura contemporânea, articulando e sustentando visões e procedimentos das mais variadas áreas. Ao fazermos um recorte donde o privilégio é ofertado aos escritos sobre a escola, nos damos conta de que a proliferação ideológica alcançou índices grandiosos, tornando-se uma peça-chave no modo atual de descrever, avaliar e sugestionar tal instituição.

Essa quase onipresença conceitual explica-se pela condição que a interdisciplinaridade propõe - conduzir a uma superação de um dos mais importantes paradoxos herdado da modernidade: a ciência que no século passado evoluiu em larga escala, que alcançou descobertas fantásticas, transformando radicalmente o modo de viver humano e que foi, aos poucos, se perdendo em incontáveis especializações (POMBO, 1993). Na busca por respostas cada vez mais detalhadas e específicas, a ciência delimitou sua atenção, focou seus esforços em um único objeto e, assim, fragmentou-se tanto a ponto de a comunicação entre os saberes desaparecer.

A ciência que emerge a fim de compreender o mundo se faz cega por seus avanços e descobertas e se esquece de que, neste mundo, as verdades multiplicam-se, sobrepõem-se umas as outras, relacionam-se e oferecem-se todas ao mesmo tempo, num todo multifacetado chamado realidade. Traduzindo, as verdades da Física não acontecem separadas das verdades da História e nenhuma delas isoladas das verdades da Química; ao contrário, ocorrem todas ao mesmo tempo e de forma interligada.

Ter claro os descaminhos da ciência não significa desprezar sua imensa contribuição, "não se pode de forma alguma negar a evolução do conhecimento ignorando sua história" (FAZENDA, 2009a, p.27). A ciência moderna ofereceu um desenvolvimento e uma qualidade de vida nunca antes obtida. As tecnologias, os saberes que hoje desfrutamos são benefícios desse método científico. Contudo, no anseio por responder bem às inúmeras questões oferecidas pelo entorno históricotemporal, a segregação ocorreu e aqueles que se valeram dessa forma foram, aos poucos, incapazes de reagrupá-la num todo mais completo e complexo. 
A maneira de fazer ciência, que tanto ofereceu à humanidade, começou a encontrar problemas em seu desenvolvimento. As fronteiras que estabelecem as disciplinas científicas, o aprisionamento no qual elas se encontram, constituem obstáculos à pesquisa de novos saberes, o que não é compatível com os incessantes processos de inter-relação dinâmica que animavam a constituição do sistema das ciências em seu início (LENOIR, 2005-2006).

Dessa forma, podemos pensar que:

Se, sem especialização, nenhum progresso científico é possível, sem a procura da unidade do conhecimento é a própria ciência que perde o seu mais profundo e verdadeiro sentido, enquanto meio de alargamento da compreensão do mundo e do Homem que o habita (POMBO, 1993, p.175).

Frente a essa necessidade, há o apelo pela interdisciplinaridade, pois

O recurso à interdisciplinaridade se impõem em função da exigência de um outro método de análise do nosso mundo, mas também em função das finalidades sociais, já que as disciplinas sozinhas não poderiam responder adequadamente às problemáticas altamente complexas (FAZENDA, 2009b, p.106).

Essa proposta a que denominamos interdisciplinaridade é capaz de valer-se de todas as idiossincrasias que surgem na busca pelo conhecimento. Ela surge "como um movimento contemporâneo que emerge na perspectiva da dialogicidade e da integração das ciências e do conhecimento, buscando romper com o caráter de hiperespecialização e com a fragmentação dos saberes" (THIESEN, 2008, p.2).

Pela interdisciplinaridade, o que até agora se apresentava como um paradoxo excludente entre a fragmentação do conhecimento e a nova tendência para a unidade do saber passa a ser tratado também como convergente, isto é, enquanto a especialização do saber é responsável pelos avanços científicos e tecnológicos que tão profundamente regularam e determinaram a nossa civilização, a unidade do conhecimento permite-nos uma tentativa de compreensão da condição humana no mundo e de suas necessidades em obter uma transformação positiva de caráter pessoal, social, psicológica, física e biológica, potencializando o desenvolvimento humano. Dessa união de forças entre as ciências, que enfim tende a uma reflexão verossímil a respeito da realidade, podemos inferir que:

Interdisciplinaridade é um método de pesquisa e de ensino suscetível de fazer com que duas ou mais disciplinas interajam entre si, esta interação podendo ir da simples comunicação das idéias até a integração mútua dos conceitos, da epistemologia, da terminologia, da metodologia, dos procedimentos, dos dados e da organização da pesquisa (JAPIASSU; MARCONDES, 2006, p.150, grifo do autor). 
É interessante notar que a proposta até aqui apresentada como um caminho inovador para os problemas epistemológicos atuais é uma espécie de retomada de uma ação já existente e que foi perdida em algum momento da história. O conceito de interdisciplinaridade traz consigo o reconhecimento de que o homem, em sua evolução quanto ao conhecimento e na gênese da ciência, buscava um saber integrado, certo de que a realidade é complexa, exigindo um pensamento abrangente, multidimensional, capaz de compreender a totalidade do real e de construir um saber que leve em consideração essa amplitude (THIESEN, 2008).

Podemos exemplificar essa constatação avaliando que, por exemplo, aquilo que hoje classificamos como um apelo interdisciplinar pode ser interpretado como a manifestação contemporânea do velho ideal de unidade do conhecimento. Essa aspiração constitutiva da própria razão humana teve na Grécia o seu local de origem e, desde então, nunca deixou de se manifestar, dando corpo e alma a alguns dos mais significativos movimentos de ideias da história do pensamento ocidental (POMBO, 1993), como podemos observar em dois pensadores clássicos:

\footnotetext{
Platão e Aristóteles definiram hierarquias entre os saberes, todos eles unificados pela filosofia. Pois, no âmbito do paradigma filosófico, a "filosofia é a ciência dos objetos do ponto de vista da totalidade, enquanto as ciências particulares são os setores parciais do ser, províncias recortadas dentro do continente total do ser" (MORENTE, 1980, p. 31). Para o primeiro, a busca do conhecimento do todo pode ser dividida em Dialética, Física e Ética, que se retroalimentam, e a educação "deve proporcionar ao corpo e à alma toda a perfeição e beleza de que são suscetíveis" (Leis, Livro VI), converter o olhar da alma do mundo sensível para o mundo inteligível e, por fim, levá-lo à contemplação do Bem supremo. Para o segundo, a divisão da ciência em teórica (física, matemática, filosofia), prática (lógica, ética, política) e poética (artes) tem como finalidade o bem moral, a virtude, na qual consiste a felicidade (SOMMERMAN, 2005, p.3).
}

Apesar dessa comparação, a interdisciplinaridade está para além de uma simples reprodução de uma atitude tida em tempos idos, pois é impossível pensar o conhecimento sem a atuação das disciplinas. Assim, esse conceito resgata tal atitude, alarga e amplia seu sentido, adotando, em seu cerne, elementos e valores não salientados em outras épocas. É por conta disso que a interdisciplinaridade, apesar de características comuns, traz também em si uma aura de originalidade.

Dessa maneira, é possível afirmar que a interdisciplinaridade é uma visão nova diante do conhecimento e como tal, como todo conceito em sua gênese, ele está ainda em construção; o que impede qualquer cristalização prematura, qualquer anseio dogmático, já que 
Qualquer demanda por uma definição unívoca e definitiva deve ser a princípio rejeitada, por tratar-se de uma proposta que inevitavelmente está sendo construída a partir das culturas disciplinares existentes e porque encontrar o limite objetivo de sua abrangência conceitual significa concebêla numa ótica também disciplinar (THIESEN, 2008, p.3).

Essa particularidade gera uma série de debates e de indefinições a respeito de sua conceituação, faz da noção de interdisciplinaridade algo polissêmico, abrindo espaço para utilizações equivocadas. Como não há um sentido fechado para ela, "é frequentemente usada como remédio para todos os males e que, de tão usada, pode parecer ser vazia" (POMBO, 1993, p.176). Muitos, sem ao menos tentar entender seu significado e a atitude que a decisão por ela impõe, vão empregando-a no intuito de parecerem atuais, na intenção de que a simples utilização do conceito vai transformar, como em um passe de mágica, o ambiente em que se encontram e a forma como trabalham.

Lenoir (2005-2006), para alertar a respeito desse problema e para conscientizar do risco em perder uma possibilidade de transformação positiva tão importante quanto a interdisciplinaridade, fazendo com que se torne um ideal banal tamanha sua má empregabilidade, vai citar Albert Jacquard ao afirmar que:

Pode-se dizer que é uma palavra semelhante a uma esponja: esta 'absorve pouco a pouco as substâncias que ela encontra, ela (a palavra) se enriquece de todos os sentidos atribuídos por aqueles que a empregam, mas, quando espremida (a esponja), ela se esvazia; repetindo várias vezes, ela (a palavra) corre o risco de não mais ter qualquer significado' (In: LENOIR, 2005-2006).

Essa utilização irrefletida da interdisciplinaridade se vê manifesta numa enorme cacofonia. Tornou-se muito simples utilizá-la, porém, um desafio defini-la. Criou-se uma palavra que todos adoram usar e que poucos conseguem explicar, um conceito sobre o qual não há a menor estabilidade, dado sua recente emergência, mas, mesmo assim, elaboram-se procedimentos e práticas que atravessam vários contextos, que se reproduzem por todo o lado e que teimam em reclamar-se da palavra interdisciplinaridade, dificultando ainda mais sua compreensão.

Potencializa essa dificuldade em definir a interdisciplinaridade a existência de conceitos próximos a esse e que carregam sentidos parecidos. Há pelo menos quatro palavras empregadas na busca por agregar conhecimentos, sendo elas a multidisciplinaridade e a pluridisciplinaridade, a interdisciplinaridade e a transdisciplinaridade, que se diferenciam entre si pelo modo como articulam os diversos conhecimentos. 


\subsection{MULTI, PLURI, INTER E TRANSDISCIPLINARIDADE}

A multidisciplinaridade "diz respeito ao estudo de um objeto de uma única e mesma disciplina efetuada por diversas disciplinas ao mesmo tempo" (NICOLESCU, 1999, p.1). Nessa forma de resposta, não existe nenhuma relação dialética entre os conhecimentos, o que existe é a adoção de um tema comum, sobre os quais representantes de diversas áreas ou disciplinas discorrem, baseados unicamente nos saberes particulares a que defendem.

Não existe a preocupação de formular uma resposta única nem tão pouco há uma linguagem comum, o que se tem é uma variação do mesmo tema, são inúmeras visões para um mesmo assunto, dando a impressão até de que o objeto, ao invés de único, é variado. Baseado nisso, pode-se inferir que:

\footnotetext{
A multidisciplinaridade é a organização de conteúdos mais tradicional. Os conteúdos escolares apresentam-se por matérias independentes umas das outras. As cadeiras ou disciplinas são propostas simultaneamente sem que se manifestem explicitamente as relações que possam existir entre elas. (ZABALA, 2002, p. 33).
}

Ela é constantemente utilizada nas mesas-redondas, nos debates, em que, a partir de um assunto único, representantes apresentam suas convicções. Com esse exemplo deseja-se caracterizar que "O multidisciplinar evoca basicamente um aspecto quantitativo, numérico, sem que haja um nexo necessário entre as abordagens, assim como entre os diferentes profissionais" (COIMBRA, 2000, p. 57).

$\mathrm{Na}$ escola, também é utilizada quando trabalhos são elaborados e a única relação entre as disciplinas e os professores está no tema em comum. Em nenhum momento, o conteúdo alheio questiona e altera a resposta do outro. Cada um assegura-se de seu saber, negando qualquer participação de uma ciência exterior.

A pluridisciplinaridade (que muitos autores tratam como se fosse sinônimo de multidisciplinaridade) apresenta um pequeno avanço em relação à troca de conhecimento entre algumas áreas, normalmente áreas afins. O que se reconhece nessa articulação entre as disciplinas é "algo que é dado na sua forma mínima, naquilo que seria a pluri (ou multi) disciplinaridade, que supõe o pôr em conjunto, o estabelecer algum tipo de coordenação, numa perspectiva de mero paralelismo de pontos de vista" (POMBO, 2008, p.13). Com essa pequena relação 
- objeto sairá enriquecido pelo cruzamento de várias disciplinas. O conhecimento do objeto em sua própria disciplina é aprofundado por uma fecunda contribuição pluridisciplinar. A pesquisa pluridisciplinar traz um algo a mais em questão, porém este "algo a mais" está a serviço apenas desta mesma disciplina. Em outras palavras, a abordagem pluridisciplinar ultrapassa as disciplinas, mas sua finalidade continua inscrita na estrutura da pesquisa disciplinar (NICOLESCU, 1999, p.2).

Para entender melhor, pode-se avaliar a pluridisciplinaridade como a justaposição de disciplinas mais ou menos próximas, dentro de um mesmo setor de conhecimentos. É uma forma singela de cooperação, com pouca qualidade em relação à organização que visa melhorar as relações entre essas disciplinas. Vem a ser uma mera troca de informações, uma simples acumulação de conhecimentos.

Um elemento positivo dessa intercomunicação é que se produz um plano de igual para igual, sem que uma imponha sua visão à outra, baseando-se, por exemplo, em que, em um determinado momento, certa disciplina goza de uma situação privilegiada ou de maior prestígio que a outra. Entretanto, não se contribui para uma profunda modificação da base teórica, problemática e metodológica dessas ciências em sua individualidade. É uma comunicação que não as modifica internamente. Nesse nível, ainda não existe uma profunda interação e coordenação.

"No que diz respeito aos conceitos de multidisciplinaridade e de pluridisciplinaridade, há quase um consenso" (SOMMERMAN, 2005, p.4). As duas outras palavras existentes, interdisciplinaridade e transdisciplinaridade vão oferecer um maior desafio conceitual. Apesar da diferenciação construída para ambas, é ainda muito difícil delimitar onde acaba uma e onde começa outra. Diferentemente da multi e da pluri, tanto a inter quanto a trans carregam aspectos comuns, o que torna decisivo a opção do autor que a emprega.

A interdisciplinaridade, por exemplo, surge quando se consegue ir além do simples paralelismo e "se avança no sentido de uma combinação, de uma convergência, de uma complementaridade" (POMBO, 2008, p.13). É quando as fronteiras disciplinares se abrem a saberes diferentes dos quais estão habituados.

Sua opção supera os limites criados nas opções anteriores, de modo que valoriza a disciplina, não se limitando a ela; coloca as disciplinas lado a lado e as conduz por uma junção de forças. É nesse sentido que se pode afirmar que:

A interdisciplinaridade é a interação de duas ou mais disciplinas. Essas interações podem implicar transferência de leis de uma disciplina a outra, originando, em alguns casos, um novo corpo disciplinar, como, por exemplo, a bioquímica ou a psicolingüística (ZABALA, 2002, p. 33). 
É quando a matemática se vale da literatura, quando a biologia se junta à ética, é quando, independentemente do conhecimento que se defenda, esses se aproximam, se questionam e se completam mutuamente, possibilitando respostas que nenhuma das disciplinas originárias seria capaz de obter isoladamente.

Mais até do que a simples articulação curricular, a importância da interdisciplinaridade está na transformação da própria atitude de quem busca o conhecimento, ofertando ousadia e comprometimento aos seus desbravadores, permitindo que a ligação entre os saberes não se limite à pura junção disciplinar, mas que consiga ligar-se verdadeiramente com o cotidiano e seus desafios, ou seja, a interdisciplinaridade leva os pesquisadores e os docentes a construir conhecimentos conectados com o dia a dia, dotados de plenos significados ao referirem-se objetivamente à vida.

Essa mudança proposta para a escola, essa transformação na atitude do docente exige alguns critérios esclarecido por Georges Gusdorf:

Estudos interdisciplinares autênticos supõem uma pesquisa comum e a
vontade, em cada participante, de escapar ao regime de confinamento que
lhe é imposto pela divisão do trabalho intelectual. Cada especialista não
procuraria somente instruir os outros, mas também receber instrução. Em
vez de uma série de monólogos justapostos, como acontece geralmente,
ter-se-ia um verdadeiro diálogo, um debate por meio do qual, assim se
espera, se consolidaria o sentido da unidade humana. (...) A determinação
de uma língua comum é a condição do surgimento de um saber novo (In:
SOMMERMAN, 2005, p.6).

Um passo adiante na construção de um conhecimento capaz de abarcar as até então conflitantes formas de saber é a transdisciplinaridade. Ela seria como algo "que se aproximasse de um ponto de fusão, de unificação, quando fizesse desaparecer a convergência, nos permitiria passar a uma perspectiva holista" (POMBO, 2008, p.14).

A transdisciplinaridade seria uma única forma de saber abastecida pelas disciplinas, mas diferente delas. Tal como o corpo humano a funcionar a partir do trabalho de seus órgãos e que mesmo assim continua a ser um corpo humano, as disciplinas trabalham em suas perspectivas particulares para colocar seus resultados de volta ao todo, sem nenhuma separação. Por isso ela

envolve aquilo que está ao mesmo tempo entre as disciplinas, através das diferentes disciplinas e além de toda e qualquer disciplina. Sua finalidade é a compreensão do mundo atual, para a qual um dos imperativos é a unidade do conhecimento (NICOLESCU, 1999, p.2). 
Para melhor explicitar o que representa a transdisciplinaridade, é possível escolher alguns artigos, de um documento elaborado pela UNESCO intitulado "Carta da transdisciplinaridade". Nessa carta, - a qual destacamos os artigos 1 e 3 - alguns pontos ficam esclarecidos, tais como:

Artigo 1: Toda e qualquer tentativa de reduzir o ser humano a uma definição e de dissolvê-lo no meio de estruturas formais, sejam quais forem, é incompatível com a visão transdisciplinar.

Artigo 3: A transdisciplinaridade é complementar da abordagem disciplinar; ela faz emergir novos dados da confrontação das disciplinas que as articulam entre elas; oferece-nos uma nova visão da natureza da realidade. A transdisciplinaridade não procura a mestria de várias disciplinas, mas a abertura de todas as disciplinas, ao que as atravessa e as ultrapassa (UNESCO, 1994).

A mesma carta, em seu artigo seis, apresenta uma tentativa de diferenciação entre multidisciplinaridade, interdisciplinaridade e transdisciplinaridade:

Em relação à interdisciplinaridade e à multidisciplinaridade, a transdisciplinaridade é multirreferencial e multidimensional. Ao mesmo tempo em que leva em consideração as concepções do tempo e da história. A transdisciplinaridade não exclui a existência de um horizonte transitório. (UNESCO, 1994).

Corroborar as diferenças entre multi, pluri, inter e transdisciplinaridade ainda é um trabalho a ser concretizado, mas, se pensarmos em tais palavras como um continuum que vai da coordenação à combinação e desta à fusão, se juntarmos a essa continuidade um crescendum de intensidade, teremos qualquer coisa deste gênero: do paralelismo pluridisciplinar ao perspectivismo e à convergência interdisciplinar e desta ao holismo e à unificação transdisciplinar (POMBO, 2008).

Outro autor, Santomé, vai demonstrar a passagem de um nível de tratamento entre as disciplinas de forma hierárquica a partir de uma proposta feita por Piaget:

1. Multidisciplinaridade. O nível inferior de integração. Ocorre quando, para solucionar um problema, busca-se informação e ajuda em várias disciplinas, sem que tal interação contribua para modificá-las ou enriquecê-las. Esta costuma ser a primeira fase da constituição de equipes de trabalho interdisciplinar, porém não implica em que necessariamente seja preciso passar a níveis de maior cooperação.

2. Interdisciplinaridade. Segundo nível de associação entre disciplinas, em que a cooperação entre várias disciplinas provoca intercâmbios reais; isto é, existe verdadeira reciprocidade nos intercâmbios e, conseqüentemente, enriquecimentos mútuos.

3. Transdisciplinaridade. É a etapa superior de integração. Trata-se da construção de um sistema total, sem fronteiras sólidas entre as disciplinas, ou seja, de 'uma teoria geral de sistemas ou de estruturas, que inclua estruturas operacionais, estruturas de regulamentação e sistemas probabilísticos, e que una estas diversas possibilidades por meio de transformações reguladas e definidas (1998, p.70). 
Isso pode estar claro no papel, mas, na prática, as ações se confundem. Tamanha dificuldade se dá ao avaliar que as disciplinas fazem parte do cotidiano das ciências a um longo tempo, período esse que fortaleceu e corroborou sua presença nos ambientes de conhecimento, tais como as escolas e as universidades. Dessa forma, cada professor aprende, desde a graduação, a comportar-se e a pesquisar de forma disciplinar e é justamente essa postura que ele reproduz em seu ofício. Sua única variação se encontra numa postura multidisciplinar em que pode, ao lado de outros, colocar seu conhecimento sem a mínima preocupação com qualquer tipo de relação, sem se importar se tal saber é contraditório ao do colega ou se realmente ambos os conhecimentos condizem com a realidade.

Quanto à interdisciplinaridade e à transdisciplinaridade, ambos os conceitos se misturam. Suas semelhanças dificultam sua conceituação. A impressão que existe sobre tais ideias é o de que, antes mesmo de a interdisciplinaridade ser entendida e vivenciada, outro modo de tratar o conhecimento - a transdisciplinaridade - se fez. Com isso, um conceito ainda em construção entrou numa disputa de identidade, em que se discute o que cabe a um e o que cabe ao outro sem que se saiba realmente o que ambas são. Contudo, as duas apontam o caminho para a obtenção do conhecimento no terceiro milênio e a tentativa de se delimitar e entender uma traz o entendimento e o avanço da outra.

Feita toda distinção possível entre as palavras atualmente utilizadas para demonstrar uma nova postura diante do conhecimento, é possível retomar o foco desta pesquisa: a interdisciplinaridade. $O$ caos aparente, ao invés de generalizar-se em uma deficiência intransponível, foi absorvido pelo próprio conceito, de modo a se tornar elemento essencial para sua compreensão. Cada nova tentativa de formular uma definição e um limite para a interdisciplinaridade contribui para sua elaboração e enriquecimento, mais do que isso, a interdisciplinaridade incentiva essa constante participação, de forma a manter-se sempre atualizada.

Essa aparente instabilidade não pode esconder os progressos no estudo da interdisciplinaridade. "O cuidado primeiro é encontrar o ponto ótimo de equilíbrio no movimento engendrado por essa ambiguidade: da imobilidade ao caos" (FAZENDA, 2002, p.18). O mencionado ponto de equilíbrio está baseado no desenvolvimento de algumas vertentes que podem ser identificadas a partir de seu modo peculiar de integração com o conhecimento, fundamentado em suas culturas e no modo como interpretam e lidam com o mundo. 


\subsection{AS VISÕES SOBRE INTERDISCIPLINARIDADE}

Passado o período de gestação conceitual e alcançando este momento de amadurecimento e corroboração já se destacam, no âmbito da interdisciplinaridade, duas grandes e distintas orientações. As diferentes leituras justificam-se no fato de que "los actores sociales, los investigadores, los formadores universitarios o los docentes están involucrados con culturas que son el origen de estas diferenciaciones conceptuales y de su uso" (LENOIR, HASNI, 2004, p.167).

Por um lado, há uma visão européia, representada pela escola francesa, defensora do ponto de vista epistemológico, da pesquisa como síntese conceitual, quer dizer, a pesquisa tendo como preocupação central a apreensão do sentido, da conceitualização, da compreensão que permite recorrer aos saberes interdisciplinares em prol de uma unificação das ciências e do saber.

Trata-se de extrair com uma preocupação de unificação das ciências, primeiramente, uma estruturação coerente e solidamente articulada hierarquicamente entre as diferentes disciplinas constitutivas da ciência (LENOIR, 2005-2006, p.10).

Esta propicia a condição de auxiliar, por exemplo, no desenvolvimento intelectual, na busca pela apreensão da realidade, na compreensão do contexto a qual se pertence, de modo que a vertente epistemológica se faz presente oferecendo um campo de visão e de análise cada vez mais amplo e complexo, formando, assim, uma espécie de superciência.

Nessa visão, o que vale é a constituição de um quadro conceitual global, ou seja, nesse modo de produzir conhecimento, a característica primordial dá-se pelo saber teórico. Antes de qualquer ação, antes de qualquer decisão, é importante problematizar o saber, questionar-Ihe e desvendar-Ihe o sentido. Em suma,

é preciso enunciar claramente os motivos que tornam necessário sair das rotas acadêmicas já bem balizadas; apontar as necessidades científicas que demandam inovações no domínio da pesquisa e da pedagogia; e os objetivos a serem atingidos no processo de produção do saber (RAYNAUT, 2011, p.71).

Altamente intelectualista, essa vertente apresenta a tentação de desvalorizar a opinião popular. Toda doxa é tida como parte do senso comum e este é compreendido como lugar do erro, como um pensamento superficial e sem reflexão, 
que, ao invés de preencher-se com verdades, ilude-se com ideologias. Assim, o conhecimento popular, adquirido pela experiência dos anos vividos, corre o risco de ser negado e abandonado por não se encaixar em nenhum método científico.

Por outro lado, a vida humana se constitui também por problemas cotidianos que transcendem as fronteiras do simples intelectualismo. Há situações em que a experiência e a vivência oferecem soluções imediatas e melhores para os desafios que se apresentam. Nesse sentido, a interdisciplinaridade contribui para a ampliação desses práticos saberes, ofertando as visões desenvolvidas pela escola americana.

Essa singular visão a respeito da interdisciplinaridade está impregnada de um modus operandi intimamente relacionado a um tipo de visão pragmática e utilitarista. Deriva disso a compreensão de que a pesquisa e os novos conhecimentos rumam para respostas operacionais, para questões sociais ou tecnológicas pelo intermediário de abordagens instrumentais. "Sua preocupação central é o da pesquisa da funcionalidade" (LENOIR, 2005-2006, p.12).

A ideia máxima está em promover a busca por um saber diretamente útil, aplicável no dia a dia e capaz de resolver os problemas que se apresentam de forma rápida, hábil e eficiente. Geralmente, pode-se exemplificar essa corrente a partir do cotidiano das questões sociais contemporâneas e para qual a solução adotada segue o viés de uma prática política, ou seja, uma negociação em que diferentes pontos de vistas são apresentados e avaliados para, enfim, se decidir por uma ou por outra visão considerada, naquele momento, mais apropriada aos fins desejados.

Aqui, a questão da interdisciplinaridade não é antes de tudo teórica, como analisamos na vertente anterior, ela é pragmática e organizacional; por isso, facilmente perceptível nos ambientes de formação profissional, por exemplo. O que torna o homem livre "no está relacionado directamente con los conocimientos, sino con la capacidad de actuar en y sobre el mundo" (LENOIR, HASNI, 2004, p.171).

Esta denominada ordenação social busca ligar o desdobramento dos saberes científicos interdisciplinares às exigências sociais, políticas e econômicas (FAZENDA, 2009b). Isso gera a preocupação em não permitir que as relações de poder interfiram nas decisões, de modo que as escolhas acabem por privilegiar uma determinada classe ou grupo social.

Apesar de distintas, ambas as vertentes rumam para um mesmo objetivo, um saber capaz de apresentar uma resposta cujo alcance atinja o maior grau de complementaridade e, com isso, de verossimilhança, possível. Independente da 
definição que cada autor assuma, a interdisciplinaridade está sempre situada no campo onde se pensa a possibilidade de superar a fragmentação das ciências e dos conhecimentos produzidos por elas e onde simultaneamente se exprime a resistência sobre um saber parcelado (THIESEN, 2008).

A opção por cada uma delas não está nelas mesmas, mas no homem que há de se valer delas, isto é, seja um conhecimento epistemológico, seja um conhecimento prático, ambos só têm sentido se ligados à vida humana. Somente ganham especial lugar em nossas discussões se evidenciam o homem, se entram em acordo com a necessidade, com os questionamentos, com o cotidiano da pessoa, se, enfim, exaltam as pessoas que constroem esse saber.

Por isso, uma nova opção vem conquistando respeito e espaço, apresentando-se como uma terceira via de interpretação. Ela é uma vertente brasileira da interdisciplinaridade a partir do que expõe Fazenda (1991, 2000, 2002, 2003, 2005, 2009a, 2009b) e está centrada na pessoa, na qualidade de ser humano e procede, então, segundo uma abordagem fenomenológica. Também podemos distingui-la das demais ao acompanhar que a lógica francesa é orientada em direção ao saber, a lógica americana sobre o sujeito aprendiz, já a lógica brasileira é dirigida na direção do terceiro elemento constitutivo do sistema pedagógico-didático, o docente em sua pessoa e em seu agir (LENOIR, 2005-2006).

A concepção nacional traz a si o que as visões anteriores têm de melhor e as complementa ao valorizar aquele que a produz a partir sempre de sua singularidade e de sua história de vida. Por isso, é "capaz de perceber o que nenhum outro pode, por isso é capaz de sentir o que nenhum outro sente" (FAZENDA, 2002, p.15) e, quando tais percepções são partilhadas, o amadurecimento é mútuo, elevando tanto a quem o oferece quanto a quem o recebe. Isso de forma perceptível, pois a atitude interdisciplinar se manifesta aos olhos de todos.

\footnotetext{
Entendemos por atitude interdisciplinar, uma atitude diante de alternativas para conhecer mais e melhor; atitude de espera ante os atos consumados, atitude de reciprocidade que impele à troca, que impele ao diálogo - ao diálogo com pares idênticos, com pares anônimos ou consigo mesmo atitude de humildade diante da limitação do próprio saber, atitude de perplexidade ante a possibilidade de desvendar novos saberes, atitude de desafio - desafio perante o novo, desafio em redimensionar o velho atitude de envolvimento e comprometimento com os projetos e com as pessoas nele envolvidas, atitude, pois, de compromisso em construir sempre da melhor forma possível, atitude de responsabilidade, mas, sobretudo, de alegria, de revelação, de encontro, enfim de vida (FAZENDA, 2000, p.82).
} 
A primazia ante qualquer saber está no ser humano. A interdisciplinaridade valoriza toda experiência individual e ainda mantém a interação com o outro sempre ativa; é nessa troca de ideias que a pessoa constrói sentidos que definem sua forma particular de ação nos diversos contextos de desenvolvimento. Isso produz uma nova forma de atitude e, consequentemente, uma nova forma de pensar, elaborando uma equação em que todos os fatores são essenciais (eu + circunstância/contexto), convidando todos à participação. Cada conhecimento, por mais ingênuo que seja, torna-se parte importante na apreensão da realidade.

Nessa vertente, o senso comum, tão criticado em momentos outros da história do conhecimento, recebe seu valor enquanto primeira forma de saber vinda da realidade e baseada na tradição, na experiência e nos grupos sociais a que o indivíduo pertence. "Pelo senso comum fazemos julgamentos, estabelecemos projetos de vida, adquirimos convicções e confiança para agir" (ARANHA, MARTINS, 1998, p.70). É a partir deles que se mobilizam novas atitudes em busca das respostas que possam atender as inquietações do indivíduo.

Mesmo com a explicação anterior, o termo "senso comum" carrega consigo um significado pejorativo, o que nos leva, para melhor se entender sua participação dentro da interdisciplinaridade, a troca-lo por algo mais elaborado tal como o bom senso. Nele ocorre a elaboração refletida e coerente do saber a partir da explicitação das intenções conscientes dos indivíduos livres, que são, portanto, ativos, capazes de críticas e donos de si mesmos. Se o senso comum tende à rigidez, ao dogmatismo e até ao fanatismo, o bom senso é flexível, dinâmico, absorvendo com discernimento as influências mais diversas; por isso, está sempre aberto a um enriquecimento e a um esclarecimento daquilo que, momentaneamente, lhe é uma espécie de impressão (ARANHA, MARTINS, 1998).

É dessa forma que a interdisciplinaridade coloca, lado a lado, humildes e estudiosos, pois, anterior a qualquer tipo de estudo ou título, o que ela reconhece é o humano e tem consciência de sua contribuição insubstituível para a construção do saber e, principalmente, para a contribuição do desenvolvimento alheio.

Para entender essa nova relação, atenha-se que

A dinâmica que inspira a pesquisa consiste em uma inversão, no próprio plano da gramática, do verbo 'reconhecer' de seu uso na voz ativa para seu uso na voz passiva: eu reconheço ativamente alguma coisa, pessoas, eu próprio, eu peço para ser reconhecido por outros (RICOEUR, 2006, p.10). 
Pela interdisciplinaridade, há o reconhecimento de que cada indivíduo tem parcela importante de saber, como se detivesse uma peça de quebra-cabeça e que, junto a outras peças, oferece uma compreensão mais completa da realidade; em outras palavras, pela interdisciplinaridade, o homem é chamado à participação, a disponibilizar sua identidade e, ao mesmo tempo, exercitar a alteridade, ao ter que valorizar os que estão ao seu lado e reconhecerem-se como fabricantes da história.

Nesse ambiente de acolhida, o homem se motiva para continuar evoluindo e encontra as condições que impulsionam tal desenvolvimento. "O ativo envolvimento ou a mera exposição àquilo que os outros estão fazendo geralmente inspira a pessoa a realizar atividades semelhantes sozinha" (BRONFENBRENNER, 1996, p.7), e, principalmente, faz encontrar, neste outro ao seu lado, um companheiro disposto a encarar as mudanças que conduzem ao amadurecimento.

Considerando as diferentes perspectivas, europeia, americana e brasileira (LENOIR, 2005-2006 - LENOIR; HASNI, 2004) e antes de vê-las como conflitantes, é importante crer em sua riqueza singular e considerá-las como complementares. A atitude interdisciplinar exige uma busca por solucionar desafios que the surgem a partir de seu cotidiano e do sistema em que a pessoa está inserida, tal qual na vertente americana, além de pautar-se e sustentar-se teoricamente, tal como nos pede a visão francesa. Assim, o ponto de partida para isso é a visão única e insubstituível do professor, tal como nos prega a vertente brasileira. Cada uma traz um olhar distinto, mas também um valor acrescido quando unidas. Confirmando que:

Tomadas isoladamente ao contrário, cada perspectiva pode conduzir a
desvios. Se a abordagem instrumental pode ser um coadjuvante poderoso
para resolver problemas sociais de diversas ordens, ela pode também
reduzir a atividade intelectual a preocupações de viabilidade comercial e
submeter à formação universitária - ensino e pesquisa - às exigências
políticas ou econômicas (LENOIR, 2005-2006, p.17).

Conscientes dos desafios em se assumir uma atitude interdisciplinar, eis uma aposta vantajosa, porque essa atitude "apresenta possibilidades que antes não eram oferecidas e quando isso acontece, surge a oportunidade de revitalizar as instituições e as pessoas que nela trabalham" (FAZENDA, 2002, p.18). Como numa relação recíproca, percebemos que quando a pessoa muda, o espaço em que ela está muda também; quando a pessoa se desenvolve, o ambiente em que ela se encontra se transforma com ela, torna-se apto a ser um ambiente de desenvolvimento. Eis o que se deseja do ambiente escolar. 


\title{
3.3 A INTERDISCIPLINARIDADE NA ESCOLA
}

A interdisciplinaridade na escola apresenta-se como um valor importante por apresentar realmente uma nova forma de lidar com o conhecimento. Sem esquecer o valor singular de cada disciplina, ela solicita que esse valor individual se estenda para as outras áreas. Uma atitude que transcenda o simples saber disciplinado e que vá buscar uma integração entre esses conhecimentos.

A atitude interdisciplinar,

\begin{abstract}
Tanto nas ciências em geral quanto na educação, não põe em xeque a dimensão disciplinar do conhecimento em suas etapas de investigação, produção e socialização. O que se propõe é uma profunda revisão de pensamento, que deve caminhar no sentido da intensificação do diálogo, das trocas, da integração conceitual e metodológica nos diferentes campos do saber (THIESEN, 2008, p.4).
\end{abstract}

Também a interdisciplinaridade se faz, sobretudo, solícita ao apresentar uma transformação e uma exaltação das relações entre aqueles que direta ou indiretamente produzem o conhecimento. Produzir é o verbo inovador desta relação com o conhecimento e com o outro. Todos agora fazem parte real desse processo de elaboração do conhecimento, todos que chegam à escola levam consigo a cortesia de um presente, esse se caracteriza pelos saberes que cada um possui.

Toda essa visão altera realmente a relação professor-aluno-conhecimento. Com o passar do tempo, o mundo mudou; com as tecnologias, as fronteiras foram extintas. Se o mundo mudou, a educação também precisa mudar. "Um processo de ensino baseado na transmissão linear e parcelada da informação livresca certamente não será suficiente" (THIESEN, 2008, p.7). Quebra-se a antiga visão do professor como único detentor do saber e do aluno como um gravador a guardar cada sábia palavra de seu mestre, colocando-os lado a lado na busca pelas respostas desejadas.

Assim, uma nova atitude como essa - "nova atitude porque os conhecimentos são muito mais do que simplesmente adquiridos, eles são construídos e o projeto para a elevação de tal está contido na história de vida de cada indivíduo" (FAZENDA, 2009a, p.24) - tem como material de apoio os livros e todos os meios tecnológicos que auxiliam na divulgação do saber, mas, antes de tudo, tem como auxilio primeiro e fundamental a própria experiência individual de cada um. 
Mais do que alterar o currículo, os programas, o que se almeja transformar é a atitude da pessoa frente ao conhecimento. Quer-se passar de uma atitude passiva para uma atitude ativa, em que todos necessitam atuar com o risco de que, se a omissão ocorrer, o conhecimento receberá sua parcela de alienação. Por isso, se "os técnicos preocupam-se incessantemente em reformar os programas, sem desconfiarem de que os programas não são tudo e que não contém o essencial" (GUSDORF, 1987, p.15), a interdisciplinaridade completa essa decisiva lacuna ao introduzir o aspecto humano, ao elevar a individualidade e a diferença entre as pessoas, elemento inicial e significador do conhecimento.

Tomando posse desse conjunto de diferenças, em que todos têm importância e são aceitos por suas singularidades, a mente se alarga, as atitudes ganham significados. Com isso, o tão almejado desenvolvimento humano, que se dá pela interação com os sistemas (objetos, pessoas, símbolos), visando a uma relação positiva, tem, na interdisciplinaridade, um fator propulsor.

Isso é demasiadamente importante ao assumir que a escola é o lugar da diferença, da pluralidade e, por isso, precisa de uma forma coerente para lidar positivamente com tamanha diversidade. "A escola precisará acompanhar o ritmo das mudanças que se operam em todos os segmentos que compõem a sociedade. O mundo está cada vez mais interconectado, interdisciplinarizado e complexo" (THIESEN, 2008, p.6), e o instrumento para tanto está na atitude interdisciplinar que se caracteriza como:

o aspecto de primordial importância e mesmo como factor decisivo para a própria sobrevivência da instituição escolar. O reconhecimento do papel crucial que a Escola teve e continua a ter na origem das várias delimitações disciplinares e suas reorganizações, obriga a que, de modo paralelo, se procure agora utilizar a escola como meio de promover o desenvolvimento de atitudes, hábitos e formas de trabalhos interdisciplinares (POMBO, 1993, p.180).

Quando a atitude interdisciplinar é assumida dentro da escola, torna-se possível imaginar e, assim, buscar alternativas para que a instituição contorne as graves consequências de um ensino cada vez mais especializado, fragmentário, abstrato e, consequentemente, vazio de sentido, que a própria escola viabilize e fomente a prática de uma cada vez maior e profunda interdisciplinaridade e integração de saberes (POMBO, 1993).

Ao adotar a atitude interdisciplinar dentro do contexto escolar, as noções, as finalidades, as habilidades e as técnicas só têm pleno significado quando superam 
seu caráter puramente conteudista e avançam pelos aspectos singulares da vida de cada aprendente, permitindo que se entendam os fatores que tendem a facilitar (participação, criatividade) ou atrapalhar (descontextualização, irreflexão) o processo de aprendizagem, resultando no fortalecimento do primeiro e na diminuição do segundo, para que, a partir disso, possa-se seguir respeitando os saberes dos alunos e a sua integração (FAZENDA, 2009b).

Essa nova atitude dentro da escola, além de alterar a relação dos que ali estão com o conhecimento - buscando uma integração entre os saberes -, modifica também a relação que existe entre essas mesmas pessoas, principalmente na postura do educador, já que, como profetiza Thiesen:

Só haverá interdisciplinaridade no trabalho e na postura do educador se ele for capaz de partilhar o domínio do saber, se tiver a coragem necessária para abandonar o conforto da linguagem estritamente técnica e aventurarse num domínio que é de todos e de que, portanto, ninguém é proprietário exclusivo (THIESEN, 2008, p.8).

Uma tão ousada atitude como essa tem seu ponto de partida na decisão pessoal do docente em assumir para si, em suas ações, em seu modo de ser diante do outro e com o outro, uma atitude interdisciplinar. Entretanto, apenas a escolha por ela não basta, é preciso perseverar nesta opção, suportando e enfrentando todas as dificuldades que uma postura questionadora como essa impõe.

As dificuldades não tardam em aparecer. Uma mudança de paradigma a qual defendemos é um trabalho lento e árduo, o que por si só exige do educador uma postura decisiva de quem realmente acredita naquilo que deseja e luta por isso. Lutar até mesmo contra as concepções enraizadas em seu íntimo, pois essa nova atitude interdisciplinar há de colocar em questão a maioria dos aprendizados que fundamentaram sua formação acadêmica.

É necessário, nessa ação, que se avalie toda a formação que conduziu o professor até ali e que, a partir dessa análise, possa ser dado um novo rumo às suas ações. Isso gera um sentimento de incerteza e de insegurança muito grande, o que pode, num efeito nefasto, travar qualquer ação inovadora por parte do indivíduo.

Incerteza porque, ante as novas exigências que o ensino impõe e o atual momento em que nos encontramos, descobrimos que as crenças e as opiniões, que tudo aquilo que se aprendeu na universidade, parecem não dar conta da realidade, que há falhas naquilo em que se acredita e que durante muito tempo serviu como 
referência para pensar e agir (CHAUÍ, 2004). A base acadêmica que formou o professor parece incapaz de comportar o dia a dia no qual ele está inserido.

Consequentemente, ao não ser capaz de assumir firmemente o que se sabe, o docente encara diante de si a insegurança. Fica sem saber o que fazer, o que pensar, o que dizer dentro da situação em que se encontra. Duas opções então se Ihe apresentam: a primeira, mais tentadora e mais fácil, é a de abandonar qualquer nova proposta e qualquer inovadora postura e abrigar-se no ambiente conhecido e corroborado das práticas ultrapassadas e costumeiras. Essas podem não atender às novas necessidades do conhecimento, mas continuam a ser um lugar comum a esse professor, resgatando, ao custo de uma relação deficiente entre ele e o aluno, entre ensino e aprendizado, a pseudo-confiança então perdida.

A outra opção está em assumir suas inquietações e, a partir delas, rumar para novos saberes. Usar da avaliação que fez de si mesmo e de sua formação para buscar preencher aquilo que lhe falta. Sempre haverá uma lacuna ao docente, já que, por melhor que tenha sido sua formação acadêmica, o saber se altera e evolui constantemente e é preciso que o docente evolua com ele. O que só acontecerá se o professor se mantiver como pesquisador, conquistando novos conhecimentos e, assim, adquirindo condições de oferecer mais e melhor os resultados obtidos, e, como aprendente, mantendo viva a humildade de que nunca detém todo o saber e que a diminuição dessa inata ignorância se dá pela troca recíproca com os outros.

Por conta desse desafio em se decidir por uma atitude interdisciplinar, cuja conceituação solicita reconhecer e valorizar a atuação de todos, somos obrigados a enfatizar, em um primeiro momento, a atuação de alguns, destes poucos que optam por aventurar-se dentro de um ambiente desconhecido denominado interdisciplinaridade, que ousam superar as fronteiras limitantes de sua disciplina para, então, poderem maravilhar-se com o conhecimento alheio.

Os desafios aludidos, mais do que um elemento dramático utilizado para enaltecer aqueles que optam por assumir uma atitude interdisciplinar, são características reais e inevitáveis do cotidiano. Isso porque trabalhar com as diferenças e valorizá-las encontra obstáculo dentro da própria diferença. Essa é mãe do conflito que, por sua vez, é caminho necessário para o amadurecimento que se procura. "O conflito grupal é inevitável, pode ser manifesto ou latente, pois o grupo é formado por pessoas que diferem entre si" (LANE, 1981, p.64). 
Os bons resultados da relação ensino e aprendizagem e o positivo desenvolvimento humano, para elencarmos apenas os assuntos pertinentes a esta pesquisa, são consequências de uma superação agradável do conflito, porque

O conflito provoca mudanças internas nas pessoas e no grupo. O líder e os membros do grupo devem administrar uma condição de conflito, pois é um dos pontos fundamentais na competência interpessoal (MOSCOVICl, 1998, p.8).

Quando o conflito fica apenas como reflexo de uma querela entre duas ou mais pessoas, ele vai desestabilizar qualquer trabalho e impedir que se visualize 0 futuro, que se arrisque em um novo empreendimento. Contudo, se o modo de lidar com ele produz um amadurecimento, isso há de enaltecer os indivíduos que dele participam e, por consequência, aqueles que de forma indireta construíram a ação.

O que se quer dizer é que o conflito é algo inevitável. Parodiando a leitura bíblica, onde dois ou mais estiverem reunidos, o conflito estará no meio deles ${ }^{4}$, porque as diferenças vão confrontar ideias opostas. Daí a necessidade de valores como respeito e humildade para reconhecer qual a melhor alternativa para a questão imposta - eis um desafio não só escolar, mas de todos os ramos do conhecimento, afinal, não poucas são as histórias dos grandes pensadores que, inicialmente amigos, assumiram intensa inimizade por conta de concepções eqüidistantes.

O conflito também coloca em choque a questão da identidade, do modo de ser de cada um, pois é inegável o quanto uma postura diferente daquele que se escolhe incomoda aos indivíduos.

O viver em grupos permite o confronto, o conflito, entre as pessoas e cada um vai construindo o seu "eu" neste processo de interação, através de constatações de diferenças e semelhanças entre nós e os outros. É neste processo que desenvolvemos a individualidade, a nossa identidade social e a consciência-de-si-mesmo (LANE, 1981, p.16).

Se essas particularidades puderem ser utilizadas para se questionar o que se faz, quem se é, independentemente das respostas obtidas, haverá, junto à reflexão de si mesmo, o desenvolvimento humano.

A verdade é que a maioria das pessoas sente-se grandemente desconfortável diante daquilo que é diferente. Basta lembrar-se do sentimento que se tem quando oferecemos uma opinião sobre um determinado assunto; ao falar, e com o concordar das pessoas que conversam conosco, os ânimos aumentam, a segurança parece tomar conta do orador, mas é só alguém manifestar opinião contrária, alguém se 
postar desfavoravelmente em relação ao assunto tratado que nosso modo de agir se transforma. Os ânimos se refreiam, a segurança perde sua intensidade e uma postura tão livre que se adotava dá lugar a um agir defensivo.

Não é simples lidar com os conflitos, porém, também não é possível abandoná-los. É preciso, então, tentar superá-los, sobretudo, porque a escola é, por essência, o lugar da diferença e do conflito. Aqueles que nela estão inseridos têm a dupla missão de trabalhar e de superar os seus próprios conflitos, além de auxiliar os outros com os seus. Consciente dessa realidade é que à escola é dada a missão de preparar os alunos "para viverem e superarem as dificuldades em um mundo de mudanças rápidas e de conflitos interpessoais, contribuindo para o processo de desenvolvimento do indivíduo" (DESSEN; POLONIA, 2007, p. 25).

Essa postura se encarna principalmente no professor, cujo cotidiano oferece os conflitos habituais a toda pessoa e, antes mesmo de superá-los, tem que intermediar e amparar o conflito daqueles que se põem diante dele, os alunos. Para que possa guiar outros por esse mundo de intensas transformações e para que dentro dele se efetive o desenvolvimento humano, também o professor precisa desenvolver-se. "Retomamos novamente a necessidade de condições humanas diferenciadas no processo de interação que faça que saberes de professores numa harmonia desejada integrem-se aos saberes dos alunos" (FAZENDA, 2009a, p.27).

O docente carrega consigo inquietações, dúvidas e incertezas, que, enquanto não forem trabalhadas, impedem seu desenvolvimento e o atrapalham em seu relacionamento com os demais professores e com os alunos. Porém, é impossível esperar que ele encontre primeiro as respostas de que precisa para só depois desempenhar seu papel. É preciso a ousadia de fazer isso simultaneamente e, mais ainda, que se utilize dessas inquietações como impulso revitalizador de suas atitudes.

É preciso aceitar seus sentimentos e, a partir deles, construir uma metodologia do trabalho interdisciplinar, originando uma forma de ação cujas atitudes busquem não apenas o puro conhecimento, mas abarque a pessoa como um todo e sua vida por inteiro. As atitudes daí provenientes se apoiam na análise introspectiva pelo docente de suas práticas, de maneira a permitir-lhe reconhecer aspectos de seu ser (seu 'eu') que Ihe são desconhecidos e, a partir daí, tomar consciência de sua abordagem interdisciplinar (LENOIR, 2005-2006). 
Isso pode ser possível quando, ao assumir suas questões existenciais, o docente aceita o desafio de respondê-las, ousa aventurar-se pelo caminho desconhecido de seu próprio "eu". "As pesquisas no Brasil veem apontando para a necessidade de uma análise introspectiva do professor e de suas práticas, de maneira a fazer ressurgir de seu ser a ajuda e o auxílio que lhe são desconhecidos" (FAZENDA, 2009b, p.107).

Ao abandonar sua passividade, transformando suas dúvidas em pesquisa, 0 docente começa "a compreender que os indivíduos não aprendem apenas usando a razão, o intelecto, mas também a intuição, as sensações, as emoções e os sentimentos" (THIESEN, 2008), e, de posse desse material intelectual que está dentro dele mesmo, torna-se novamente um aprendente e, na obtenção, ainda que lenta, de suas respostas, ele obtém o valoroso reconhecimento de si (RICOEUR, 2006), tornando-se também capaz de reconhecer o outro ao seu lado. Na atuação conjunta, na troca de experiências e de conhecimento, evidencia-se um crescimento.

Porém, é preciso reconhecer que a atitude interdisciplinar voltada para a subjetividade do docente corre o risco de cair em um total relativismo; sofre a tentação de se tornar um ponto de vista desconexo da realidade, mantido apenas pela arrogância de seu pensador, pois uma alternativa que não se pauta na realidade será uma quimera, um conjunto de ideias bonitas, de frases bem ordenadas, mas incapaz de apresentar resultados. Como também um conjunto de ideias fundamentado apenas na experiência cotidiana e sem embasamento teórico não passa de senso comum, sendo incapaz de sobreviver às dificuldades e aos conflitos que a adoção de uma nova atitude suscita, tornando-se frágil ante qualquer postura distinta e a ataque de teorias contrárias.

Para evitar tal procedimento é que a participação do outro se torna ainda mais importante, para que este possa ajudar a manter as ideias dentro do ambiente e da realidade a que elas pertencem.

Some-se a essa ideia que:

A perspectiva fenomenológica, que pode favorecer enormemente a tomada de consciência pelo docente de suas funções profissionais, senão sociais, pode também induzir condutas humanas que negligenciam, entre outras, a relação com o saber (LENOIR, 2005-2006). 
Isso exige do docente o constante aprimoramento, evidencia a necessidade do aprendizado permanente, ou seja, é preciso que o professor se torne um pesquisador-aprendente.

Pesquisador, pois é necessário dar ao seu ponto de vista a coerência, a clareza e a argumentação capaz de trazer para junto de si a força daqueles que o cercam, convencer aqueles que estão a sua volta a trabalharem com ele, a acreditarem em seus projetos, pela verdade que ele traz e não pela amizade que tem com seus colegas. É ser, de novo, o que era nos tempos de graduação, um interessado pelo saber, um "amante" do conhecimento. Alguém que lê nos livros as pistas para as inovações e, principalmente, alguém que vislumbra em sua própria vida os conceitos que elucidam com maior eficácia o cotidiano em que ele e outros com quem interage se encontram.

Aprendente, porque adquire conhecimento sobre si mesmo, sobre os outros e sobre o ambiente em que se encontra; porque quanto mais busca resposta, quanto mais se apropria dos saberes, mais descobre a imensidão de conhecimento que ainda há diante de si e ao qual nunca terá acesso sozinho. O professor aprendente não se deixa dominar por qualquer falsa modéstia, ele reconhece todo seu conhecimento, sabe o quanto progrediu em relação ao conhecimento. Isso, porém, não diminui a humildade em saber que sempre haverá algo para aprender. Assim o é porque o mundo muda, porque as pessoas que estão com ele também mudam e ele, por sua vez, não é o mesmo ao longo de sua vida.

A atitude interdisciplinar baseada na subjetividade e apoiada na obtenção de novos conhecimentos por parte do docente valoriza em muito as mais diferentes formas de compreensão da realidade, além de reconhecer e de incentivar as mais variadas soluções para os problemas identificados. Isso se torna uma evolução quando retira do docente a atuação passiva, a qual se conformou nos últimos anos "Substituímos o espanto e a curiosidade pelo gesto simples da manipulação." (POMBO, 1993, p.174) -, em que passou a aceitar ideias prontas retiradas das mais diferentes bibliografias e que, por mais ricas e bem elaboradas que sejam, muitas vezes, não apresentam nenhuma relação com a realidade vigente. 


\section{DESENVOLVIMENTO HUMANO}

Toda reflexão a respeito da interdisciplinaridade alcança neste capítulo o seu ápice. Após incessante esforço em entender esse conceito, é preciso articulá-lo de forma a justificar a crença originária de que ele, inserido na escola e personificado na atitude docente, pode favorecer o desenvolvimento humano.

Tal relação se torna evidente quando se entender o outro elemento da equação. Para suprir essa necessidade e guiar o estudo do desenvolvimento humano, adotou-se a Teoria Bioecológica do Desenvolvimento Humano, elaborada por Urie Bronfenbrenner (1994, 1996, 2011), que define seu trabalho como:

O estudo científico da progressiva acomodação mútua, durante todo o ciclo
de vida, entre um ser humano ativo em crescimento e as propriedades em
mudança nos contextos imediatos os quais a pessoa em desenvolvimento
vive. Nesse processo ela é afetada pelas relações entre esse contexto
imediato e os distantes, estando todos esses encaixados $(2011$, p.138)

Com essa teoria, há a disposição em compreender a relação recíproca entre os indivíduos e os ambientes dentro dos quais o ser humano não é encarado como um receptor das características ambientais, mas antes um elemento ativo, com capacidade de intervir no seu meio e alterar as suas circunstâncias, proporcionando o desenvolvimento (DINIZ; KOLLER, 2010).

A concepção inicial de que o ambiente influi no desenvolvimento, tanto quanto a pessoa também o altera, é lugar comum nas ciências que abordam o processo de desenvolvimento. A teoria bioecológica diferencia-se delas ao alterar a própria percepção de ambiente, captando e entendendo sua influência para além dos limites do entorno imediato, com os quais cada ser trata diretamente, avançando para contextos dos quais o indivíduo não participa, mas é também influenciado por ele.

Esse multinível em que é dividido o CONTEXTO é o que dá o caráter ecológico à sua teoria; são sistemas entrelaçados, que têm como primeiro ambiente aquele que está mais próximo do sujeito, o microssistema. Definido como um padrão de atividades, papéis e relações interpessoais vividos num ambiente específico, o microssistema se torna valioso também quando se atém que é dentro dele que se operam os processos proximais, produzindo e sustentando o desenvolvimento, mas sua eficácia em implementar o desenvolvimento depende da estrutura e do conteúdo dos ambientes frequentados (BRONFENBRENNER, 2011). 
Os processos proximais constituem, nessa pesquisa de mestrado, a relação do docente com seus pares, com seus alunos e com os funcionários. Relações pautadas na atitude interdisciplinar que evidenciam a identidade de cada um desses agentes, que valorizam suas singularidades e suas histórias de vida, colocando-as a disposição do todo, que aceitam e buscam superar os conflitos naturais em meio a tanta diferença, de modo que cada pessoa positivamente se transforme e, com eles, o ambiente em que se encontram.

O segundo ambiente é o mesossistema, que se forma na inter-relação entre dois ou mais ambientes nos quais a pessoa participa. Ele apresenta certa troca de ações e de posturas entre os ambientes. "Um mesossistema é portanto um sistema de microssistemas" (BRONFENBRENNER, 1996, p.21). No caso do docente, pode ser constituído pela escola, pela família, pelo clube ou outra instituição a que pertença.

O desenvolvimento se caracteriza em muito pela presença de uma transformação positiva que acompanhe a pessoa nos vários lugares que frequenta. As características favorecidas pela atitude interdisciplinar, as mudanças operada por ela, devem transpor os limites de um único ambiente e se reproduzir em vários outros lugares, deixando entender que tal alteração, no comportamento, no pensamento ou no modo de ser da pessoa, passou a ser realmente parte dele.

O terceiro nível é chamado de exossistema e se refere aos ambientes que afetam os indivíduos mesmo não sendo eles participantes ativos de tais lugares.

inclui as ligações e processos que ocorrem entre pelo menos duas ou mais
configurações, uma das quais não contém a pessoa em desenvolvimento,
mas nos quais ocorrem eventos que indiretamente influenciam os processos
de desenvolvimento dentro do ambiente imediato no qual a pessoa vive
(BRONFENBRENNER, 1994, p.1643)

Por exemplo, o trabalho do cônjuge, a escola dos filhos, o relacionamento familiar alteram o modo como os docentes agem dentro da escola. Entender esses pormenores auxilia na apreensão dos pressupostos de cada ação, no entendimento da aceitação ou da recusa pelo novo e pela própria interdisciplinaridade

Por fim, o ambiente mais distante a influenciar a pessoa é o macrossistema. Esse nível está ligado à cultura, às crenças e às ideologias que influenciam na pessoa em desenvolvimento. Ele dá consistência a todos os outros sistemas, abrangendo a sociedade na qual os outros sistemas estão inseridos. A compreensão desse nível se dá muito pelo conjunto de leis, pela visão institucional imposta para a 
escola e pela obrigatoriedade da interdisciplinaridade contida nas resoluções governamentais.

Tais informações estão contidas principalmente no primeiro capítulo deste trabalho, quando se elaborou uma compreensão sobre a instituição escolar, sobre a sua constituição interna e sobre as forças externas (leis estaduais e federais) que a condicionam ainda que à distância.

Esses distintos, mas integrados sistemas, permitem uma compreensão mais elaborada da pessoa em desenvolvimento. Contudo, ainda restringem o foco à relação pessoa-ambiente. Bronfenbrenner ainda fez uma nova extensão à sua análise, incluindo as questões biológicas, psicológicas e comportamentais, aspectos inseridos na teoria junto aos elementos do processo, da pessoa, e do tempo que, interligados ao contexto, ficaram conhecidos como modelo PPCT.

Dentro do modelo, o estudo do contexto já havia sido ampliado e, com o aprimoramento da teoria bioecológica, o PROCESSO também foi exaltado.

A principal crítica de Bronfenbrenner com relação ao modelo original é que
este atribuía uma ênfase muito grande ao papel do ambiente durante o
desenvolvimento, conferindo menor atenção aos processos individuais. (...)
nesta nova versão, as diferentes formas de interação das pessoas não são
mais tratadas simplesmente como uma função do ambiente, mas como uma
função do processo, que é definido em termos da relação entre o ambiente
e as características da pessoa em desenvolvimento (CECCONELLO;
KOLLER, 2003, p.516).

O processo seria constituído pela inserção da pessoa em ambientes cada vez mais complexos, aos quais precisaria se adaptar, constituindo, assim, elemento decisivo para o desenvolvimento. Valorizam-se, nesse quesito, as várias interações recíprocas vivenciadas pelo sujeito diante das pessoas, dos objetos e dos símbolos existentes ao seu redor.

As diferentes formas de interação dentro do ambiente imediato são denominadas como processos proximais, que operam ao longo do tempo e são situadas como os mecanismos primários que produzem o desenvolvimento (BRONFENBRENNER, 2011). Elas carregam consigo os efeitos das atividades conjuntas, o peso e a responsabilidade imposta pelos papéis sociais, o respeito e a afetividade construída no dia a dia, fatores que podem determinar a construção identitária e desenvolvimental da pessoa.

A escola, enquanto ambiente da pesquisa, abarca em seu seio tais processos proximais, tornando-se lugar privilegiado para averiguá-los e compreendê-los. 
Justifica essa afirmação a compreensão de que a citada instituição produz todos os aspectos previstos na teoria para que eles se consolidem.

Segundo Cecconello e Koller (2003), a presença dos processos proximais e, com ele, do desenvolvimento está relacionada, em primeiro lugar, à necessidade da pessoa de estar engajada em uma atividade e isso é característico da escola, pois os que ali atuam estão centrados no processo de ensino e de aprendizagem.

Tudo isso ocorre ao longo de todo o período escolar, refletido nesta pesquisa pelo ano letivo corrente, assumindo, em segundo lugar, a concepção de que, para ser efetiva, a interação deve acontecer em uma base relativamente regular, por meio de períodos estendidos de tempo, não sendo possível ocorrer efetivamente durante atividades meramente ocasionais.

Em terceiro lugar, é preciso constar que as atividades devem ser progressivamente mais complexas, o que está de acordo com a própria organização da escola, em que cada bimestre oferece uma situação mais difícil que a anterior. Ainda na questão das interações, as pessoas que se encontram na escola estão em um ambiente mais desafiador, lidando com situações as quais não podem prever.

A situação dinâmica dentro da escola deve tornar-se recíproca no sentido de estimular a atenção, a exploração, a manipulação e a imaginação da pessoa em desenvolvimento, fator que se harmoniza com a ideia de interdisciplinaridade. Ela há de valorizar, fortalecer e ampliar as relações existentes dentro do ambiente, auxiliando a promover um amadurecimento tanto intelectual quanto psicológico.

A PESSOA a quem tanto citamos é um ser ativo, que interage constantemente com os ambientes que o cercam - representada na pesquisa pelo docente. $O$ teor dessa interação transforma tanto o indivíduo quanto o ambiente com que ele se relaciona, criando um conjunto de relações recíprocas que influenciam a forma, a força, o conteúdo e a direção dos processos proximais e, ao mesmo tempo, são resultados da interação conjunta dos elementos do contexto, da pessoa, do processo e do tempo (CECCONELLO; KOLLER, 2003). O desenvolvimento positivo se dá pelo modo como essas relações são conduzidas.

As relações existentes não se caracterizam como justas. Não há uma igualdade originária entre as forças da pessoa e do ambiente. Por isso, envolver-se com os desafios cotidianos vindos do outro, das instituições, dos objetos e dos símbolos à sua volta torna-se essencial e decisivo para que a pessoa, ao impor suas peculiaridades, vá construindo sua identidade e autonomia. 
A cada vez que ele supera tais forças e se constitui como pessoa, isso movimenta seu desenvolvimento. No dado momento em que alcança determinada estabilidade, a pessoa já se insere em um momento mais complexo do que o anterior, fazendo da mudança positiva um processo que perdura por toda a vida.

Não há ambiente que seja totalmente condicionante, a pessoa em desenvolvimento não é meramente uma tábula rasa, ela é uma entidade em crescimento, dinâmica, que progressivamente penetra no meio em que reside e o reestrutura (BRONFENBRENNER, 1996). Cada pessoa carrega dentro de si um agente transformador que se manifesta querendo ou não.

Suas ações, sejam quais forem, alteram o ambiente, o que faz com que as escolhas sejam fundamentais. A pessoa que decide oferecer suas perspectivas ao ambiente trabalha por sua transformação; outros que reprimem suas características permitem a manutenção do status quo. Em ambos os casos, o ambiente é influenciado, pois alguns auxiliam em sua modificação enquanto outros o mantém.

Todos os elementos da teoria acontecem sob a força do TEMPO. O desenvolvimento só poderá ser considerado se a pessoa apresentar seu novo eu ao longo dos dias. Esse processo de transformação que acompanha a pessoa somente se encerrará no dia em que sua história deixar de ser escrita, ou seja, com a morte.

O estudo da influência do tempo é dividido em níveis que partem do microtempo, abrangendo a atos contínuos ou descontínuos, feitos dentro do processo proximal; são as atitudes dos docentes vistas no momento em que elas acontecem. Há, depois, o mesotempo, que se refere a espaços maiores de tempo, como os dias e as semanas, dentro dos quais se busca a repetição e 0 fortalecimento das atitudes interdisciplinares. Por último, o macrotempo trata das mudanças dentro da sociedade, caracterizada pelas gerações.

A amplitude da teoria bioecológica afirma sua escolha. Seu exercício também. A pesquisa bioecológica é feita no ambiente dos participantes, dentro do cotidiano a que pertencem, evitando qualquer situação artificial, retirando as informações tal como elas se manifestam, longe de qualquer alteração - eis a busca do desenvolvimento-no-contexto. Último e decisivo aspecto a ser pesado.

Por fim, a teoria, em todas as suas características, há de amparar o estudo do desenvolvimento humano. Ela ajudará a, provisoriamente, defini-lo a fim de encontrá-lo para, então, junto dele, constatar ou não toda relação com a atitude interdisciplinar. 


\subsection{DESENVOLVIMENTO HUMANO E INTERDISCIPLINARIDADE}

A ideia de desenvolvimento se torna mais apreensível quando está posta em seu lugar de origem, o cotidiano. É dentro do dia a dia que também se constrói a atitude interdisciplinar. A partir dessa semelhança, ilustrar-se-á o desenvolvimento. Ao apresentar a atitude interdisciplinar, pode-se mostrar como ele ocorre e o que favorece a transformação positiva da pessoa.

A atitude interdisciplinar, a partir do momento em que resgata, atualiza e potencializa a identidade e os valores da pessoa e os coloca como elemento precípuo da relação recíproca com os outros e com o ambiente, apresenta-se como propulsora do desenvolvimento humano. A prática docente que eleva o subjetivo ao patamar de ciência está subsidiada por cinco princípios - humildade, coerência, espera vigiada, respeito e desapego (FAZENDA, 2002) - que carregam consigo o germe da transformação positiva, agindo sobre cada aspecto do desenvolvimento.

A transformação positiva da pessoa a que tanto se almeja está sempre relacionada ao crescimento físico, intelectual, emocional e social. Entender essa relação significa assimilar como que tais características se produzem e se modificam dentro do contexto com o qual o indivíduo se relaciona.

\footnotetext{
O desenvolvimento humano representa, assim, uma reorganização contínua dentro da unidade tempo-espaço, que opera no nível das ações, percepções, atividades e interações do indivíduo com seu mundo, sendo estimulado ou inibido por meio das interações com diferentes participantes do ambiente da pessoa (DESSEN; COSTA JUNIOR, 2005, p.11).
}

Soma-se a essa ideia a concepção de que:

O desenvolvimento humano é um processo de construção contínua que se estende ao longo da vida dos indivíduos, sendo fruto de uma organização complexa e hierarquizada que envolve desde os componentes intraorgânicos até as relações sociais e a agência humana (SIFUENTES; DESSEN; OLIVEIRA, 2007, p.379).

Amadurecer tais aspectos e lhes impor desafios cada vez mais complexos para que possam desenvolver-se positivamente é função da escola e do professor.

Para ser considerado desenvolvimento, as mudanças devem superar qualquer imediatismo e enraizar-se nas diversas ações, além de espalhar-se pelos vários ambientes frequentados pela pessoa. Em suma, o desenvolvimento envolve "uma mudança nas características da pessoa que não é nem efêmera nem ligada à 
situação, mas que implica uma reorganização que tem certa continuidade ao longo do tempo e do espaço" (BRONFENBRENNER, 1996, p.23). Sendo assim,

Para demonstrar que o desenvolvimento humano ocorreu, é necessário estabelecer que uma mudança produzida nas concepções e/ou atividades da pessoa foi transferida para outros ambientes e outros momentos. (BRONFENBRENNER, 1996, p.28).

Tal desenvolvimento está em plena consonância com os objetivos da escola, cuja preparação e resultado não estão ligados somente ao seu espaço, mas também ao mundo social, que é mais amplo que ele. Isso significa romper o tempo de aula e transcender aos limites da sala e da própria instituição, conduzindo o amadurecimento construído aos lares, aos grupos de amigos, aos encontros religiosos, dentre outros.

A escola tem o privilégio de produzir as condições para o indivíduo instituir-se como pessoa individual no meio coletivo, um "eu" entre outros "eus", um ser em um contexto com o qual deve obrigatoriamente se relacionar, encontrando um meio de inserir nesse mundo sua capacidade autônoma, responsável, apta a agir na sociedade de maneira refletida e livre.

Dentro do ambiente escolar, cada pessoa experimenta desafios existentes em toda a sociedade e, ao buscar ajustar-se aos diferentes ambientes de que participa, ao tentar superar as dificuldades de um mundo de mudanças rápidas e de conflitos interpessoais, efetiva cada vez mais seu desenvolvimento.

Ao executar tal ação, ao dispor sua singularidade ao outro e ao acolher o que a sociedade the oferece, nessa conflituosa relação, habita o desenvolvimento, ou seja, o homem é fruto de uma sociedade, é imagem ligada a uma determinada realidade, mas, ao mesmo tempo, o homem também altera essa realidade. $O$ desenvolvimento se dá nessa relação recíproca, pois nenhuma realidade é totalmente condicionante e cabe ao homem, a todo o momento, impor sua visão.

As ideias que permitem compreender e efetivar o desenvolvimento humano podem ser claras a um adulto. Os anos de experiências, as diferentes vivências, as situações particulares que enfrentou lhe dão bagagem suficiente para entender e para assumir suas responsabilidades dentro da construção de sua própria identidade e de sua própria vida. Contudo, aos mais novos, representados na escola pelos alunos, que carregam consigo a imaturidade e até mesmo a ingenuidade própria da 
idade, é preciso dedicar atenção especial e auxílio. Essa é tarefa também da escola e, principalmente, do professor.

O conhecimento construído entre professor e aluno deve clarear a vida desses novos indivíduos, auxiliando-os nos desafios comuns a qualquer existência, possibilitando entender a dificuldade em desenvolver-se, em se construir como pessoa, em partilhar sua identidade e em realizar seus projetos. Todos esses fatores, que derivam da relação com o mundo, não acontecem de maneira simples; exigem esforço, perseverança, vontade de cada pessoa, além do conhecimento para encontrar o melhor caminho que o ligue a seus objetivos.

Frente ao desafio de desenvolver-se, assumindo uma atitude interdisciplinar, o professor se torna parceiro a caminhar lado a lado com o aluno e modelo na busca de respostas às diversas indagações. Apesar de o aluno apresentar questões diferentes das do professor, esse jovem, ao reconhecer no docente alguém em constante aprimoramento, encontra nele o exemplo a ser seguido. Mais do que isso, reconhece nele as atitudes necessárias para superar suas próprias dificuldades.

O docente não será mais nem apenas aquele que ordena e impõe uma tarefa que ele mesmo não realiza; ao contrário, ele passa a ser o condutor de seus alunos a fim de apresentar-Ihes o espaço, talvez incômodo, dos saberes, mostrando na prática a desafiante, e quase sempre árdua, arte de se construir conhecimento. Aos poucos, respeitando a maturidade própria de cada idade, passa a atuar ao lado deles, auxiliando no que precisarem e também solicitando a ajuda e a participação deles. O professor será realmente exemplo de conquistas e de desenvolvimento pessoal tanto quanto da necessidade de se dividir as responsabilidades, as descobertas; atitude que conduz a resultados sempre maiores do que aqueles obtidos pelo esforço unicamente pessoal.

Esse aspecto conceitual soa como ação perfeita, como atitude louvável e inquestionável devido às suas qualidades e possíveis resultados. Porém, fala-se da relação entre as pessoas e essas são cheias de conflitos. Há resistência em ambos os lados, pois, "cada um desenvolve a maior habilidade para evitar ver-se face a face, evitar questionar suas razões de ser, que, na maioria das vezes, são ausências da razão" (GUSDORF, 1987, p.142). O desejo pelo bem não supera as dificuldades que existem na construção de ligações entre vidas distintas. Há fatores ocultos na história de cada um que dificulta a interação e os afasta mutuamente. 
Consciente dessa dificuldade, a atitude interdisciplinar docente tende a privilegiar e expandir seus princípios com o objetivo de criar aberturas em meio às barreiras construídas pelos indivíduos. São ideais que, se vividos, podem favorecer a aproximação entre as pessoas, de forma que o resultado seja benéfico para ambos os lados.

O professor não realiza essa construção sozinho, ele tende a ser o motivador desses princípios. Ele assume ser o semeador de tais atitudes e, para que esses princípios realmente frutifiquem, ele os completa a partir do seu modo de ser frente e junto desses que dividem com ele o espaço escolar.

É dessa forma que Ivani Fazenda aponta cinco princípios que subsidiam a prática docente interdisciplinar, sendo eles a humildade, a coerência, a espera vigiada, o respeito e o desapego (2002). Sem ordem específica, o que se encontra nesses princípios são caminhos para elevar a convivência e retirar dela os aspectos que favorecem o mútuo desenvolvimento.

Somam-se a eles outros valores dignificantes da pessoa e propulsores do desenvolvimento, tais como o diálogo, a alteridade, o reconhecimento e a reciprocidade. Elementos que, se presentes no dia a dia social, se constantes nas relações dentro da escola, retiram o que há de mais positivo nas pessoas, gerando nelas uma transformação realmente positiva.

Os princípios da interdisciplinaridade e os valores dignificantes da pessoa não são colocados simplesmente lado a lado, eles se relacionam, interagem entre si de modo que cada um favoreça o outro, de maneira que ambos se potencializem em prol do ser humano.

De posse de tamanha revelação, busca-se a "Coerência" em realizar com maestria aquilo que a teoria tão bem aceita. No desejo de assumir uma postura coerente, capaz de refletir a junção entre teoria e prática, pode-se entender esse aspecto da seguinte maneira:

\footnotetext{
O mesmo que compatibilidade. Esse significado é assumido com freqüência por esse termo em italiano e em francês, pois nessas línguas o termo compatibilidade não se presta a exprimir o caráter do sistema desprovido de contradição, mas designa o caráter de não-contradição recíproca dos enunciados (ABBAGNANO, 2007, p.172).
}

Refletir sobre a vida e, dentro dela, sobre os processos que conduzem ao desenvolvimento é meditar irremediavelmente sobre as contradições. Cada pessoa manifesta, em suas ações e palavras, essa inconstância. Por isso, a coerência não 
está ligada à necessidade de o homem agir sempre e constantemente da mesma forma, está, ao contrário, na aceitação dessa mudança, na interpretação positiva que ela pode oferecer, afinal, o homem é um ser em constante transformação e, sendo assim, é preciso que o professor reconheça isso no outro e em si mesmo e assuma a responsabilidade de construir, com o outro, caminhos que levem à boa condução dessa transformação.

Da mesma maneira que os outros princípios da interdisciplinaridade (humildade, espera vigiada, respeito e desapego), a coerência se constrói dentro da própria vivência do professor. A origem da Coerência está no esforço docente em transformar qualitativamente suas atitudes, demonstrando por meio delas todos os desejos que anseia despertar em seus alunos.

Pela Coerência o professor dá vida aos seus ensinamentos, ofertando como exemplo sua própria vida. Os grandes pensadores, os famosos cientistas, os aclamados desbravadores, cujos nomes estão impressos na história e cuja face está estampada nos livros, serão sempre bons exemplos, mas nada supera a proximidade do professor, que pode realizar frente aos outros e com os outros essa tão desejada nova forma de produzir conhecimento.

Para que isso se realize, para chegar à Coerência

é preciso se conhecer e conceder-se a capacidade de mudar, estar aberto ao outro, aos outros, numa osmose singular, pois coerência não significa que as ideias são imutáveis. Faz-se necessário permitir-se permitindo, num processo de espera vigiada constante, enriquecido pelo olhar de amor intencional, que se exprime, que reconhece e é reconhecido, um olhar capaz de transcender o próprio olho (GIACON, 2002, p. 37).

Em suma, a coerência há de subsidiar a vivência de outros valores, há de auxiliar que aquilo que é descrito e aceito como belo e importante dentro das relações humanas seja realmente vivenciado, superando, para isso, toda dificuldade que existe dentro dessas mesmas relações. A coerência permitiria manter, aos olhos de todos, os motivos que impulsionam o exercício dos valores propostos, aceitandoos como desafiadores, como árduos em sua realização, mas de grande valia na busca pelo desenvolvimento humano.

Assim, na construção dessa coerência unificadora da teoria e da prática, que valoriza e potencializa o eu e o outro em desenvolvimento, apresenta-se a oportunidade do diálogo, mediado pelo princípio da humildade. 


\subsection{HUMILDADE E DIÁLOGO}

Dos princípios que subsidiam a atitude interdisciplinar docente, a "Humildade" tem a primazia, pois ela articula e possibilita as demais. Essa virtude abre as portas para o outro e toma a iniciativa ao convidar a todos para uma relação construtiva, capaz de proporcionar as diversas experiências que conduzem ao desenvolvimento positivo do homem. O docente no exercício da humildade dá o primeiro passo para fugir dos preconceitos existentes e dos temores que dificultam as relações humanas.

Em todo encontro, "cada uma das duas partes presentes se acha exposta ao perigo que a outra oferece, pois todo encontro nos desloca e nos recompõe" (GUSDORF, 1987). Entretanto, o professor, ao vivenciar sua humildade diante dos outros (professores, funcionários, alunos) quebra barreiras, cria atalhos, aceita o desafio de elevar a interação existente a um patamar muito maior do que aquele baseado no oferecimento de conteúdos disciplinares, ele possibilita a interação entre duas ou mais vidas, entre experiências reais e saberes que estão muito adiante daquele encontrado nos livros, pois foram certificados pela própria vida cotidiana.

Por isso se diz que a humildade é uma mescla de ignorância e de sabedoria. $\mathrm{Na}$ atitude interdisciplinar, ela é expressa pela consciência de suas qualidades e pelo reconhecimento de suas deficiências. "Não é depreciação de si nem falsa apreciação. Não é ignorância do que somos, mas conhecimento, ou reconhecimento do que não somos." (ALVES, 2002, p. 61). É também a aceitação de que o mundo é muito maior e mais complexo do que a simples razão individual pode apreender e que, por isso, uma visão elaborada desta realidade só pode ser construída e aproximar-se efetivamente da verdade quando realizada conjuntamente.

Identificar essa limitação pessoal frente à realidade, aceitar a ignorância inerente à espécie humana é o quesito fundamental para diminuir sua influência junto ao indivíduo. É só pelo exercício da humildade que a ignorância dá lugar, por exemplo, ao espanto e à admiração, sentimentos que fazem querer saber o que não se sabe, que fazem querer sair do estado de insegurança ou de encantamento, levando a perceber a ignorância e criando o desejo de superar a incerteza em busca das grandes verdades (CHAUÍ, 2004).

Verdades que conduzem a pessoa ao desenvolvimento e seu efeito é distribuído, querendo ou não, entre aqueles com quem interage. 


\begin{abstract}
Se um dos membros do par passa por um processo de desenvolvimento, 0 outro também passa. O reconhecimento desta relação proporciona uma chave para a compreensão das mudanças desenvolvimentais não apenas nas crianças, mas também nos adultos que servem como cuidadores primários - mães, pais, avós, professores e assim por diante. A mesma consideração se aplica a díades envolvendo marido e mulher, irmão e irmã, chefe e empregado, amigos ou colegas de trabalhos (BRONFENBRENNER, 1996, p.7)
\end{abstract}

Com isso, há de se entender que cada pessoa, ao confinar-se num mundo próprio, torna-se um alienado e, por melhor que possa se desenvolver sozinho, os resultados nunca se aproximam aos daqueles que se dispõe a enfrentar o desafio do convívio e da ação conjunta.

O simples fato de conviver lado a lado já oferece ao outro a oportunidade de desenvolvimento. "Sempre que uma pessoa em um ambiente presta atenção às atividades de uma outra pessoa, ou delas participa, existe uma relação" (BRONFENBRENNER, 1996, p.46). O outro questiona com seu modo de ser, colocando a identidade alheia em xeque; suas ideias espalham dúvidas sobre as concepções construídas, necessitando atualizá-las a todo instante; suas ações servem de parâmetro para que o outro se estimule à realizações tão eficazes e, ao superar esses desafios, a pessoa se encontra num estágio melhor do que o anterior.

Seguindo esse raciocínio, ao entender, aceitar e valorizar a influente interação entre os indivíduos, pode-se crer que a humildade permite ao docente a ação diferenciada e engrandecedora do diálogo. Isso, por si só, é uma mudança de paradigma, já que o lugar comum mostra que "ensino reduz-se a um monólogo que, na prática, se desdobra - o monólogo do professor tem seu eco no monólogo do aluno que recita sua lição" (GUSDORF, 1987, p.27). Ao docente interdisciplinar, essa mudança do monólogo para o diálogo é essencial.

O novo está na efetiva aceitação de que o conhecimento se constrói. O que somente é feito quando cada participante encontra a liberdade e o apoio para oferecer sua visão. Isso só pode acontecer quando o professor se destitui da posição de único regente do conhecimento e divide a responsabilidade com todos. $O$ docente não deixa de lado sua autoridade, nem deixa de manter certa hierarquia (ele ainda é o professor), o que ocorre é que, a partir de então, todos participam ativamente da elaboração do saber e cabe ao professor, com sua experiência, conduzir essa construção, e o instrumento maior para tanto é o "Diálogo". 
Há no diálogo precípuas questões. O diálogo a que nos reportamos tem suas bases no filósofo grego Sócrates. Para ele, essa arte trazia consigo fatores como a igualdade e o reconhecimento por aceitar que a verdade habita em todos, precisando alguns apenas de auxílio para que essa venha a nascer. Daí que a maiêutica socrática ${ }^{5}$ pode ser, ainda hoje, fonte de inspiração a tantos docentes, já que permite a troca mútua, a resultar na compreensão dos mais variados assuntos.

Sendo troca, significa que a pessoa oferece seu conhecimento ao outro da mesma forma que o recebe. O que tem a oferecer de mais valioso é o conhecimento de si mesmo, sua identidade. Assim, há, no diálogo, uma efetiva apropriação da sentença do oráculo de Delfos ${ }^{6}$ "conhece-te a ti mesmo", e é, na posse provisória dessa informação, que o homem ocupa seu lugar no debate.

$\mathrm{O}$ ato de conhecer-se a si mesmo coloca a pessoa

De encontro com as raízes comuns que nos ligam aos nossos semelhantes e ao ambiente em que vivemos, objetos da nossa busca de conhecimento. Essa relação entre autoconhecimento e cultura é fundamental no sentido de que conhecer no outro é reconhecer em si. É também um ato de se redimensionar pessoalmente com e a partir deste co-nascimento. Cultura e autoconhecimento permitirão que cheguemos à condição de seres humanos, à consciência de ser (TAINO, 2008, p.1).

$\mathrm{Na}$ construção da identidade, na árdua tarefa de constituir-se como pessoa, todo homem tem seus pontos fracos; percebê-los representa a possibilidade de superá-los, e o diálogo é o instrumento para isso. O impulso necessário a qualquer processo de mudança não é somente exterior ao homem, mas está também nele, levando-o a sobrepor seus limites. Pelo diálogo, há o humilde ato de reconhecimento mútuo entre os que dele participam.

A discussão do mestre e do discípulo [e também da escola com a família, com a sociedade] revela assim que qualquer verdade humana é uma verdade em diálogo; o sentido da verdade é o que está em jogo num debate em que cada um, enfrentando o outro, enfrenta-se a si mesmo e mede-se com a verdade, com a sua verdade (GUSDORF, 1987, p.135).

É nesse ponto que o diálogo se diferencia da simples conversa. Nesta existe uma espécie de disputa pelo ouvido alheio, o outro é apenas um depositário de ideias, não existe menor interesse pela ideia alheia, o falante impõe ao outro o fardo de unicamente escutar e deixa-se tomar por maus sentimentos quando contrariado ou interrompido; esse outro, quando saturado por tamanho esforço, interrompe, invertendo a situação, mas não a alterando qualitativamente. 
Pelo diálogo, devido a sua relação de equidade, é dada a todos a oportunidade de falar enquanto ensina-os a também ouvir. Os que desejam participar são acolhidos e reconhecidos em sua importância, são insubstituíveis em seu ponto de vista. Por isso, cada saber partilhado é valorizado, influenciando positivamente na construção e na consolidação da autoestima e da identidade.

Com isso, criam-se elementos facilitadores para que a pessoa se adapte às novas circunstâncias e para que enfrente as adversidades, os conflitos e os problemas de maneira positiva e construtiva, tornando-se competente e bem integrado, estabelecendo relações acolhedoras e afetuosas, conscientes de suas conquistas, de seus fracassos e projetos, com uma atitude vital ativa, otimista, voltada para o futuro, com autonomia e autoestima elevada (FIERRO, 2004). São esses elementos facilitadores que impulsionam o desenvolvimento.

No decorrer da vida, produzem-se numerosas mudanças que provocam crises no equilíbrio que buscamos. Essas crises, que podem as vezes refletir ou ser interpretadas como uma instabilidade, como uma certa desestruturação, são também motores de reorganização pessoal, de transformação, que permitem novas adaptações e evolução" (SALVADOR, 1999 p.191).

O docente tem a sensibilidade de entender tal momento e, assim, dispor-se a ajudar nesse processo de adaptação. A humildade está, então, em oferecer-se sem necessitar que o outro the chame ou indague. O olhar atento do professor, que, pelo diálogo conhece a vida de seus alunos e companheiros, está atento para seguir lado a lado com esse, demonstrando-Ihe o valor dessa mudança.

Mudança traduzida por Gusdorf como:

motor da transformação do homem: ao tomar consciência de sua situação na sociedade e no tempo, descobre exigências fundamentais de sua existência e, ao obedecer, conformar-se ou submeter-se, acaba por negar o seu direito a escolha, ao exercício da vontade própria. Mudar não é deixarse levar como um navio à deriva: é se autogovernar em meio às circunstâncias, às tempestades, exercitando, de forma consciente, as possibilidades (In: RAMOS, 2002, p.69).

A humildade não necessita que o outro se humilhe para que a atitude de ajuda aconteça, ao contrário, ela aguça a percepção daqueles que a praticam, de forma que estão preparados, não importa o momento, para entrar em ação. Até porque há a consciência de que a mudança não é unilateral, esse docente, apto a ajudar, também necessita de ajuda, já que também está em constante mudança. 


\subsection{RESPEITO E ALTERIDADE}

A humildade que permite o diálogo prepara cada pessoa para reconhecer o valor do outro em sua formação. Este outro permite que o "eu" conheça um mundo diferente, que também é o seu mundo, mas cujos aspectos fogem aos seus olhos. $O$ confronto com essas idiossincrasias gera questões e conflitos, tanto internos quanto externos, que se bem articulados geram resultados positivos.

Diante do outro, do diferente, é que a identidade se constrói, tal como as ideias, pois esse outro apresenta oportunidades de abandonar certas visões quando aceitas como errôneas ou superadas e também de reafirmar tantas outras, valendose da crença de que estão corretas. Disso, pode-se crer que:

\footnotetext{
Viver o encontro é descobrir-se a si mesmo para descobrir o outro, é comunicar-se. É estabelecer uma parceria com vida, é estar em sintonia, envolver-se e deixar ser envolvido. É viver na própria afetividade sendo presença, acolhendo o outro para um renascer com-junto em meio à diversidade das singularidades (RANGHETTI, 2002, p.87).
}

Em ambos os aspectos, o indivíduo muda para melhor, pois, se aceita o novo, significa que se atualiza, que expande seu conhecimento ao assumir algo mais correto do que tinha anteriormente. Se por ventura, mantém sua postura e seu conceito inicial, também nesse momento há a transformação, pois é preciso que, para se reafirmar, encontre motivos novos e mais concretos que lhe amparem e sustentem ante aquele que é diferente.

Por isso, a humildade é tida como primeiro princípio da atitude interdisciplinar (FAZENDA, 2002). Ela reconhece a influência recíproca que gera as relações e as amplia. Melhor, aponta e evidencia nela os elementos que podem favorecer ao desenvolvimento, o que, numa relação, nunca é particular. "Se um membro de uma díade sofre uma mudança desenvolvimental, é provável que o outro também mude" (BRONFENBRENNER, 1996, p.53).

Dado que os processos de mudança são partilhados, a humildade se transforma em "Respeito", atuando no reconhecimento alheio, na valorização do outro sem perder a confiança e a aceitação de si mesmo, ou seja, sem degenerar em uma falsa modéstia. Assim, o respeito torna-se elemento preparatório do espírito humano para a criação e a manutenção de parcerias. 
A parceria que se estabelece com os sujeitos entre si e com o conhecimento histórico e socialmente construído é fundamental na prática interdisciplinar. Surge de um movimento revelador dos aspectos ocultos dos atos de ensinar e aprender que se processam por meio da reflexão na e sobre a prática cotidiana (JUSTINA, 2002, p.161).

Para que a parceria seja uma constante, é preciso ressaltar a ideia de ensinar e aprender. No diálogo, ambas as ações estão presentes. "No encontro, duas existências revelam-se uma à outra e cada uma a si mesma, pois só nos descobrimos verdadeiramente no choque e na prova da presença de outrem" (GUSDORF, 1987, p.143). Todos os homens têm algo a ensinar, têm participação importante na vida alheia, ao mesmo tempo, todos também têm muito que aprender, têm uma série de limites que só podem ser superados com a ajuda do outro.

De forma mais elaborada, Ford e Lerner explicam o valor dessa interação:

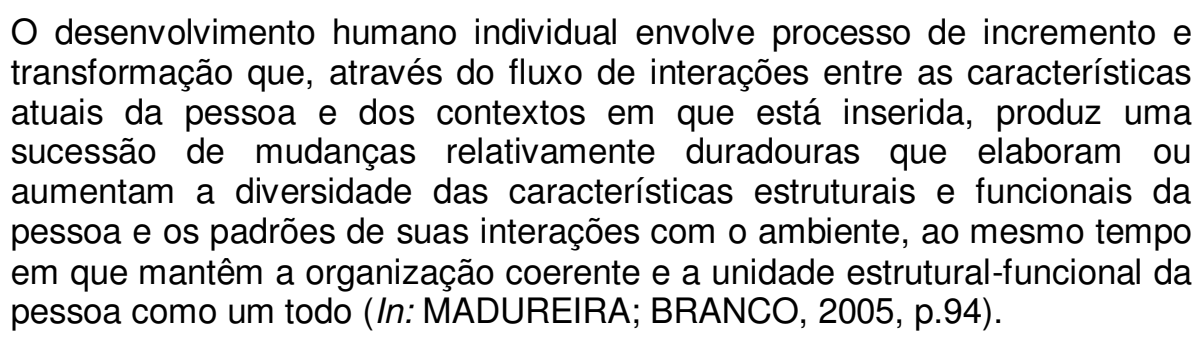

O homem é um ser social, inevitavelmente se relaciona com o outro e, acima de qualquer vontade sua, sofre a influência de quem está ao seu redor tanto quanto os influencia. O modo como essa relação é conduzida pode gerar fatores positivos para as pessoas, tornando-se, por exemplo, fatores de proteção, os quais "referemse a influências que modificam, melhoram ou alteram respostas pessoais a determinados riscos de desadaptação" (POLETTO; KOLLER, 2008, p.409).

Não basta, portanto, viver lado a lado, é preciso transformar a presença de muitos em um conviver capaz de salientar cada característica pessoal, além de respeitar e de valorizar a individualidade alheia. Quando há essa abertura ao outro, reconhecendo-o, institui-se e fortalece a "Alteridade".

Por alteridade "entende-se o outro absolutamente outro, não passível de intelecção, de compreensão. É o que não se enquadra ou não se adapta ao sistema englobante da razão estando sempre situada fora da totalidade" (OLIVEIRA; SCORALICK, 2008, p.33), ou seja, o outro está sempre além da razão, por isso, é insubstituível, sua contribuição é sempre indispensável.

A alteridade cria a liberdade de ser, diante do outro, aquilo que se é. Eis um dos motivos de sua importante participação na adoção de uma atitude 
interdisciplinar e na construção de ambientes propulsores de desenvolvimento humano. A alteridade auxilia a transformar um ambiente hostil em um lugar aconchegante, capaz de acolher o indivíduo por aquilo que ele é e de aceitar seus defeitos tanto quanto suas qualidades, de aceitar suas particularidades tanto quanto seus elementos em comum.

Sentir-se bem no ambiente em que se encontra, principalmente no ambiente de aprendizagem que se constitui a escola, ser aceito e valorizado como ser que pensa, sente, conhece, apresenta-se como alicerce de uma relação educativa em que a afetividade se faz presente (RANGHETTI, 2002). Isso, além de motivar e ampliar as possibilidades de aquisição de conhecimento, ajuda a instaurar e a manter a autoestima, de modo que outros fatores também venham à tona.

É o caso da criatividade, que vem a ser a construção de algo novo, que foge ao normal, é a capacidade de gerar novos projetos, produtos ou ideias e de, com isso, o novo constantemente intervir no desenvolvimento. Porém, para que essa oportunidade do diferente aconteça, é preciso que o indivíduo criativo encontre aceitação e espaço para sua produção. A criatividade,

concebida a partir da construção de algo novo [...] As atividades
combinatórias estão relacionadas com a habilidade humana de lidar com a
mudança. Na combinação, as impressões são associadas a novas
situações e a novos comportamentos. Tanto as atividades criativas
reprodutivas como as combinatórias são dependentes da acumulação de
experiências. Este é um processo lento de maturação interna, iniado a
partir da internalização de percepções externas (CHAGAS; ASPESI;
FLEITH, 2005, p.214).

Ela tem seu limite no saber individual. Toda construção, seja lugar comum ou inovadora, só pode ser realizada a partir dos conhecimentos tidos pela pessoa. A criatividade, então, torna-se manifestação da articulação e da força de transformação que o individual é capaz de fazer com aquilo que conhece. Por isso, a criatividade não está aquém do convívio social, nem tão pouco do desenvolvimento humano.

Ela transita entre os aspectos pessoais e sociais e, de certa forma, os liga. No aspecto pessoal, está o oferecimento do ponto de vista individual da pessoa. A criatividade manifesta sua ótica única e insubstituível a respeito de inúmeras coisas. Assim, uma obra de arte, um texto, uma canção, dentre outras coisas, é a maneira que a pessoa encontra de apresentar-se ao mundo e de participar dele. 
No aspecto social, encontra-se a influência do outro sobre o indivíduo. Cada elemento exterior ao homem insere-se nele como um fator condicionante. Lidar com esta pressão requer força e determinação, contudo, por mais que se neguem as influências exteriores, elas sempre deixam sua marca. Por isso, afirma-se que ninguém é independente do contexto sociocultural em que se encontra inserido, mas também não é mero reflexo desse contexto: o indivíduo mantém uma relação de relativa autonomia com ele (MADUREIRA; BRANCO, 2005).

A criatividade auxilia assim na mudança do indivíduo. "Mudar é romper as amarras, quebrar couraças e agir de forma mais livre, numa racionalidade aberta, sem apegar-se a velhos mitos ou teorias superadas" (RAMOS, 2002, p.72). Para seguir além do que está estabelecido, é preciso, em muitos casos, criar alternativas para alcançar aquilo que se deseja.

Como o desafio de formar-se persegue o homem em toda a sua história, a criatividade precisa acompanhá-lo sempre, ela é um instrumento necessário, principalmente, ao desenvolvimento humano, pois se o homem é sempre um ser em transição, ele precisa de auxílio para preparar também o mundo para receber sua individualidade, ele precisa da criatividade.

criatividade não pode ser vista como algo cristalizado e estático, que ocorre
em um determinado momento, mas, ao contrário, deve ser entendida como
um processo dinâmico e contínuo. Portanto, não é possível entender o
indivíduo criativo e o seu processo de criação sem levar em consideração
as múltiplas dimensões do desenvolvimento humano (CHAGAS; ASPESI;
FLEITH, 2005, p.211).

A criatividade é apenas um dos exemplos do quanto o respeito e a alteridade podem favorecer o desenvolvimento. Para que ela exista e se amplie, é preciso um ambiente propício e a escola precisa ser esse ambiente. A elevação a esse patamar pode ser guiada pela atitude interdisciplinar, pois, em sua ação diferenciada tanto com seus pares quanto diante do aluno e com o aluno, o docente pode favorecer um clima de encorajamento e de suporte para o desempenho desses.

Isso significa dar relativa autonomia à medida que são estabelecidas regras claras e acordadas com os alunos, evitando atitudes autoritárias e controladoras, (CHAGAS; ASPESI; FLEITH, 2005), valendo também ao professor. Ambos, professor e aluno, se encontrariam encorajados a arriscar mais, a desvencilhar-se do medo de errar e a participar ativamente de seu processo de desenvolvimento. 


\subsection{DESAPEGO E RECIPROCIDADE}

Diante do desejo de que os fatores anteriormente discutidos se efetivem e para que o constante desenvolvimento pelo qual passa a pessoa possa encontrar elementos que Ihe facilitem, é preciso também o desapego. Este significa a abertura constante à mudança, ao novo, à atualização. É por essa disposição ao novo que o desapego se justifica entre os princípios da interdisciplinaridade (FAZENDA, 2002).

Com a ajuda dele, a

Interdisciplinaridade compreende a busca constante de novos caminhos,
outras realidades, novos desafios, a ousadia da busca e do construir. É ir
além da mera observação, mesmo que as realidades do cotidiano teimem
em nos colocar perplexos e inseguros diante do desconhecido ou
estimulando a indiferença para evitar maiores compromissos (SOUZA,
2002, p.120).

Para tanto, ao contrário do que se pensa, o desapego não é nunca o negar-se do passado, mas sim o desejo constante de evolução. Por isso, ele se vale da humildade ao saber que o caminho da evolução é constante e que o tempo das transformações é inseparável ao tempo em que se vive. Ele se utiliza do respeito ao passado, às experiências anteriores, à memória, mas sempre os utilizando como impulsão ao futuro. Traz consigo a espera vigiada, como que reconhecendo que a cada nova etapa os desafios aumentam e tornam-se cada vez mais decisivos, para o que é preciso refletir antes de qualquer decisão.

O desapego significa desprender-se dos preconceitos com relação ao novo, por mais assustador que uma nova visão possa ser. Assustador, no sentido de que os homens se sentem desconfortáveis diante do inédito, da incerteza e das inúmeras variáveis que o desconhecido apresenta, colocando em situação difícil a segurança adquirida pelas experiências passadas. É como se o passado, por pior que tenha sido, fizesse mais sentido, ou melhor, é que sobre as coisas do passado o homem tem certo domínio de suas atitudes. Porém, é preciso superar esse receio e aventurar-se por novos horizontes.

O docente não pode questionar seu aluno quanto a uma nova perspectiva se ele próprio não se relaciona com o futuro. O primeiro a dar esse passo rumo à mudança, que sempre há de ser incerta, é o professor. "Para socorrer verdadeiramente alguém, observa Kierkegaard, devo estar melhor informado que ele 
e, antes de tudo, ter a inteligência do que ele compreende, sem o que a minha qualidade de mestre não Ihe será de nenhum proveito" (GUSDORF, 1987, p.140). O docente, em sua atitude interdisciplinar, está na vanguarda dessas reações, chamando e incentivando aqueles que desejam alcançá-lo.

Apenas quando o docente interdisciplinar e a escola em si se desligarem do comodismo que acompanha o passado e assumirem a ousadia da inovação é que se iniciará a construção de um ambiente capaz de promover efetivamente o desenvolvimento humano.

A antiga visão de escola está vinculada à atrofiada percepção da pura divulgação do conhecimento. Porém, a instituição em questão abriga pessoas, cada uma com sua história, com sua identidade, cheia de valores e de desejos, que nascem e se reforçam fora das paredes da escola. Quando as pessoas adentram o recinto, é impossível focarem-se totalmente nas atividades propostas. Não é mais permitido ignorar tais aspectos. Para facilitar o desenvolvimento humano, é preciso entender e assumir os elementos em questão.

Assumindo essa interpretação multifacetada das pessoas que a compõem, aceitando que cada uma traz para dentro da escola situações e sentimentos ocorridos em sistemas diferentes e distantes do microssistema escolar, apontamos o ponto propedêutico para uma relação baseada na "Reciprocidade". A escola apresenta seu corpo teórico de conhecimento, oferece aos seus toda base científica atual e recebe em troca a experiência, a vida de cada um que compõem seu interior, dos docentes aos alunos. O resultado dessa troca se dá num conhecimento significativo, que abrange todas as características da pessoa, a intelectual, a social, a emocional e a psicológica. Consequentemente, faz com que as ações adotadas tornem o local um espaço de desenvolvimento.

A escola consciente da complexidade daqueles que a formam passa a participar diretamente da regulação da atenção, das emoções, dos comportamentos e, é claro, da aprendizagem. Nesse contexto, cada pessoa vivencia inúmeras situações: relação entre pares, grupos, amizade, competição, rivalidade, aprendizagem e descoberta do novo, entre tantas outras. Diante de tudo isso, a escola pode promover a autoestima e a auto-eficácia, capacitando a todos em habilidades sociais, além de influenciar o relacionamento entre o grupo de iguais por meio de normas, de regras e da cultura da própria instituição (POLETTO; KOLLER, 2008). 
Tornar real todas as transformações sugeridas até aqui não é algo fácil. Os desafios em adotar novos rumos são tão grandes e cheios de obstáculos. Há, em inúmeros momentos, o sentimento de insegurança, a incerteza quanto ao sucesso e quanto à efetividade das ações, que se não forem bem trabalhados pelo professor, se não forem superados com coragem, confiança e ousadia podem dominar aqueles que decidem pela interdisciplinaridade, degenerando no desejo de abandonar sua nova atitude e retornar aos moldes antigos. Com as antigas ações, havia ao menos a falsa segurança de que conheciam os procedimentos, ainda que esses estivessem defasados e fossem falhos.

Mesmo com tanto receio, é preciso continuar. Saint-Exupery alertava, "a vida do passado parece corresponder melhor à nossa natureza apenas porque corresponde melhor à nossa linguagem" (1981, p.38), por isso, para superar tanto medo é que se constrói, com a ajuda de todos, orientados pela atitude interdisciplinar, uma nova linguagem.

O alicerce que sustenta esse desapego e a adoção de uma atitude interdisciplinar por parte do docente se constrói também com a reciprocidade. $O$ professor que oferece seu "eu", sua identidade aos outros, ainda que o faça desinteressadamente, tomado apenas pela responsabilidade daquele que participa ativamente do local em que se encontra e, mais ainda, que atua diretamente na história das pessoas que estão ao seu lado, ainda que a gratuidade conduza tais relações, o docente sempre há de receber algo em troca. Como uma ordem natural, a reciprocidade, de diversas formas, vai lhe ofertar amparo ante os desafios do novo e o incentivo para continuar nesse rumo inovador.

Com o aluno, por exemplo, o docente interdisciplinar vai encontrar um parceiro, um companheiro na construção de novos saberes. Quando o professor une ao conhecimento sua experiência, dando sentido à teoria e ao mesmo tempo abre espaço para a participação dos discentes, esses o surpreendem, devolvendo visões e ideias, ainda que pouco articuladas, as quais escapavam aos olhos do professor, ampliando assim também sua condição de análise do mundo. Na relação recíproca entre professor e aluno, há a troca de saberes, mas, principalmente, existe a troca de experiências, de vida. É um se dispondo ao outro numa relação desenvolvente de todos.

Quando, por sua vez, o olhar se volta para a relação recíproca entre os professores, a conquista se dá na propagação e na corroboração da atitude 
interdisciplinar. O docente, junto a seus pares, encontra força e apoio para seguir acreditando na mudança, encontra alternativas quando o novo parece obscuro e duvidoso. A reciprocidade reforça as parcerias, valoriza o trabalho em equipe, convida os professores a trocarem ideias e vivências, despertando o sentimento de pertença e compromisso de todos.

Por fim, pela reciprocidade também o ambiente escolar se torna outro. Não é nova a ideia de que a relação entre a pessoa e seu ambiente é uma relação recíproca. Tendo como base essa máxima, pode-se reconhecer que o professor, ao se tornar interdisciplinar, ao assumir atitudes interdisciplinares, também torna a escola assim. Nesse sentido, tal local passa a ser um ambiente preocupado com a formação integral da pessoa, valorizando a construção e a propagação do conhecimento intelectual, mas sem se limitar a ele, avançando para todas as outras questões que envolvem a vida daqueles que atuam dentro de seu espaço.

$\mathrm{Na}$ relação recíproca e transformadora gerada pela atitude interdisciplinar docente e a escola, o objetivo da instituição - em particular do Ensino Médio ganha ares de realidade, pois a escola está atenta à formação que permite a continuidade do estudo ao mesmo tempo em que se mantém ciente dos interesses dos alunos e da necessidade deles em ingressar no mercado de trabalho, deixando cada um apto a exercer qualquer futura função. Transcende até mesmo esses dois quesitos, pois o estudo e o trabalho são aspectos pertencentes a algo maior que é a vida humana. Assim, a escola, consequentemente, atém-se aos aspectos biológicos, psicológicos e sociais dos seus. Na somatória de todas essas características, a escola que se faz interdisciplinar pela atuação diferenciada de seus docentes também se faz um local de desenvolvimento humano.

De várias maneiras, as relações baseadas na reciprocidade acontecem. 0 professor, em sua atitude de oferta, também recebe. O desapego, esse esvaziamento racional (no sentido de que o professor avalia seu trabalho, sua postura, sua experiência de modo a separar o que é ultrapassado daquilo que ainda pode ser feito. O desapego não apaga a história de cada um, ele apenas auxilia a abandonar alguns pontos e fortalecer e atualizar outros), abre espaço ao novo, mas o que é inédito ainda não está pronto, é preciso, então, paciência e vontade, respeitando o tempo de corroboração desse emergente propósito. É necessário a espera vigiada e o reconhecimento de tudo o que foi e está sendo feito. 


\subsection{ESPERA E RECONHECIMENTO}

Alterar um espaço corroborado pelo tempo como é o caso da instituição escolar e as atitudes daqueles que atuam dentro dele, como é o caso dos docentes, não é tarefa que aconteça do dia para a noite. Todo esse processo de mudança é lento. Cada avanço é tomado, frequentemente, por um retrocesso. A queda é parte constituinte do caminhar por veredas desconhecidas. Por isso, a espera e a paciência são valiosas.

O tempo de espera é fator importante tanto na transformação do ambiente quanto da pessoa em desenvolvimento. Em ambos, as mudanças precisam se concretizar pela repetição. Dado que só se reconhece algo como relacionado ao desenvolvimento humano quando este supera qualquer característica efêmera.

No caso da pessoa, é preciso averiguar se as mudanças obtidas se reproduzem ao longo do tempo. A escola é um bom ambiente para verificar tal ação devido ao tempo em que cada um passa dentro desse ambiente. Mais importante do que isso, é buscar saber se cada mudança chega até outros ambientes frequentados pela pessoa.

Para melhor entender a espera vigiada dentro do processo de desenvolvimento humano, pode-se exemplificá-la a partir de dois aspectos: o primeiro, ao relacioná-la ao comportamento e às atitudes dentro da escola; o segundo, ao direcioná-la ao aprendizado.

Quando se relaciona a espera vigiada ao comportamento e às escolhas de cada pessoa, significa que se entende todo o processo que conduz ao amadurecimento. Cada ação tem sua reação, cada escolha oferece sua consequência, as escolhas corretas, ao trazer bons resultados, tendem a ser repetidas, também quando são reconhecidas atitudes valorosas pelo professor, por exemplo, o reforço frente a essa ação acontece.

O oposto também vale. Ao se realizar atitudes duvidosas, ao se constatar o erro, as ações sobre esse fato devem enfraquecê-lo, de modo que seja abandonado e trocado por outra opção melhor. Em ambos os casos, a mudança que leva ao amadurecimento ocorre, tal como diria Aristóteles (1987), por meio da repetição, que torna a ação um hábito, uma virtude ${ }^{7}$. 
Quando a espera vigiada preenche a atuação docente, esta se manifesta na compreensão de que a transformação e o aprendizado são diferentes para cada pessoa. O tempo exigido para a clarificação e a compreensão de conceitos, da fortificação da identidade, varia entre os indivíduos. Até mesmo porque tanto o aprendizado quanto a identidade são influenciados também por aspectos que ocorrem longe da ação docente, seja em casa ou na rua, e com os quais o professor precisa lidar. Por isso que, na educação, a espera precisa ser uma constante.

O professor, a professora sabe, não importa o grau de especialização ou o
nível de ensino, que o aluno, a aluna, precisa de tempo, tempo de
ESPERA/amadurecimento para introjetar conhecimentos, torná-los seus,
fazendo uso adequado daquilo que se ensinou, tornando-o parte integrante
de seu cotidiano e de seus projetos de vida (CASCINO, 2002, p.109, grifo
do autor).

O professor precisa reconhecer na sua atuação o tempo da revelação, o Kayrós $^{8}$, que valida cada experiência, cada momento e que assume que cada ação dentro da história de vida humana tem um período diferente. Assim, com extrema atenção, o docente deve seguir pelo caminho da instrução, oferecendo desafios cada vez maiores a seus alunos tanto quanto deve estar atento ao momento de amadurecimento em que este jovem se encontra, de forma a saber partilhar com ele experiências de vida, tal como deseja partilhar o conhecimento que tem.

A vivência de um tempo criativo enfatiza a atenção para as duas dimensões
da temporalidade - a primeira representada por Cronos, em que temos a
consciência da passagem do tempo, marcada pelos milênios, séculos, anos,
meses, dias, horas, minutos e segundos, em que dois aspectos podem ser
apreendidos: um de valor quantitativo nos dá uma medida, por exemplo
trinta anos, e outro de valor qualitativo, que nos permite atribuir ao tempo a
qualidade que marcou o vivido. A segunda dimensão do tempo é
representada por Kairós e nos dá o momento mágico em que a qualidade
do existir no mundo pode ser transmutada em busca da criação de uma
nova maneira de viver a vida. Cronos e Kairós precisam ser respeitados e
considerados na vida escolar, para que se possa, num processo de
articulação entre essas duas dimensões, ressignificar a maneira de viver o
tempo (QUELUZ, 2002, p.141).

Explicando melhor, o Cronos $^{9}$ equivale aos conhecimentos adquiridos com 0 passar do tempo. Ele pode ser mensurado, medido por meio de avaliações e de atividades. É todo conhecimento na forma de conteúdo que a pessoa adquire e acumula ao longo de sua vida. Porém, existe um aspecto negativo acompanhando a ideia de Cronos. Existem pessoas com enorme conhecimento, mas que não conseguem articulá-los com seu dia a dia, que não conseguem manipulá-los para além de sua utilização disciplinar ou científica. É o caso dos que se tornam 
alienados dentro de seu conhecimento específico - esses se tornam exímios profissionais, sabem conduzir seus afazeres de forma magistral, contudo, tornam-se desligados do mundo, da vida social; mesmo com tanto conhecimento, não percebem suas próprias necessidades existenciais e as daqueles que o cercam.

Já o Kairós retrata o significado dado ao conjunto de saberes que se adquire ao longo da vida. É a experiência daquele que enfim encontra amadurecimento, respeito, conhecimento de si e do outro, de modo que realmente pertença ao mundo e ao tempo em que se encontra. A escola, assim guiada, cria seu tempo próprio. Não perde sua noção de ensinar e de auxiliar o aluno em sua busca profissional, mas passa a interessar ao professor, antes de tudo, a formação humana e essa transcende o tempo cronológico de sala de aula, interessado apenas no conteúdo.

A atitude interdisciplinar absorve essas duas medidas de tempo, a cronológica e a da revelação, dando à segunda um valor maior, entendendo que o saber só tem sentido se confrontado com as dúvidas e as inquietações dadas pelas experiências de vida. Contudo, ainda que se coloque ênfase em um frente ao outro é imprescindível reconhecer o valor de ambos. O docente interdisciplinar precisa buscar realizar em sua atitude a interação do Cronos e do Kairós.

Com o primeiro, o professor traz para si todo o conhecimento que se manifesta ao longo de sua história: seus estudos, suas pesquisas e os dados obtidos pela experiência, tudo isso compõe seu conjunto conceitual, porém, isoladamente, o Cronos transforma-se em fardo a ser carregado inutilmente. É nesse sentido que Unamuno (1953) afirma: conhecer por conhecer é inumano. Com o segundo, o docente desfaz essa separação entre conhecimento e realidade, utilizando de todo o conjunto conceitual obtido para construir respostas que atendam aos seus questionamentos, sejam eles referentes a seu mundo profissional ou pessoal. Entretanto, se o professor ficar apenas nos domínios do Kairós, ele só constrói o senso comum.

É preciso então uni-los, pois, juntos, Cronos e Kairós se sustentam. Um assimila todo conhecimento necessário para a pessoa enquanto o outro dá sentido a esse saber, ligando-o à vida da própria pessoa. O Kairós, enquanto vai dando significado ao conhecimento, vai despertando novas questões que só podem ser respondidas com a ajuda do Cronos, formando um ciclo que auxilia na evolução da pessoa. Todavia, isso requer a "espera", já que o momento do Kairós é diferente para cada pessoa. 
Essa espera pela transformação positiva das pessoas não pode ser entendida de maneira passiva. A pessoa em constante desenvolvimento é sinônimo de ação, de movimento, o que não permite a inanição de uma espera mágica, em que as coisas aconteceriam por força da natureza. A espera é sempre vigiada. A vigia se dá na preparação para que tudo aconteça, criam-se os momentos, as situações para a mudança. Trabalha-se para que o ambiente proporcione as situações em que as relações existam e se comprovem como benéficas para todos.

O importante é que cada atitude permita incentivar e acolher a transformação positiva. O essencial é que a espera pelo tempo de amadurecimento de cada um seja feito enquanto se busca tal amadurecimento. Alguns, por diferentes motivos (estilo de vida, condições familiares, econômicas, sociais...), mudam qualitativamente mais rápido do que outros. O que não significa que são melhores, significa apenas que o mundo que se revela a todos encontrou primeiro naquela pessoa as condições para uma relação que há de se expandir a todos.

Todos, cada um a seu tempo, encontrarão o Kairós, a revelação do mundo, do eu, dos outros. Até que esse tempo alcance a todos, é preciso fazer constantemente justiça. Essa se faz pelo "Reconhecimento". É tornar evidente o avanço de cada um, é tornar visível a conquista obtida desde as mais simples até as mais elaboradas; é valorizar o que se construiu de modo que os primeiros passos sirvam de incentivo para o restante do caminhar.

A atitude interdisciplinar, com seus princípios propostos por Fazenda (2002), somada a certos valores em sua inteireza conceitual parece uma bela utopia, alcançá-la apresenta-se como tarefa impossível. Nossas escolas e professores estão tão impregnados em antigos hábitos, tão encarcerados em defasados afazeres, que vislumbrar o novo é quase impensável.

Contudo, a construção do todo se dá pelas primeiras etapas. A conquista por algo maior acontece por conta das pequenas vitórias obtidas no dia a dia. São essas singelas atitudes cotidianas que se unindo umas as outras apresentam o fenômeno maior da interdisciplinaridade. É nesse sentido que se faz precípuo o reconhecimento. É saber enaltecer o desejo de mudança, é saber vislumbrar os primeiros gestos que dão concretude a tal desejo, é vivenciar as alegrias e as dificuldades de uma nova postura, é saber que sempre há quem nos apóie, sustente e incentive em nossa aposta. O reconhecimento mostra os passos dados, revela as parcerias, e isso já é fruto da interdisciplinaridade, que conduz ao desenvolvimento. 


\section{$\begin{array}{llllll}\text { 4.6 A ATITUDE INTERDISCIPLINAR COMO PROPULSORA DO } & \text { A }\end{array}$ DESENVOLVIMENTO HUMANO}

Após toda essa reflexão, fica evidente que, em sua relação com o meio, o homem transforma-se constantemente, ele nunca é o mesmo nos diferentes tempos de sua vida; por isso, a análise destes âmbitos de interação possibilita acesso a oportunidades de crescimento, aos movimentos de estabilidade e de instabilidade dos contextos nos quais as pessoas estão inseridas, às interações afetivas e às relações de poder na dinâmica interpessoal (SALVADOR, 1999).

Ao longo do curso de vida, o desenvolvimento humano acontece por intermédio de processos e de interações recíprocas e, progressivamente, mais complexas entre um organismo humano ativo, em evolução biopsicológica, e pessoas, objetos e símbolos no seu ambiente externo imediato (DESSEN; COSTA JUNIOR, 2005).

Um dos responsáveis por caminhar lado a lado com o homem, unindo forças a fim de superar os desafios e as eventuais dificuldades em desenvolver-se, é a escola. A escola, assim como a família, é um dos ambientes importantíssimos na trajetória do desenvolvimento humano. Ela

...constitui um contexto diversificado de desenvolvimento e aprendizagem,
isto é, um local que reúne diversidade de conhecimentos, atividades, regras
e valores e que é permeado por conflitos, problemas e diferenças
(MAHONEY, apud DESSEN; POLONIA, 2007, p.25).

Em meio a busca para a superação dos desafios que ali se apresentam, o sujeito vai construindo e impondo sua identidade, vai sendo alterado pelo ambiente ao mesmo tempo que o altera; nessa relação mútua, identifica-se a possibilidade de desenvolvimento.

Quando a escola reconhece essa missão e, principalmente, quando deseja aproximar desenvolvimento e aprendizagem, isso requer uma atitude diferente, emerge daí a necessidade de uma atitude interdisciplinar. Essa atitude é muito mais do que um conceito, é o caminho de amadurecimento diante de uma nova forma de conhecimento que necessita, antes de qualquer teoria, de uma mudança de postura, de um replanejar do próprio ser abrindo-se aos conhecimentos externos. 
Uma nova atitude da escola só pode ocorrer quando aqueles que a compõem aceitam o desafio de promovê-lo. Dentro desse desafio, destaca-se o professor. A atuação deste pode favorecer a construção de um espaço capaz de apresentar os elementos que conduzam o indivíduo ao desenvolvimento. Para uma missão tão especial, é preciso uma atuação diferenciada, cuja ação pode estar baseada na interdisciplinaridade, pois

\footnotetext{
Além do desenvolvimento de novos saberes, a interdisciplinaridade via educação favorece novas formas de aproximação da realidade social e novas leituras das dimensões socioculturais das comunidades humanas (FAZENDA, 2005, p.14).
}

Dessa forma, o professor, ao unir os princípios da interdisciplinaridade com valores capazes de enaltecer a pessoa, adquire instrumentos que permitem 0 enobrecimento e o engrandecimento de si próprio e do outro ao seu redor, pois a interdisciplinaridade motiva o amadurecimento pessoal e é inevitável que os resultados dessa nova atitude alcancem e também modifiquem todos que então compõe o cotidiano escolar, consequentemente, transformando o próprio ambiente em que se encontram.

Em outras palavras, quando a coerência ganha espaço na atitude docente, unindo significativamente teoria e prática, conceito e vida, então a interdisciplinaridade começa. Ela segue vivenciada na humildade que prepara para a busca de novos conhecimentos, ciente de que para isso necessita de um trabalho coletivo, mediado pelo diálogo. Quando inúmeras cabeças se propõem a trabalhar juntas, é preciso respeito pelo diferente, é preciso alteridade, valorizando cada opinião, escolhendo e melhorando a que está mais perto da verdade.

Toda essa atitude nova não ocorre do dia para a noite, exige uma preparação pessoal para aceitação, o que se dá pelo desapego a qualquer dogmatismo, abrindo-se para aquilo que se apresenta como melhor. O que não significa uma aceitação passiva de ideias alheias, sendo muito mais uma troca, uma relação recíproca, em que todos ofertam e recebem, todos contribuem para a construção do saber. Vale ressaltar que os resultados dessa transformação não se apresentam rapidamente, "seria inútil plantar um carvalho na esperança de ter, em breve, o abrigo de suas folhas" (SAINT-EXUPERY, 1981, p.24), por isso, a interdisciplinaridade se vale da espera vigiada, preparando todos os fatores, atentos a todos os elementos necessários para o desenvolvimento de todos, reconhecendo, 
a cada momento, tudo o que foi alcançado e valorizando-o como passo importante para a efetivação do projeto maior que é o desenvolvimento humano.

Essa perspectiva reaviva e posiciona-se diante da afirmação de Bronfenbrenner, "Se você deseja compreender a relação entre a pessoa em desenvolvimento e algum aspecto de seu meio ambiente, tente mexer num deles e ver o que acontece com o outro" (1996, p.30), assumindo que a transformação humana e institucional tenha como epicentro o professor em sua prática cotidiana.

Aqueles docentes que assumem a responsabilidade e o compromisso de sobreporem à função pura e atrofiada de simplesmente impor conhecimento, acrescentando à sua atividade a busca e construção de um sentido existencial ao momento partilhado dentro da escola, principalmente com o aluno, são chamados por Gusdorf de Mestres. "Essa palavra consagra, agora, uma qualificação especial, uma força superior de validade, de cuja presença e irradiação irão se beneficiar todos os que com ela contactam" (GUSDORF, 1987, p.3).

O termo professor, durante os últimos anos, desenvolveu um sentido separador, elevou-se dentro dessa palavra um obstáculo a separar o docente do aluno. A relação existente entre eles se pautava apenas na obrigação do professor em ensinar e a do aluno em aprender. Sob a tutela da atitude interdisciplinar, essas barreiras se rompem, o aprendizado se dá com as questões científicas, assim como com as indagações existenciais relacionando um com o outro.

O professor interdisciplinar é intitulado "mestre" por unir ambos os conhecimentos, tanto os teóricos vindo dos livros quanto os práticos retirados da experiência diária, mas, principalmente, ele merece esse título por saber juntar vidas. Ele se dispõe aos outros, acolhe a todos e, dessa frutuosa relação, constrói o saber, as respostas, que são necessárias para ambos.

Isso ocorre, pois o docente há de evidenciar as ligações entre o conhecimento e a vida cotidiana, evitando, assim, um problema comum dentro das escolas: "a descontinuidade existente entre a escola e a experiência vivida pelos alunos fora dela não só prejudica como constitui barreira para uma inclusão e aprendizagem mais efetiva" (POLONIA; SENNA, 2005, p.195). É justamente esta interação, esta relação recíproca geradora de mudanças que deve ser entendida para que possa ser vivenciada com qualidade. 
Nessa ação, nessa condição que o docente assume de apontar desconhecidas e decisivas ligações entre a vida e o conhecer é que ele recupera parte de sua dignidade perdida.

O papel do mestre é, aqui, como o do intercessor; é ele que dá forma humana aos valores. A criança e o adolescente, todos aqueles que estão a procura de si mesmo, acham-se, assim confrontados com uma encarnação das vontades que talvez estejam adormecidas neles. E esse reencontro com o melhor, esse confronto com a mais alta exigência, desmascarando uma identidade que a si mesma se ignorava, permite a personalidade passar ao ato e escolher-se a si mesma tal como sempre desejou (GUSDORF, 1987, p.3).

As palavras acima são decisivas. Não há o simples oferecimento das coisas, elas não são dadas prontas. Há, sim, o "confronto" e ainda, "com a mais alta exigência" de forma que o aluno, diante do professor/mestre encontre-se numa situação nova, até desconfortável, diante da qual precisará buscar novos instrumentos para dar um passo além do habitual, o que irá conduzi-lo a um desenvolvimento.

O desenvolvimento humano é o processo por meio do qual a pessoa que se
desenvolve (sic) adquire uma concepção mais ampliada, diferenciada e
válida do meio ambiente ecológico, e se torna mais motivada e mais capaz
de se envolver em atividades que revelam suas propriedades, sustentam ou
reestruturam aquele ambiente em níveis de complexidade semelhante ou
maior de forma e conteúdo (POLONIA; DESSEN; SILVA, 2005, p.73).

Isso é significativo quando se entende que tais novos saberes não são dados, mas sim construídos por todos. O ponto de partida para isso é a própria vida, rica em sua subjetividade, efervescente em seus questionamentos.

A interdisciplinaridade, então, pode se apresentar como um elemento capaz de oferecer esse fator positivo, já que é naturalmente dela conceitos como diálogo, alteridade, criatividade, reciprocidade - fatores que valorizam o indivíduo como ele é e o convidam a colocar sua rica singularidade à disposição do outro. Esse oferecimento que se faz ao próximo, que vem carregado de conflitos, faz com que a pessoa encontre os meios para seu desenvolvimento.

Esses valores podem ser encontrados nos princípios que norteiam a atitude interdisciplinar. A humildade, o respeito, a espera, o desapego e a coerência despertam as ações que transformam o ambiente escolar em um espaço de convivência, de partilha, enfim, um lugar de vida. Os valores intrínsecos à interdisciplinaridade são propulsores de desenvolvimento humano ao expandir não só o conhecimento, mas também ao promover a pessoa por completo. 
O diálogo, a alteridade, o respeito ligam as pessoas e esse vínculo é produtivo, pois cria mais do que uma relação hierárquica entre as pessoas, ela produz o afeto. Esse é o que garante o desenvolvimento humano ao assegurar na continuidade da transformação positiva ao longo de várias fases que compõem o ciclo de vida e poderá ser considerado o principal componente de superação da mudança, ao longo do desenvolvimento (DINIZ; KOLLER, 2010, p.65).

Vida representa dúvidas e incertezas que acompanham a todos por toda sua história. Seja professor ou aluno, ambos têm suas inquietações. A atitude interdisciplinar permite que eles, a partir do diálogo, construam coletivamente as respostas de que precisam. Um trabalho como esse não é fácil. Criar conhecimento exige paciência, necessita saber lidar com erros e fracassos, o que para muitos são palavras proibidas.

Seguir em frente e perseverar na construção do novo e na criação de possibilidades de desenvolvimento ocorre quando existe a confiança no docente. Esse como exemplo a ser seguido, como verdadeiro mestre, como um disseminador da atitude interdisciplinar garante aos outros o entusiasmo necessário pela ação do afeto. Por esse sentimento, barreiras são superadas com mais facilidade e dificuldades são relevadas.

O afeto fortalece e amplia as relações, ele intensifica os processos de desenvolvimento, que se caracterizam pelo estabelecimento de uma interação recíproca, progressivamente mais complexa, entre um organismo humano ativo e as pessoas e os objetos do seu ambiente imediato, em que ambas as partes se mantém ativas e se estimulam mutuamente (BRONFENBRENNER, 1996).

Essa proximidade é vivida pelo docente interdisciplinar quando ele se mostra interessado não apenas pelo resultado obtido pelo aluno, mas se interessa pelo que esse a seu cuidado é enquanto pessoa, por isso se afirma que sua atuação, dotada de atitudes interdisciplinares, é produtora de desenvolvimento humano.

A atitude interdisciplinar docente, que se faz pela humildade e se abre ao diálogo, que fortifica o respeito e completa-o com a alteridade, cujo ensinamento passa pelo desapego e pela reciprocidade, que valoriza e orienta a espera enquanto reconhece tudo o que foi conquistado, revela com coerência o ser de cada pessoa.

É o docente que se mostra a partir de sua visão e da compreensão das teorias, do local e das pessoas com quem atua; é o outro, aluno ou funcionário, que também aparece, pois se nos dirigimos a eles é porque os reconhecemos capazes 
de nos entender e tanto quanto falamos também ouvimos, cientes de que esses com quem confabulamos também têm algo importante a nos dizer. A simples ação de falar e de ouvir, de reconhecer e de aceitar faz viver a equidade, criando a oportunidade a todos de apresentar seus ricos pensamentos. Quando isso ocorre, ao obter reconhecimento e aceitação, o desenvolvimento acontece. 


\section{CAMINHOS PARA A PESQUISA}

Toda a base teórica construída neste trabalho ambicionava elevar uma crença ao patamar de conhecimento científico. Tamanho intento consistia em dar clareza à ideia, fundamentá-la em argumentos consistentes, ampliá-la em suas possibilidades e, então, corroborá-la dentro da própria realidade.

O conjunto teórico elaborado atingiu todos os pontos que dele se esperava, exceto um, o de "corroborá-la dentro da realidade". Essa ação estava além das características de um simples trabalho conceitual, exigindo, assim, uma etapa complementar, em que as ideias fossem retiradas de seu habitat natural, o cotidiano.

Sendo esse um trabalho de Filosofia ou de qualquer uma das ciências sociais, sua primeira etapa talvez lhe fosse meritoriamente suficiente, contudo, é um trabalho interdisciplinar e há outras áreas do saber com quem almeja dialogar; para que ter sua atenção, é necessário ater-se aos seus métodos, é preciso dar-lhes sinais que reconheçam, é preciso ofertar-lhes a linguagem da experiência.

Inúmeros métodos ofertariam as informações desejadas, porém, era preciso escolher um que estivesse em consonância com todo o amparo conceitual, que respeitasse as características de uma pesquisa que unisse interdisciplinaridade e teoria bioecologica e que valorizasse suas congruências: a primeira reconhece o constituído, almejando sempre o inédito, o que amplia o saber; a segunda segue rompendo os limites da pura corroboração de hipóteses ao se atentar ao inesperado, ao conhecimento que se situa além das expectativas do pesquisador, seguindo, ambas, ao novo. Uma se faz pela relação entre saberes, assim como a outra se elabora pelo conhecimento da relação entre diversos os sistemas e a pessoa.

As duas se valem da subjetividade. Para a primeira, a visão particular do professor, cheia de angústias e conquistas é o ponto de partida para a construção de novos saberes; para a segunda, é mais importante o modo como as coisas são percebidas em detrimento ao que elas possam ser de fato. Em ambos os casos, a visão particular conduz à mudança, solicita a transformação.

Sob todos esses aspectos, a escolha pelo método recaiu sobre a Inserção Ecológica (CECONELLO; KOLLER, 2003 - PRATI; COUTO; MOURA; POLETTO; KOLLER, 2008 - POLETTO; KOLLER, 2008). Essa opção esclarece ao mesmo tempo em que se clarificam o problema e o objetivo que compõem a pesquisa. 


\subsection{PROBLEMA}

O "mestrado em Desenvolvimento Humano: Formação, Políticas e Práticas Sociais", dentro do qual essa pesquisa se encontra e participa, carrega em suas bases dois importantes conceitos: interdisciplinaridade e desenvolvimento humano. Ambos foram acolhidos e tornaram-se diretamente 0 alicerce e o motivo deste trabalho.

Quanto mais se debruçava sobre tais ideias e se dispunha a entendê-las, mais se reforçava a hipótese de que havia uma relação entre ambas, de que a interdisciplinaridade, vivida cotidianamente pelo docente, na forma concreta de atitudes interdisciplinares, poderia auxiliar e promover o desenvolvimento, tanto do professor - foco desta pesquisa - quanto dos que estão com ele.

A crença nessa ideia transformou-se, então, em hipótese e foi o problema dessa pesquisa: investigar se havia e como se davam as manifestações da atitude interdisciplinar na prática docente e como tais proporcionavam (ou não) o desenvolvimento humano no contexto do Ensino Médio.

Há uma explicação plausível pela escolha da etapa última da educação básica. Um trabalho cujo foco está na prática docente poderia envolver a todos os que desempenham a função de professor. Porém, uma maior atenção, uma preocupação em investigar cada detalhe que possa manifestar a atitude interdisciplinar e suas positivas consequências exige recortes típicos de uma pesquisa de mestrado (dada a impossibilidade de se atender a todas as possibilidades em um único trabalho); por isso, o contexto particular em que habita a pesquisa é o Ensino Médio.

Quando esses pormenores se tornaram evidentes, foi preciso ainda mais uma lapidação, que consistia em transformar o problema em objetivo de pesquisa e, com isso, evidenciar aquilo que tanto se procura. Essa etapa, aparentemente tão simples, mostrou-se demasiada importante, pois, como diriam à Alice no país das maravilhas: se você não sabe para onde quer ir, então, qualquer caminho serve (CARROLL, 1998). Sendo assim, somente após a elaboração do objetivo, cada nova etapa, cada instrumento de pesquisa foi se impondo como um passo após outro para se chegar ao destino desejado. 


\subsection{OBJETIVOS}

\subsubsection{Objetivo Geral}

Investigar as manifestações da atitude interdisciplinar na prática docente e suas relações com o desenvolvimento humano no contexto do Ensino Médio de uma escola pública.

\subsubsection{Objetivos Específicos}

- Identificar no exercício da docência a presença dos princípios necessários à atitude interdisciplinar e seu processo de desenvolvimento;

- Conhecer e analisar o significado de atitude interdisciplinar no espaço do trabalho para os docentes e para a escola;

- Discutir a questão da atitude interdisciplinar na prática docente e suas relações com o desenvolvimento humano-no-contexto;

- Contribuir com o contexto escolar na (re) construção dos valores humanos essenciais à sociedade contemporânea.

\subsection{RELEVÂNCIA DO ESTUDO}

A relevância deste estudo está refletida nos próprios conceitos que o sustentam: interdisciplinaridade e desenvolvimento humano. Um trabalho isolado sobre cada um deles já seria um trabalho importante, capaz de contribuir para a ampliação e o esclarecimento de ambos.

Ao limitar a pesquisa à questão da interdisciplinaridade, ela seria, ainda assim, relevante, porque, sendo a interdisciplinaridade um conceito em construção, ela foge a qualquer ideia cristalizada e se abre às novas perspectivas, às inéditas 
definições, que nascem da visão única de cada pesquisador que seriamente se debruça sobre o assunto. Essa contribuição é natural à própria ideia de interdisciplinaridade, é quase algo "necessário" (que acontece mesmo sem a vontade/liberdade) e cuja ausência condenará o conceito à incompletude.

Assim, por exemplo, uma simples revisão de literatura torna-se algo original, pois, nas palavras que ligam cada conceito, nas interpretações e nas explicações que o pesquisador faz das ideias adotadas, torna-se impossível oferecê-las de forma igual, pois ele já tomou posse dessas ideias e as alterou, ampliando-as a partir de sua vivência e de sua realidade; dotando-as, com isso, de uma verdade insubstituível, por isso relevante.

Por outro lado, tratar na pesquisa apenas do desenvolvimento humano também seria significativo. Cada pessoa é um ser inapreensível, ou seja, há sempre algo no homem que nos escapa, que está além de qualquer pesquisa, e, mesmo aquela que atingiu altos índices de saturação, encontra sua exceção, encontra aquele que foge à regra.

É exatamente essa grandeza da pessoa, essa impossibilidade de se esgotar seus mistérios em uma única pesquisa que faz dos trabalhos sobre a pessoa e sobre o desenvolvimento artigos precípuos. Cada um desses apresenta um aspecto, aponta uma manifestação da pessoa, e, ainda que se juntassem todos os trabalhos elaborados e os costurassem num todo conceitual, ainda assim, faltaria algo, pois, no mínimo, o homem de quem se fala já é outro ao final das pesquisas, o que impõe sempre uma nova reflexão sobre ela.

Se, com tudo isso, tais justificativas não forem suficientes, pode-se dizer também que este tema é relevante ao buscar valorizar a prática docente guiada pela atitude interdisciplinar, possivelmente favorecendo o processo de desenvolvimento humano. Mais do que isso, concomitantemente ao tempo da pesquisa, vai o pesquisador iniciar, incentivar e fortalecer as atitudes interdisciplinares dentro do ambiente da pesquisa. Sua valia, então, justifica-se ao tornar o pesquisador um mobilizador dessa troca de conhecimentos e experiências e, ao valorizá-la no contexto escolar, pode possibilitar as primeiras mudanças rumo a uma efetiva atitude interdisciplinar e ao favorecimento do desenvolvimento humano. 


\section{MÉTODO}

Cada nova etapa dessa pesquisa aumentava em desafio. Era inevitável pensar que um trabalho como esse nunca mais poderia ser refeito em sua inteireza, ampliando todos os cuidados em sua execução. Assim o é, porque o foco desse trabalho não está em simples reagentes químicos, nem tão pouco em elementos facilmente mensuráveis e, desse modo, permissivos de repetição, o que dá sentido e razão ao trabalho são as pessoas e suas atitudes, e isso é sempre peculiar.

Mesmo que em tempos outros se reunissem os mesmos participantes sob a tutela do mesmo pesquisador, no idêntico ambiente em que atualmente se encontram, os resultados seriam outros, pois cada pessoa, seguindo todo o processo de desenvolvimento, seria diferente, seguiria pressupostos diferentes, assim como o próprio pesquisador seria outro, com interesses e interpretações já distintas da anterior. É a voz de Heráclito ecoando, "Para os que entram nos mesmos rios, correm outras e novas águas" (1993, p.36). Pessoas estão constantemente se alterando, assim, os resultados poderiam ser semelhantes, mas nunca idênticos.

Contudo, ainda que as águas desse rio sejam outras a cada vez que nela se penetra, mesmo que as pessoas que fazem tal percurso sejam diferentes a cada travessia, ao menos os passos seguidos por elas podem ser reproduzidos. A ação de atravessar o rio pode ser refeita pela mesma pessoa ou por outros. Essa reprodução detalhada de uma ação ou de um experimento é o papel do método dentro dessa pesquisa. Descartes assim o explica:

\footnotetext{
Por método, entendo as regras certas e fáceis, graças às quais todos os que as observam exatamente jamais tomarão com verdadeiro aquilo que é falso e chegarão, sem se cansar com esforços inúteis, ao conhecimento verdadeiro do que pretendem alcançar (JAPIASSU; MARCONDES, 2006, p.187).
}

Há elementos importantes que podem ser refeitos e verificados por aqueles interessados. São procedimentos e instrumentos escolhidos atenciosamente a fim de oferecerem o conhecimento necessário para investigar as manifestações desejadas, diminuindo ao máximo o risco de se confundir ou de se perder entre as muitas possibilidades geradas pelas pessoas e suas atitudes.

Nesta pesquisa, esta etapa se distingue por informações tais como: tipo de pesquisa, campo da pesquisa, participantes, coleta e análise de dados. 


\subsection{TIPO DE PESQUISA}

A pesquisa caracteriza-se por sua natureza qualitativa, escolhida pela condição que oferece ao pesquisador de

aprofundar-se na compreensão dos fenômenos que estuda - ações dos indivíduos, grupos ou organizações em seu ambiente e contexto social interpretando-os segundo a perspectiva dos participantes da situação enfocada (TERENCE; ESCRIVÂO FILHO, 2006, p.2).

Carrega em si a possibilidade de uma visão mais ampla, na medida em que as situações e os indivíduos são vistos como um todo e estudados numa base histórica.

Este tipo de pesquisa considera que há uma relação dinâmica entre o mundo real e o sujeito, isto é, um vínculo indissociável entre o mundo objetivo em toda sua amplitude e complexidade e a subjetividade do sujeito que não pode ser traduzido em números (SILVA; MENEZES, 2005). O que valoriza o ambiente natural da pessoa e no qual diretamente se encontra (seu micro e mesossistema), levando em consideração como interpreta e como age frente aos fatores mais longevos (o exo e o macrossistema). Isso permite uma análise mais completa e um entendimento melhor dos fatores que podem conduzir ao desenvolvimento humano, já que

O entendimento do desenvolvimento humano exige mais do que a
observação direta do comportamento por parte de uma ou duas pessoas no
mesmo local; ele requer o exame de sistemas de interação de múltiplas
pessoas, não limitado a um único ambiente, e deve levar em conta aspectos
do meio ambiente além da situação imediata que contém o sujeito
(BRONFENBRENNER, 1996, p.18).

A exaltação da percepção da pessoa frente ao ambiente com que se relaciona é um fator decisivo, pois influi nas ações, nas atitudes, nas escolhas de cada pesquisado; revela deles valores, crenças e representações. Entendê-los é estar mais próximo da verdade.

Importa também que a pesquisa qualitativa transcende o corroborar ou não das hipóteses adotadas, ela permite um conhecimento novo e amplo, muitas vezes, inesperado ao pesquisador, pois, mais do que o manuseio das literaturas, busca o conhecimento oculto e ainda não vislumbrado que está nas pessoas que constroem o dia a dia escolar; tornando, assim, o investigador mais atento ao contexto. Isso significa que, ao contrário dos métodos quantitativos, os investigadores qualitativos 
dispõem das possibilidades quase infinitas de exploração que a riqueza dos detalhes pode proporcionar, obtendo muito mais do que apenas o conhecimento desejado.

Essa valorização da subjetividade da pessoa dentro da pesquisa oferece a ela um caráter fenomenológico ${ }^{10}$, e como tal

Preocupa-se com a descrição direta da experiência tal como ela é. A realidade é construída socialmente e entendida como o compreendido, o interpretado, o comunicado. Então, a realidade não é única: existem tantas quantas forem as suas interpretações e comunicações (SILVA; MENEZES, 2005, p.27)

A busca por essas parcelas de verdade que constroem a realidade, por essas visões que formam a complexidade do real estão diluídas nas etapas a seguir, auxiliando na coleta de dados (Inserção Ecológica, observação e textos) e na análise dos dados.

Sendo as pessoas, personificadas no professor, os elementos decisivos da pesquisa, é preciso, então, apresentar o local em que estão e quem são os participantes, assim como esclarecer a escolha de ambos.

\subsection{CAMPO DA PESQUISA}

A pesquisa foi realizada numa escola pública estadual, de um município do interior paulista. Definiu-se por essa instituição em razão da mesma abrigar o Ensino Médio e constituir-se num espaço de trabalho propício à realização de experiências interdisciplinares.

Tal escola, situada na periferia do município, é considerada de médio porte e atende a um contingente de alunos originários de uma comunidade de condição social econômica baixa.

Outro critério que pesou na definição pela escola em foco é a familiaridade do pesquisador com tal ambiente, constituindo o estudo do desenvolvimento no contexto (BRONFENBRENNER, 1996) e o fato de observar-se a não rotatividade da equipe docente desta escola, o que favorece a sólida convivência, formas concretas de interação e a convergência de ideias. 


\subsection{PARTICIPANTES}

Definiu-se por abordar enquanto participantes um grupo composto por quinze (15) professores efetivos, de ambos os sexos, que em tempos diferentes foram ingressando na unidade escolar e que atuam no Ensino Médio da escola já indicada.

A escolha pelo grupo de docentes deu-se pela própria relação de trabalho deles na instituição, bem como pelo conhecimento que eles têm do contexto no qual a escola se insere. "Conhecer o lugar de onde se fala é condição fundamental para quem necessita investigar como proceder ou desenvolver uma atitude interdisciplinar na prática cotidiana" (FAZENDA, 2002, p. 14).

Os participantes estão na escola desde o início dessa pesquisa e, com isso, podem conhecer os alunos e suas idiossincrasias, tanto quanto seus colegas de trabalho e suas atitudes. Também atendem a necessidade do tempo, pois a verificação de qualquer desenvolvimento deve ir além do mero acaso ou do circunstancial e se repetir no dia a dia e em vários lugares. Tal só poderia ser constatado pela permanência do professor na unidade escolar.

\subsection{INSTRUMENTOS E PROCEDIMENTOS DE COLETA DE DADOS}

Toda investigação das manifestações da atitude interdisciplinar e de sua relação com o desenvolvimento humano junto aos participantes da pesquisa e no ambiente escolhido tem como amparo a Inserção Ecológica (CECONELLO; KOLLER, 2003 - PRATI; COUTO; MOURA; POLETTO; KOLLER, 2008 - POLETTO; KOLLER, 2008). Esse instrumento técnico é mais do que uma escolha aleatória. Sua validade se encontra no auxílio em organizar os estudos daqueles que adotam uma pesquisa baseada na Teoria Bioecológica.

A teoria fundamentada por Bronfenbrenner $(1996,2011)$ exige um olhar múltiplo, buscando informações e entendimentos que estão além do ambiente direto no qual o pesquisador se encontra. A exigência, porém, não vem acompanhada de um plano definido. Para solucionar esse empecilho e avançar nessa teoria, é preciso 
somar outros instrumentos de maneira que eles obtenham todas as perspectivas necessárias para a adoção dos itens: processo, pessoa, contexto e tempo (PPCT).

É preciso superar os limites de um método único para que se tenha uma visão tão apurada do ser humano em desenvolvimento.

Os meio ambientes humanos e, ainda mais, as capacidades dos seres humanos de se adaptarem a, e reestruturarem, esses meio ambientes, são tão complexos e, sua organização básica que provavelmente não serão capturados através de modelos de pesquisa simplistas, unidimensionais, que não incluem a avaliação da estrutura e variação ecológica (BRONFENBRENNER, 1996, p.30).

Esse reforço técnico também é dado pela Inserção Ecológica. A junção de diferentes instrumentos amplia a apreensão de informações, permitindo uma análise e uma compreensão mais completa das atitudes e de suas ligações com o desenvolvimento. É nesse sentido que se supera a pesquisa tradicional.

A característica desse instrumento também valoriza a presença e a participação ativa do pesquisador, favorecendo a busca do desenvolvimento-nocontexto dentro do sistema de análise. Essa "inserção" favorece a utilização da observação como um dos complementos de investigação. Outro instrumento são os textos, escolhidos por apresentar informações que estão além das condições da simples observação. É o caráter "ecológico" da pesquisa indicando os pressupostos que transcendem ao microssistema. Justificam também a escolha pela observação e pelos textos os pormenores apontados a seguir.

Em primeiro lugar, a observação na escola pode gerar elementos esclarecedores dos fenômenos ocorridos, mesmo os que são familiares ao professor (VIANNA, 2003). Dentro da proposta deste trabalho, ela permite vislumbrar as atitudes interdisciplinares e suas ligações no processo de desenvolvimento, considerado quando as mudanças são manifestas regularmente e em longos períodos de tempo.

Acredita-se que tal procedimento permita determinar as causas necessárias do desenvolvimento, para a qual precisaríamos privar o organismo da circunstância hipotética (BRONFENBRENNER, 1996). Ao utilizar o próprio ambiente do sujeito como campo de pesquisa, permite-se maior veracidade em suas ações, uma espontaneidade em seu modo de ser mais elevado do que se conduzido a um lugar que lhe fosse estranho. 
A observação ajuda o pesquisador a identificar e a obter provas a respeito de objetivos sobre os quais os indivíduos não têm consciência, mas que orientam seu comportamento. Desempenha papel importante nos processos observacionais, no contexto da descoberta, e obriga o investigador a um contato mais direto com a realidade (LAKATOS; MARCONI, 1990, p.186).

Com ela, houve a oportunidade de perceber se a atitude interdisciplinar voltada à subjetividade dos sujeitos, à prática e à experiência, à necessidade de autoconhecimento, ao diálogo com o outro, a uma atitude que alcance uma dimensão humana para o saber ser (FAZENDA, 2009), presente no vocabulário dos professores, alcançava sua efetivação na atitude cotidiana e se ela se constituía realmente em valorização do outro, impulsionando o desenvolvimento.

A rigor, a observação dentro da Inserção Ecológica, segundo Ceconello e Koller (CECONELLO; KOLLER, 2003 - PRATI; COUTO; MOURA; POLETTO; KOLLER, 2008 - POLETTO; KOLLER, 2008), deve ser uma observação livre, assistemática, valorizando toda individualidade e espontaneidade das pessoas tanto na atitude quanto no sentir. Lembrando que trabalhar com pessoas é trabalhar com sentimentos, paradoxos, conflitos, ambiguidades e antagonismos, portanto, com a diversidade e com a multiplicidade dos aspectos dessa totalidade humana, produto de um saber local e universal (TAINO, 2008).

Porém, é impossível a qualquer pesquisador manter-se neutro ou imparcial, já que mesmo ele carrega suas crenças e concepções. Assim, por mais livre que fosse a observação, os princípios da interdisciplinaridade (coerência, humildade, respeito, desapego, espera vigiada) e os valores humanos (diálogo, reconhecimento, alteridade e reciprocidade) foram itens procurados durante o processo.

No mais, os participantes estiveram conscientes da observação e de que ela não constituiria qualquer ameaça ao grupo. Além disso, existiu a plena liberdade em refletir e em compartilhar o que desejarem com o pesquisador, tanto quanto questioná-lo sobre o que lhes for de interesse.

As informações obtidas pela observação ofereceram um vasto material de análise que são válidas por si só, porém, são insuficientes.

O entendimento do desenvolvimento humano exige mais do que a observação direta do comportamento por parte de uma ou duas pessoas no mesmo local; ele requer o exame de sistemas de interação de múltiplas pessoas, não limitado a um único ambiente, e deve levar em conta aspectos do meio ambiente além da situação imediata que contém o sujeito (BRONFENBRENNER, 1996, p. 13). 
Para completá-las, foi preciso avançar para sistemas mais distantes. É necessário conhecer características, ideias, conceitos que o sujeito carrega de outros ambientes. Para atingir essa concepção, adotou-se como instrumento o texto.

Em segundo lugar, enquanto a observação era feita, os participantes foram convidados a escrever sua compreensão sobre interdisciplinaridade. Sem a necessidade de qualquer pesquisa prévia, ofereceram o conceito que adquiriram até aquele momento. Mais do que ouvir ou reler teorias, eis o momento em que o professor expôs toda sua interpretação sobre o assunto. Hora em que sua voz foi realmente valorizada.

Como técnica de abordagem aos sujeitos, os textos compuseram relatos que permitiram abranger as dimensões pessoais, acadêmicas e profissionais dos participantes da pesquisa, servindo como instrumento de reconhecimento de si, do outro, das marcas e dos sentidos de sua trajetória, permitindo ao pesquisador apropriar-se dessas informações de modo que elas corroborem ou não a teoria construída (TAINO, 2008).

Os textos produzidos

visam a desenvolver e a pôr a prova novas formas de nomear e considerar, em termos pedagógicos, o que acontece nos mundos escolares e o que acontece aos atores educativos quando os fazem e neles transitam (SUAREZ, 2008, p.103).

O texto pretendia assumir uma função específica dentro da pesquisa ao reclamar sua própria validade e legitimidade ao construir conhecimento a partir da experiência de vida do docente.

O professor não era o simples repetidor de uma verdade já pronta, recebida das mais variadas e conflitantes literaturas. "Ele próprio abre uma perspectiva sobre a verdade, o exemplo de um caminho em direção ao verdadeiro que ele designa, pois a verdade é sobretudo o caminho da verdade" (GUSDORF, 1987, p.57). Assim, as respostas que realmente valem e nos transformam não estão encerradas nos livros; elas pertencem ao dia a dia, e é ao vivenciá-las que descobrimos todo conhecimento desejado.

Toda teoria externa, tão importante para a formação e para a continuidade dela, não está completa. Muitas dessas teorias sucumbem às distintas questões impostas pelo cotidiano particular de cada escola, professor ou aluno. 
Cabe ao professor transformar a "lei geral" em algo particular, que atenda as necessidades daquela realidade. Ao fazer isso, é o novo que emerge, é algo inédito, já distinto do que originalmente fora feito.

Essa transformação e ampliação do conhecimento era intenção do texto. Esse material obtido logo no início da pesquisa ofereceu o conhecimento atual que os docentes têm a respeito da interdisciplinaridade e, principalmente, da atitude interdisciplinar.

Com esse instrumento, o docente pôde mostrar, tal como indica Bronfenbrenner (1996, 2011), o modo como percebe os ambientes que o influenciam. Pelo texto, foi possível analisar a interpretação que o docente faz das leis que orientam a escola (cuja inserção da atitude interdisciplinar é solicitada), indicando sua visão sobre o macrossistema. Também pôde opinar sobre a importância das relações dentro do processo de aprendizado (microssistema) e mais ainda do processo de desenvolvimento.

Tudo isso se somou aos dados obtidos na observação dando uma visão global do professor interdisciplinar em desenvolvimento.

\subsection{PROCEDIMENTO DE ANÁLISE DOS DADOS}

A investigação da atitude interdisciplinar na prática docente conduziu a procura das manifestações tal como elas ocorreram e como foram percebidas no dia a dia. Com o uso da Inserção Ecológica, amplificada pela observação e pelos textos, apreenderam-se as atitudes do modo como foram vividas, rompendo com qualquer teoria alienada da realidade.

A obtenção desses dados se associou muito à investigação fenomenológica, no sentido de "ir à coisa mesma", descrevendo-a e analisando-a tal como aparecia. Havia a consciência de que o impulso da investigação

deve partir das próprias coisas. Para Husserl, não sou eu, nem as minhas convicções, e, sim, as próprias coisas, como estas se revelam na sua pureza irrefutável, que têm de se impor como testemunho da verdade. Não é das filosofias que deve partir o impulso de investigação, mas, sim, das coisas e dos problemas (BUENO, 2003, p.11). 
A própria forma de construir conhecimento, amparada pela visão fenomenológica da interdisciplinaridade, superestimando a visão subjetiva do docente em suas angústias e inquietações, salientou essa íntima ligação

O reconhecimento desse vínculo com a fenomenologia fez dela a forma de analisar os dados. O material obtido pela descrição do pesquisador (a observação) ou pelos participantes (os textos) foi organizado e, a partir deles, eram elaboradas as interpretações que se articulavam com o objetivo, com os teóricos que sustentaram a pesquisa e com a reflexão do investigador.

A articulação entre os dados iniciou-se com a organização dos textos em um quadro sistematizado de modo a tornar claras a visão de cada participante, as invariantes e a análise do pesquisador. Com isso, pretendeu-se acompanhar o ensinamento que diz:

Como modo de pesquisar o que existe, Edmund Husserl refere-se à descrição exaustiva do fenômeno e aos invariantes detectados nas diferentes descrições, de modo que a reflexão sobre tais invariantes, baseada na inteligibilidade do que permitem compreender, nos conduzisse à essência do fenômeno investigado. E a essência desvela isto que existe pelo modo como existe (BICUDO, 2000, p.73, grifo do autor).

Após o quadro analítico, os textos foram confrontados com a literatura construída. Uniu-se a esse diálogo, ajudando a ligar, discutir e refletir sobre os escritos o conteúdo da observação ecológica.

Há um vasto material obtido pela observação. Por ser ela livre e assistemática, tudo o que se mostrava diferente ou ligado a essa pesquisa ficou registrado. Cabendo ao pesquisador, após leituras e releituras do material, identificar o que fosse relevante para a construção do conhecimento em questão, ou seja, na análise dos dados, quem definiu o que era importante foi a pessoa ativa da pesquisa, que em alguns momentos foi a pessoa do docente a ser pesquisado, expressando seus interesses e visões por meio dos textos, em outras - e decisivas - foi o pesquisador, com sua observação, seleção e análise das informações.

Ao ser colocado lado a lado o material coletado e suas interpretações, solicitou-se uma interpretação hermenêutica, aos moldes de Ricoeur, para quem

toda linguagem, ao dizer, interpreta. Ela é, ao mesmo tempo, interpretação de uma realidade e uma interpretação, que pode ser auto-interpretação, daquele que fala da realidade (BICUDO, 2000, p.79). 
Assim, existiu sempre a tentativa de obter o sentido oculto em cada ideia, os pressupostos para cada atitude. Houve o anseio em comparar as atitudes às palavras e à teoria, de modo a buscar entender toda a complexidade que constitui o agir docente e verificar se nesse emaranhado de conhecimento há manifestações da atitude interdisciplinar e se ela auxilia no desenvolvimento humano. 


\section{RESULTADOS E DISCUSSÃO}

A pesquisa de campo iniciou-se na reunião de planejamento escolar, que uniu os professores de modo que esses pudessem trocar ideias, discutir e apropriar-se de novos conceitos; também era possível inteirar-se das mudanças impostas pela secretaria da educação, alterações que diziam respeito à jornada, aos dias de licença e aos procedimentos de faltas. Era o momento em que os professores da escola se reuniram em sua maioria, confirmando-se como momento ideal para que a proposta da pesquisa e a solicitação da participação de alguns fossem feitas.

Durante os intervalos, houve a conversa e o pedido direto ao professor, de modo que ele se sentisse livre para aceitar ou recusar o convite feito. Aqueles docentes a quem o pesquisador não teve oportunidade de convidar no dia do planejamento foram indagados nos dias que se seguiram. Após todo esclarecimento sobre os motivos e os procedimentos da pesquisa, tendo o aceite dos docentes e a adesão registrada por meio do Termo de Consentimento Livre e Esclarecido, a observação teve seu início. Entretanto, o primeiro material a que o pesquisador obteve acesso foram os textos.

Quando solicitados que escrevessem abertamente sua compreensão sobre interdisciplinaridade, todos manifestaram disposição em ajudar. Elogiaram a decisão, incentivaram o quanto puderam e todos, sem exceção, comprometeram-se a entregar 0 texto. Dos quinze professores participantes, doze cumpriram sua promessa. Apesar dos insistentes pedidos e das constantes recordações quanto ao combinado, ainda assim, a totalidade do material não foi alcançada.

Mesmo sem participarem diretamente da etapa referente aos textos, os professores, continuam a fazer parte da pesquisa. Suas ações serão analisadas tal como as outras, e a não entrega dos textos torna-se um item a ser analisado junto às demais atitudes observadas. Por esse motivo, ao organizar em quadros o material coletado, houve espaço para os três (3) professores.

Os fragmentos do material apresentado, transcrito tal como os professores o ofereceram, derivam da análise prévia do pesquisador, separando elementos considerados significativos (unidades de significado) conforme instruções de tratamento de dados de Bicudo (2000). Após esse trabalho propedêutico, o diálogo do pesquisador com os textos e com os teóricos tornou-se possível. 
Quadro 1 - Análise do discurso escrito e unidades de significado

\begin{tabular}{|c|c|}
\hline Discurso PROFESSOR A & Redução em unidades de significado \\
\hline $\begin{array}{l}\text { Acho que é a interação entre as disciplinas ou } \\
\text { áreas do saber. É a produção do conhecimento de } \\
\text { uma maneira inteira e não fragmentada. Um tema } \\
\text { pode ser trabalhado por várias disciplinas onde } \\
\text { cada um irá explorar o máximo dentro de sua área. } \\
\text { É um trabalho de parceria das disciplinas com um } \\
\text { único objetivo: a busca do conhecimento. }\end{array}$ & $\begin{array}{l}\text { 1. Interação entre as disciplinas. } \\
\text { 2. Produção de conhecimento não } \\
\text { fragmentado. } \\
\text { 3. Tema trabalhado por várias disciplinas. } \\
\text { 4. Exploração de um tema no máximo por } \\
\text { disciplina. }\end{array}$ \\
\hline Discurso PROFESSOR B & Redução em unidades de significado \\
\hline $\begin{array}{l}\text { A interdisciplinaridade é uma questão de abertura, } \\
\text { não preconceituosa, onde todo conhecimento é } \\
\text { igualmente importante, pois, o conhecimento } \\
\text { pessoal anula-se frente ao saber universal } \\
\text { (interação entre as disciplinas). }\end{array}$ & $\begin{array}{l}\text { 1. Abertura não preconceituosa ao } \\
\text { conhecimento. } \\
\text { 2. Anulação do conhecimento pessoal } \\
\text { frente ao saber universal. }\end{array}$ \\
\hline Discurso PROFESSOR C & Redução em unidades de significado \\
\hline $\begin{array}{l}\text { A interdisciplinaridade aplicada na metodologia } \\
\text { escolar é muito positiva, pois aproxima o aluno da } \\
\text { realidade. As matérias interagem e acrescentam } \\
\text { informações importantes para a boa formação } \\
\text { escolar. } \\
\text { O fato de não estudar as matérias isoladamente, } \\
\text { desperta no aluno um interesse maior pelo } \\
\text { aprendizado. }\end{array}$ & $\begin{array}{l}\text { 1. Aproximação do aluno à realidade por } \\
\text { meio da interdisciplinaridade. } \\
\text { 2. Interação entre as matérias. } \\
\text { 3. Ligação das matérias, despertando } \\
\text { maior interesse nos alunos. }\end{array}$ \\
\hline Discurso PROFESSOR D & Redução em unidades de significado \\
\hline $\begin{array}{l}\text { Sou a favor da interdisciplinaridade, ela mostra que } \\
\text { é uma maneira eficaz para os bons resultados, } \\
\text { mas também é mais trabalhosa e ainda é este o } \\
\text { ponto de resistência de muitos colegas que } \\
\text { preferem trabalhar quase incógnitos, de maneira } \\
\text { mais simples para atingir seus objetivos. }\end{array}$ & $\begin{array}{l}\text { 1. Maneira eficaz para bons resultados. } \\
\text { 2. Trabalhosa, a ponto de gerar } \\
\text { resistência. } \\
\text { 3. Preferência de alguns docentes pelo } \\
\text { trabalho incógnito. }\end{array}$ \\
\hline Discurso PROFESSOR E & Redução em unidades de significado \\
\hline $\begin{array}{l}\text { A interdisciplinaridade vem a ser a comunicação } \\
\text { entre as diversas disciplinas escolares. Podendo } \\
\text { haver vários estágios de comunicação. } \\
\text { Essa comunicação se manifesta quando as } \\
\text { disciplinas trabalham conjuntamente, organizando } \\
\text { e sincronizando seus currículos, com o objetivo de } \\
\text { explicar melhor a realidade e levar o aluno a um } \\
\text { conhecimento mais pleno sobre determinado fato } \\
\text { ou assunto. } \\
\text { Tal articulação das disciplinas se mostra bastante } \\
\text { positiva na medida em que permite, torna possível } \\
\text { ao aluno, fazer ligações e correspondências entre } \\
\text { as diversas disciplinas escolares. Tornando o } \\
\text { conhecimento mais articulado, é mais fácil para o } \\
\text { aluno perceber os assuntos estudados presentes } \\
\text { em sua realidade, em seu cotidiano, possibilitando } \\
\text { assim um melhor aprendizado. }\end{array}$ & $\begin{array}{l}\text { 1. Comunicação entre as disciplinas. } \\
\text { 2. Estágios variados de comunicação. } \\
\text { 3. Comunicação se manifesta quando as } \\
\text { disciplinas trabalham conjuntamente, } \\
\text { organizando e sincronizando seus } \\
\text { currículos. } \\
\text { 4. Comunicação que explica melhor a } \\
\text { realidade. } \\
\text { 5. Ligações e correspondências entre as } \\
\text { diversas disciplinas escolares pelos } \\
\text { alunos. } \\
\text { 6onhecimento torna-se mais } \\
\text { articulado. } \\
\text { 7. Possibilidade de o aluno perceber os } \\
\text { assuntos em sua realidade. }\end{array}$ \\
\hline
\end{tabular}




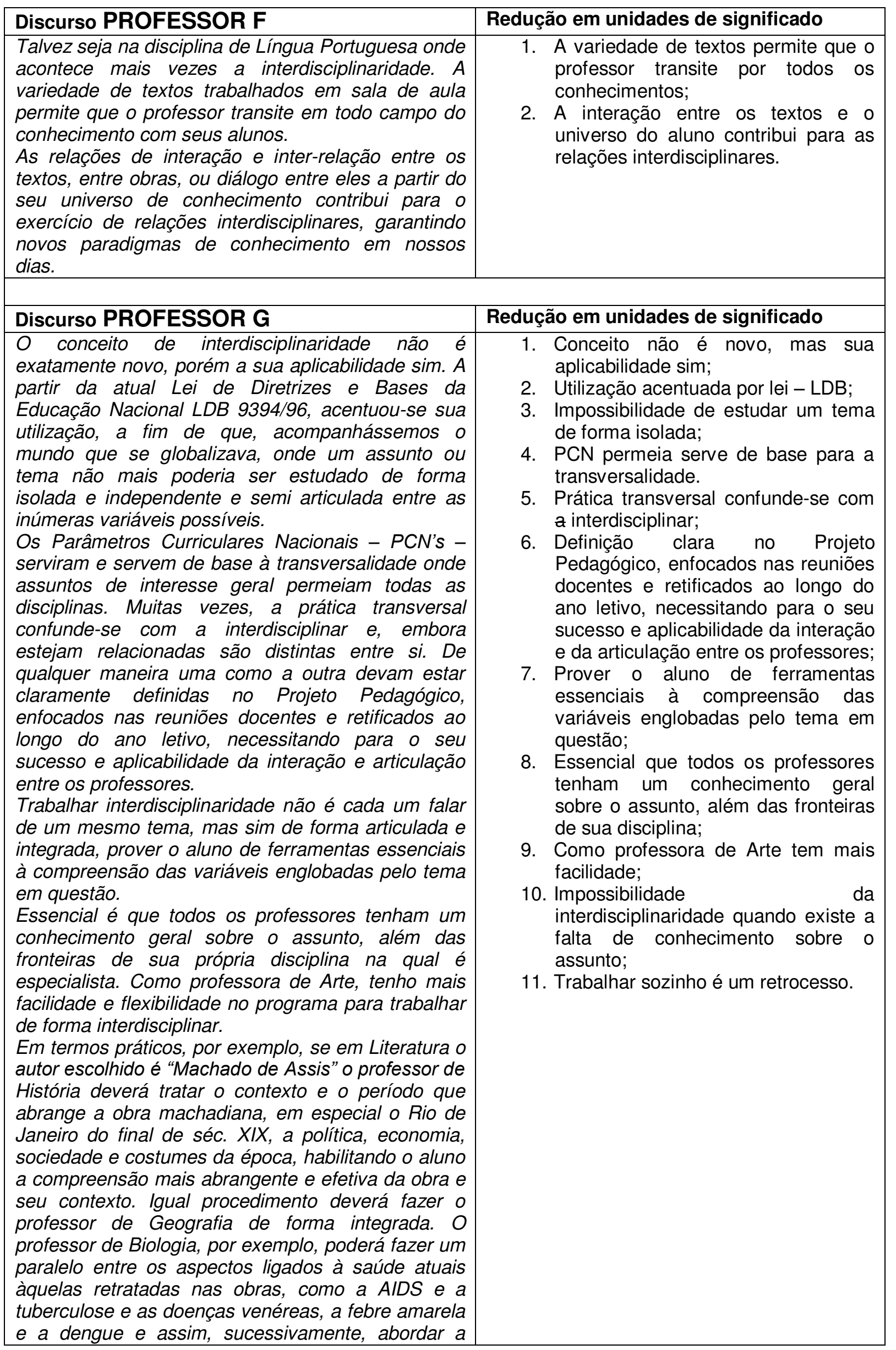




\begin{abstract}
questão ambiental e urbana do Brasil e outros aspectos. E assim serão múltiplas as formas pelas quais cada disciplina fornecerá ao aluno mecanismos para uma imersão no mundo da literatura, sem falar na área da Arte que pode abordar a música, a dança, a arte cênica, a pintura, a poesia, escultura, etc. Todavia, não será possível se todos não tiverem essa consciência e conhecimento dos aspectos ligados direta $e$ indiretamente ao tema em pauta.

Não podemos esquecer que trabalhar sozinho nos dias de hoje é um retrocesso, a ideia é um ensino cada vez mais globalizado pois o aluno já é avaliado pelo global.
\end{abstract}

\title{
Discurso PROFESSOR H \\ A interdisciplinaridade é possível e com um alto resultado devido: \\ 1- Material didático muito bem selecionado; \\ 2- Número de alunos por sala; \\ 3- Preparação dos docentes; \\ 4- Disponibilidade do grupo gestor.
}

Redução em unidades de significado

1- Material apropriado;

2- Número excessivo de alunos por sala precisa ser evitado;

3- Preparação dos docentes;

4- Disponibilidade dos gestores.

\section{Discurso PROFESSOR I}

Inter = quer dizer ligação.

Há ligação de uma área do conhecimento com a outra.

Por exemplo, o meio ambiente (que é um projeto de trabalho interdisciplinar) pode também ser trabalhado em português.

É necessário que haja uma integração entre as disciplinas.

\section{Discurso PROFESSOR J}

Atualmente, a interdisciplinaridade é uma "área" muito comentada e discutida na educação. $O$ trabalho interdisciplinar é recente no país e por isso há dificuldades de definir as diretrizes e eixo de trabalho. O ramo acadêmico se dedica a refletir e tentar buscar acordos e formas de trabalhar a interdisciplinaridade. De acordo com o que eu estudei e pesquisei as disciplinas/assuntos devem ser trabalhados em conjunto. O tema interdisciplinar escolhido deve ser trabalhado a partir de diferentes olhares orientado pelo profissional do assunto. Esta é a dificuldade encontrada quando se dedica ao trabalho interdisciplinar.

Tomando como exemplo um impacto ambiental, o profissional da área de ciências/meio ambiente deve orientar os problemas e as causas a partir dos aspectos bióticos e abióticos. Decorrente dos efeitos físico-biológicos, o profissional de humanas pode orientar os problemas sociais, econômicos e políticos e assim sucessivamente. A causa ambiental é estritamente relaciona à política e esse olhar interdisciplinar que deve ser transmitido para os alunos. Muitas vezes, os profissionais tendem a selecionar os assuntos que lhe cabem e tratá-los separadamente. Assim, continua-se o tratamento
Redução em unidades de significado

1- Ligação entre as áreas;

2- Mesmo tema pode ser trabalhado por várias disciplinas;

3- Integração entre as disciplinas.

Redução em unidades de significado

1. Uma área muito comentada e discutida na educação;

2. O trabalho interdisciplinar é recente no país;

3. O ramo acadêmico se dedica a refletir e tentar buscar acordos e formas de trabalhar a interdisciplinaridade;

4. As disciplinas devem trabalhar em conjunto

5. O tema deve ser trabalhado a partir de diferentes olhares;

6. Os assuntos devem ser discutidos ao mesmo tempo;

7. O professor-participante cursa pósgraduação (ciência ambiental); 


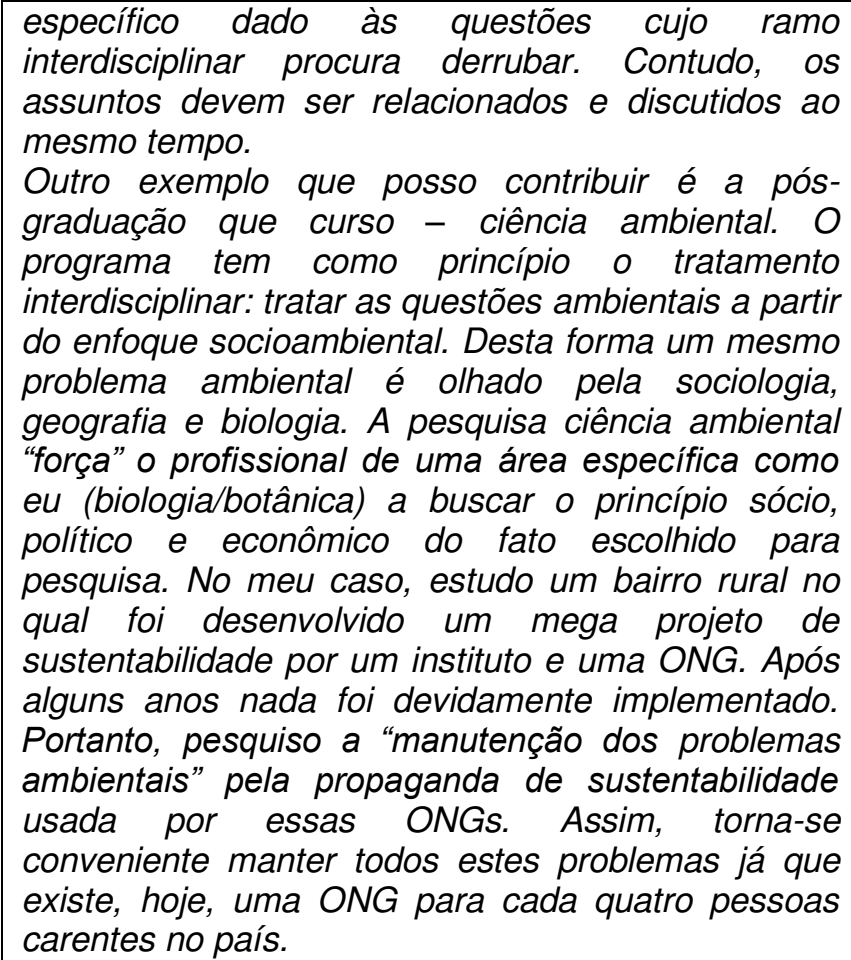

\section{Discurso PROFESSOR K}

É uma palavra complicada na escrita, mas é de suma importância a tentativa de se buscar um novo caminho contra o conformismo mental, não criativo, contra 0 inevitável comodismo das mentes educacionais ou futuristas.

A interatividade das coisas, das situações, das ações, está se perdendo na busca da segmentação das ideias no nosso mundo globalizado.

\section{Discurso PROFESSOR L}

Esses são os principais itens para que haja interdisciplinaridade: disposição, empenho, colaboração, persistência, etc; de todo corpo docente na preparação ou lapidação dos alunos... Experiência própria: Na escola particular que leciono desde 1994 sempre trabalhamos visando o desenvolvimento de nossos alunos desde o Maternal até o $9^{\circ}$ ano ( $8^{a}$ série). A partir do ano 2000 adotou-se uma apostila (Positivo) que ao longo desses 10 anos passou a trabalhar de forma diferenciada e aprimorada, isto porque, hoje temos todas as disciplinas interligadas. $O$ que nos proporcionou mais liberdade, mais disposição, pois as disciplinas não são estanques, em todas as fases de ensino.

Temos cursos com certificação do pessoal especializado do Positivo uma ou duas vezes ao ano. Temos acesso ao Portal Positivo, onde tiramos dúvidas diretamente com o coordenador da área.
Redução em unidades de significado

1- Palavra complicada na teoria;

2- Caminho contra o conformismo e comodismo mental;

3- A interatividade está se perdendo;

4- Segmentação das ideias.

Redução em unidades de significado

1- Para haver interdisciplinaridade, é preciso disposição, empenho, colaboração, persistência do professor;

2- Trabalho em conjunto em todas as séries;

3- Material auxilia na interligação das disciplinas;

4- Cursos de especialização;

5- Amparo conceitual (pela internet). 


\begin{tabular}{|l|l|}
\hline Discurso PROFESSOR M & Redução em unidades de significado \\
\hline Não entregou o texto solicitado & \\
\hline \multicolumn{2}{|c|}{} \\
\hline Discurso PROFESSOR N & Redução em unidades de significado \\
\hline Não entregou o texto solicitado & \\
\hline \multicolumn{2}{|c|}{} \\
\hline Discurso PROFESSOR O & Redução em unidades de significado \\
\hline Não entregou o texto solicitado & \\
\hline
\end{tabular}

FONTE: DADOS DA PESQUISA

Com o material organizado, alguns elementos tornaram-se evidentes. A primeira grande pergunta consistia em saber o que os professores conheciam sobre interdisciplinaridade. O que em si não é tarefa fácil, ao contrário, é hoje uma tarefa ingrata e difícil, por ser "uma palavra complicada na escrita" (PROFESSOR K), devido à sua característica polissêmica, o que "Ihe oferece o risco de não ter qualquer significado" (LENOIR, 2005-2006, p.3).

As respostas variaram de acordo com a compreensão de cada um, eram mais ou menos elaboradas a partir das experiências individuais; a justificativa e o entendimento também se alteraram de acordo com a continuidade ou não dos estudos.

O mais importante de tudo o que foi lido é que o resultado em questão aponta que há, no mínimo, uma compreensão convergente a respeito da interdisciplinaridade, principalmente se comparado ao que solicita e explica o Conselho Nacional de Educação:

A interdisciplinaridade deve ir além da mera justaposição de disciplinas e,
ao mesmo tempo, evitar a diluição delas em generalidades. De fato, será
principalmente na possibilidade de relacionar as disciplinas em atividades
ou projetos de estudo, pesquisa e ação, que a interdisciplinaridade poderá
ser uma prática pedagógica e didática adequada aos objetivos do ensino
médio (CNE 15, 2008, p.38).

Como essa interpretação aparece frequentemente nas formações e reuniões de professores, nada mais comum do que a assimilação dessa compreensão. Isso explica respostas como:

Acho que é a interação entre as disciplinas ou áreas do saber. É a produção do conhecimento de uma maneira inteira e não fragmentada. Um tema pode ser trabalhado por várias disciplinas onde cada um irá explorar o máximo dentro de sua área. É um trabalho de parceria das disciplinas com um único objetivo: a busca do conhecimento (PROFESSOR A). 
A resposta acima apenas resume o entendimento da maioria. Dentro de várias respostas, existe um núcleo comum em relação à ideia de interdisciplinaridade enquanto "interação", "não fragmentação" entre as disciplinas. O que pareceu estar claro nas seguintes respostas:

As matérias interagem e acrescentam informações importantes para a boa formação escolar (PROFESSOR C);

A interdisciplinaridade vem a ser a comunicação entre as diversas disciplinas escolares (PROFESSOR E);

Um assunto ou tema não mais poderia ser estudado de forma isolada e independente e semi articulada entre as inúmeras variáveis possíveis (PROFESSOR G);

Inter = quer dizer ligação.

Há ligação de uma área do conhecimento com a outra (PROFESSOR I);

De acordo com o que eu estudei e pesquisei as disciplinas/assuntos devem ser trabalhados em conjunto (PROFESSOR J).

Se levarmos em consideração a ideia de que a memória tem um aspecto seletivo, armazenando informações, conceitos, momentos, imagens, pessoas que Ihes são úteis ou importantes, sobretudo as que Ihes são importantes, pode-se entender e exaltar que a interdisciplinaridade tem, junto aos docentes, um significado positivo.

Como fora apresentado no capítulo sobre a instituição escolar, a interdisciplinaridade na escola também é uma solicitação externa. O macrossistema, ou seja, as leis atuais que conduzem o dia a dia escolar, indica quase uníssono sua adoção. É o que consta, por exemplo, no Parecer CNE 11/2009 quando pede para "Organizar os tempos e os espaços com ações efetivas de interdisciplinaridade e contextualização do conhecimento" (p.4).

Essa força coercitiva tão longínqua, porém, não pode receber o crédito maior pela presença da ideia de interdisciplinaridade na escola. Outras teorias antes dela já serviram como base para o trabalho docente, mas não obtiveram a mesma aceitação. Tantos conceitos se perderam como se perde um sonho ao despertar, incapazes que são de confrontar a realidade. A verdade é que "a interdisciplinaridade não é decretada, ela se constrói” (RAYNAUT, 2011, p.102) e sua presença na escola é opção principalmente do próprio professor. 
Há a avaliação positiva para esse novo modo de construir conhecimento, tal como "Sou a favor da interdisciplinaridade, ela mostra que é uma maneira eficaz para os bons resultados" (PROFESSOR D) ou "É uma palavra complicada na escrita, mas é de suma importância" (PROFESSOR K). Não se pode dizer que são respostas ingênuas, já que essa aprovação vem lado a lado com a consciência do momento em que se vive. Afinal, não se pode negar a semelhança de visão entre Olga Pombo, ao afirmar que:

Assiste-se, no século XX, a uma situação disciplinar sem precedentes que, tendo por base o acelerado progresso científico que se desencadeou no século passado e a ruptura que então se estabeleceu entre ciência e filosofia, se caracteriza por uma crescente fragmentação e especialização do conhecimento (1993, p.173).

E o PROFESSOR K, que diz:

A interatividade das coisas, das situações, das ações, está se perdendo na busca da segmentação das ideias no nosso mundo globalizado.

Existe também a noção do desafio que está por vir, quando se entende que a proposta interdisciplinar se impõe ao

propor a tarefa precípua de operar nas fronteiras disciplinares e na
(re)ligação de saberes, tendo como finalidade última dar conta de
fenômenos complexos, de diferentes naturezas. A interdisciplinaridade
busca responder, assim, a problemas gerados pelo próprio avanço da
ciência moderna disciplinar, quando esta se caracteriza como
fragmentadora e simplificadora do real (ALVARENGA; PHILIPPI JR;
SOMMERMAN; ALVAREZ; FERNANDES, 2011, p.21).

Em outras palavras, a interdisciplinaridade é necessária ao favorecer "a produção do conhecimento de uma maneira inteira e não fragmentada" (PROFESSOR A), o que permitiu que "acompanhássemos o mundo que se globalizava, onde um assunto ou tema não mais poderia ser estudado de forma isolada e independente e semi-articulada entre as inúmeras variáveis possíveis" (PROFESSOR G).

Da mesma forma com que se verificam entendimentos e compreensões, há também alguns pontos que geraram discussões e discordâncias. São confusões ideológicas que, se não forem esclarecidas, podem dificultar a vivência da interdisciplinaridade. É o caso da diferença entre disciplina, multidisciplinaridade, interdisciplinaridade e transdisciplinaridade. Em alguns momentos, esses conceitos 
parecem mesclar-se ao ponto de se tornarem um amálgama de ideias que representa tudo, menos interdisciplinaridade.

O primeiro sintoma dessa confusão está na ideia de abandonar a disciplina de origem, quando "o conhecimento pessoal anula-se frente ao saber universal" (PROFESSOR B). Não há essa anulação do conhecimento pessoal, nem tão pouco do conhecimento disciplinar. Até mesmo porque nosso modo de ingressar na interdisciplinaridade é por meio do conhecimento que já temos e esse é ainda um conhecimento especializado.

\begin{abstract}
Especialização que tem produzido resultados notáveis, magníficos. Não podemos recusar, nem menosprezar, nem esquecer, que foi esse procedimento analítico da ciência moderna que deu origem a todos os conhecimentos e a todo o bem-estar que the devemos (POMBO, 2005, p.6)
\end{abstract}

A compreensão da realidade, por mais que exija um pensamento mais completo, não pode desprezar o particular. Esses servem como ponto de origem para a construção de todo saber, principalmente porque é impossível à pessoa tudo saber e ela precisa do conhecimento alheio para juntos costurarem a imagem do real. Essa troca é recíproca, pois cada pessoa busca no outro o que lhe falta, mas também precisa oferecer algo. Esse algo é seu conhecimento disciplinar.

Quando essas pessoas se põem a dialogar, elas completam o método cartesiano. Elas dividiram os problemas em partes menores - as disciplinas - mas retornam ao todo ao partilhar e confrontar seus resultados. Contudo, o acompanhante do diálogo é o conflito. Visões diferentes trarão inúmeros esclarecimentos, tanto quanto oferecerão novas dúvidas. Nesse momento, cada um há de retornar ao seu ambiente disciplinar, buscar novas visões, enriquecer seu conhecimento, para, novamente, disponibilizá-lo aos outros.

Quando a interdisciplinaridade nega as ciências particulares, ela corre o risco de produzir conhecimentos superficiais. Arrisca-se a falar do todo sem sequer dizer nada. Por isso, as disciplinas continuam a fazer parte ímpar na construção do conhecimento.

Além da preocupação em fazer permanecer o valor das disciplinas, a dificuldade aumenta quando se procura entender o modo como se procede a relação entre os saberes. Sabe-se que na interdisciplinaridade, mais do que discutir temas sobre óticas diferentes, é preciso que essas visões se articulem e produzam um único saber, mais completo. 
Assim, quando se lê "Um tema pode ser trabalhado por várias disciplinas onde cada um irá explorar o máximo dentro de sua área" (PROFESSOR A) ou ainda "O tema interdisciplinar escolhido deve ser trabalhado a partir de diferentes olhares orientado pelo profissional do assunto" (PROFESSOR J), pode-se entender a confusão existente.

A resposta a esse problema inicia-se com a escrita do PROFESSOR E ao apontar que pode "haver vários estágios de comunicação", mas um real esboço de explicação só será lido em outro texto

Muitas vezes, a prática transversal confunde-se com a interdisciplinar e, embora estejam relacionadas são distintas entre si...

Trabalhar interdisciplinaridade não é cada um falar de um mesmo tema, mas sim de forma articulada e integrada, prover o aluno de ferramentas essenciais à compreensão das variáveis englobadas pelo tema em questão (PROFESSOR G).

Aqui se apresenta a consciência da superação de um simples paralelo de opiniões tal como prega a multidisciplinaridade. É esse conhecimento que permite ao mesmo professor exemplificar sua visão.

\begin{abstract}
Em termos práticos, por exemplo, se em Literatura o autor escolhido é "Machado de Assis" o professor de História deverá tratar o contexto e o período que abrange a obra machadiana, em especial o Rio de Janeiro do final de séc. XIX, a política, economia, sociedade e costumes da época, habilitando o aluno a compreensão mais abrangente e efetiva da obra e seu contexto. Igual procedimento deverá fazer o professor de Geografia de forma integrada. O professor de Biologia, por exemplo, poderá fazer um paralelo entre os aspectos ligados à saúde atuais àquelas retratadas nas obras, como a AIDS e a tuberculose e as doenças venéreas, a febre amarela e a dengue e assim, sucessivamente, abordar a questão ambiental e urbana do Brasil e outros aspectos. E assim serão múltiplas as formas pelas quais cada disciplina fornecerá ao aluno mecanismos para uma imersão no mundo da literatura, sem falar na área da Arte que pode abordar a música, a dança, a arte cênica, a pintura, a poesia, escultura, etc. Todavia, não será possível se todos não tiverem essa consciência e conhecimento dos aspectos ligados direta e indiretamente ao tema em pauta (PROFESSOR G).
\end{abstract}

Outros docentes o acompanham na tentativa de ilustrar essa relação entre os saberes - é o caso do PROFESSOR F:

Talvez seja na disciplina de Língua Portuguesa onde acontece mais vezes a interdisciplinaridade. A variedade de textos trabalhados em sala de aula permite que o professor transite em todo campo do conhecimento com seus alunos.

As relações de interação e inter-relação entre os textos, entre obras, ou diálogo entre eles a partir do seu universo de conhecimento contribui para o exercício de relações interdisciplinares, garantindo novos paradigmas de conhecimento em nossos dias (PROFESSOR F). 


\title{
E do PROFESSOR J:
}

\begin{abstract}
Tomando como exemplo um impacto ambiental, o profissional da área de ciências/meio ambiente deve orientar os problemas e as causas a partir dos aspectos bióticos e abióticos. Decorrente dos efeitos físico-biológicos, o profissional de humanas pode orientar os problemas sociais, econômicos e políticos e assim sucessivamente. A causa ambiental é estritamente relaciona à política e esse olhar interdisciplinar que deve ser transmitido para os alunos. Muitas vezes, os profissionais tendem a selecionar os assuntos que lhe cabem e tratá-los separadamente. Assim, continua-se $o$ tratamento específico dado às questões cujo ramo interdisciplinar procura derrubar. Contudo, os assuntos devem ser relacionados e discutidos ao mesmo tempo.
\end{abstract}

Os exemplos citados, assim como as respostas mais detalhadas, pertencem a dois professores que têm o estudo por característica. Um deles, interessado pela possibilidade de atuar na direção (por vezes é convidado para ser vice-diretor), necessita lidar com todo o conjunto de leis que regem a escola. Isso transparece em seu texto ao apontar a LDB e os PCN's ${ }^{11}$. O outro estava nos últimos meses de mestrado, cujo curso já tem um formato interdisciplinar. Ao que aponta o material coletado, a continuidade nos estudos os fez mais aptos a explicar suas perspectivas.

Há outros dois aspectos que parecem relevantes a esse pesquisador. Um deles diz respeito aos benefícios da interdisciplinaridade. Os benefícios dessa nova forma de conhecimento estão, muitas vezes, direcionados aos alunos:

O fato de não estudar as matérias isoladamente, desperta no aluno um interesse maior pelo aprendizado (PROFESSOR C).

Tornando o conhecimento mais articulado, é mais fácil para o aluno perceber os assuntos estudados presentes em sua realidade, em seu cotidiano, possibilitando assim um melhor aprendizado (PROFESSOR E).

Pouco se discute sobre a importância da interdisciplinaridade para o próprio professor, da possibilidade dele em fazer parte de um diálogo que o una aos teóricos que estuda, de modo a tornar-se uma pessoa que transcenda à simples repetição de ideias. Talvez assim seja porque "é mais trabalhosa e ainda é este o ponto de resistência de muitos colegas que preferem trabalhar quase incógnitos, de maneira mais simples para atingir seus objetivos" (PROFESSOR D).

Direcionar a interdisciplinaridade para dentro da atuação docente é retirar o professor de sua zona de conforto, fazendo-o assumir o desafio de constantemente se aprimorar. Mais até, a interdisciplinaridade refaz o professor enquanto pesquisador, levando-o a se apoiar nas teorias já prontas, mas, principalmente, 
ajuda a usar sua experiência e os aprendizados conquistados ao longo de sua carreira para questionar o dogmaticamente oferecido e, então, construir também ele suas teorias.

Das dúvidas construídas e trabalhadas surge um desafio - o desafio de criar teoria, uma teoria nascida de uma prática intensamente vivida. Esse desafio vai se explicitando na superação de múltiplos obstáculos (FAZENDA, 2005, p.8).

Das dúvidas, dos questionamentos, verdades são construídas. Do mesmo material com que nascem suas angústias e suas dificuldades, bem como suas certezas e conquistas, o professor constrói suas respostas que geralmente significam muito mais do que qualquer outra pseudo-solução encontrada nos livros. Elas atendem com maior propriedade as necessidades emergentes, pois têm a mesma origem: o dia a dia.

A elaboração de respostas, de saberes pelo docente o faz apresentar sua identidade; é sua vida transformada em teoria. "A trilha interdisciplinar caminha do ator ao autor de uma história vivida, de uma ação conscientemente exercida a uma elaboração teórica arduamente construída" (FAZENDA, 2002, p.15). Fazê-lo não é fácil, já que, além de contar sua história, o docente pesquisador deve dar a ela clareza e rigor, permitindo a transposição do caráter pessoal para o social.

Apesar de árduo, quando o professor aceita tal desafio imposto pela interdisciplinaridade, ele se transforma qualitativamente. O conhecimento que então tem a partilhar não é mais um puro conhecimento teórico, é um saber vivido, por isso, capaz de contagiar aos que estão com ele, professores ou alunos.

Mesmo com os benefícios apontados, é preciso reconhecer que "o conceito de interdisciplinaridade não é exatamente novo, porém a sua aplicabilidade sim" (PROFESSOR G), talvez porque que "o ramo acadêmico se dedica a refletir e tentar buscar acordos e formas de trabalhar a interdisciplinaridade" (PROFESSOR J), mas, aos fazê-lo, perde-se em teorias. É preciso então, antes de tudo, vivenciar essa interdisciplinaridade, torná-la efetivamente uma ATITUDE INTERDISCIPLINAR para que a ação guie toda escrita.

Por mais diferentes que fossem os participantes, a interdisciplinaridade descrita por eles não alcançou a questão da atitude interdisciplinar, amparada pelos princípios da humildade, coerência, espera, respeito e desapego (FAZENDA, 2002, p.11). Contudo, na ausência da descrição, há sempre a esperança de tais princípios 
serem vividos na prática. Se assim for, as manifestações que escaparam às folhas de papel estarão à disposição do olhar atento do pesquisador-observador.

\subsection{OBSERVAÇÃO}

Enquanto os textos eram produzidos e analisados, a observação ocorria. O pesquisador já era um elemento atuante dentro do ambiente, o que favoreceu sua transição pelos vários locais que compõem a escola (diretoria, secretaria, sala dos professores, sala da coordenação, sala de aula e pátio) sem comprometer a naturalidade cotidiana. $O$ que se mostra como fator precípuo, já que o modo de pesquisa se pauta no desenvolvimento-no-contexto, que busca informações no local em que a pessoa se encontra, dentro das circunstâncias habituais a seu cotidiano, de modo que ela ofereça ao pesquisador suas reais características.

A análise posterior dessas informações fora feita segundo o modelo PPCT (BRONFENBRENNER, 1994, 1996, 2011) e a organização dos dados, em especial, os níveis pertencentes ao contexto (micro, meso, exo e macrossistema). Em cada um desses sistemas, ocorreram fatos importantes e que, entrelaçados, formaram o dia a dia da observação.

Num primeiro momento, não há distinção sobre aquilo que se é observado,

Os pesquisadores vão a campo observar e coletar diversos dados, mesmo os que não se relacionam ao seu tema de pesquisa, para melhor entender o processo, a pessoa, o contexto e o tempo no desenvolvimento humano (PRATI; COUTO; MOURA; POLETTO; KOLLER, 2008, p.163).

Foram as análises posteriores, pautadas no objetivo da pesquisa, que separaram as informações relevantes. No geral, elas foram selecionadas pela capacidade de expor as atitudes cotidianas dos docentes que manifestaram os princípios da interdisciplinaridade - coerência, humildade, respeito, desapego, espera vigiada - e que, assim, poderiam conduzir ao desenvolvimento humano.

Naquilo que toca essa pesquisa, o ponto unificador entre os dois conceitos estava na atitude do professor que o elevasse como pessoa e, consequentemente, como profissional, e que, com isso, transformasse positivamente as pessoas com quem ele convivia - professores e alunos -, bem como ambiente em que se 
encontrava. Essas atitudes interdisciplinares geradoras de desenvolvimento "são aquelas que se mostram contingentes com as capacidades das pessoas e que as fazem ir mais além do seu estado atual" (SALVADOR, 1999, p.169); a busca por elas ocorreu conforme as considerações a seguir.

O cotidiano da pesquisa estendeu-se pelo TEMPO de um ano. O calendário letivo de dois mil e onze (2011) foi acompanhado intensamente pelo pesquisador. O PROCESSO dentro desse período foi proporcionado pelas atitudes e pelas vivências ordinárias, no sentido de repetidas frequentemente, capazes de oferecer uma compreensão da existência (ou não) da interdisciplinaridade e do desenvolvimento humano. Verificou-se, sobretudo, ao longo desse período, situações por demais inesperadas, que exigiram de todos uma resposta imediata, um posicionamento radical, de modo que as verdadeiras identidades se manifestaram.

Todo esse processo desenvolvimental ocorreu por forças que atuaram direta ou indiretamente no ambiente escolar. Considerando esses níveis, a descrição e a análise da observação se deram do ambiente mais distante, o macrossistema, para o mais próximo, o microssistema.

\subsubsection{Macrossistema}

Esse nível do contexto é "definido como padrão global de ideologia e organização das instituições sociais comuns em uma determinada cultura ou subcultura" (BRONFENBRENNER, 2011, p.115) e, se interpretado tendo como epicentro a escola e o docente, os elementos que o constituem são as leis e as regras que ditam a organização e o dia a dia da instituição.

Os documentos que regem o Ensino Médio colocam a interdisciplinaridade como elemento indispensável para a nova construção do saber. Entretanto, é inadmissível pensar que apenas alguns documentos sejam fortes o suficiente para transformar todo um conjunto de atitudes dos docentes corroborado ao longo dos anos. 
benefícios, seja para eles mesmos, seja para os formados, seja para os dois, seja ainda, mais globalmente para a sociedade (LENOIR, 1997, p.9).

Um dos benefícios que podem servir como fator de convencimento encontrouse na questão da qualificação. O contato mais apurado com os professores permitiu conhecer o anseio que alguns têm em relação à continuidade de seus estudos, e há, no macrossistema, as condições para tanto.

Havia constantemente uma crítica ferrenha ao Estado quanto à valorização do professor e à criação de condições melhores e mais dignas de seus trabalhos. Porém, o que não se pode negar é que, se ainda faltam ações concretas a respeito da valorização salarial e do consequente aumento da qualidade de vida do professor, quando mudamos o foco para o item formação, a história começa a se alterar.

O Estado ofereceu, ao longo do ano, uma variedade de cursos e oportunidades para o professor, separados e diferenciados pelos mais diferentes níveis e interesses. São cursos curtos, com poucas horas de duração, que têm como tema a inclusão (tal como o curso de libras) ou cursos mais extensos e elaborados (como a recém-criada REDEFOR ${ }^{12}$, que vale como pós-graduação), além da já existente bolsa-mestrado/doutorado ${ }^{13}$.

A continuidade do aprendizado é um dos fatores decisivos na junção que se faz entre a atitude interdisciplinar e o desenvolvimento humano. Na medida em que amplia a visão do professor, dando base a ele para que possa construir e sustentar suas próprias respostas e teorias, sua atitude se torna uma atitude interdisciplinar; também quando "permite-nos representar o mundo e a nós mesmos de uma maneira cada vez mais ajustada e complexa, podemos dizer que ela é o motor de nosso desenvolvimento" (SALVADOR, 1999, p.149).

Apesar dessa variedade de oferta e do pedido de alguns professores, tal como visto nos textos elaborados (por exemplo, o pedido do PROFESSRO H pela "Preparação dos docentes"), houve grande desinteresse em realizá-los. São sempre os mesmos docentes que se candidatam às ofertas enquanto outros insistem em manter-se afastados dessas oportunidades.

Para se justificarem, afirmam não haver tempo para tanto, que a enorme quantidade de horas trabalhadas e a multiplicidade de escolas necessárias para completar sua jornada impedem qualquer ideia a esse respeito; além daqueles descrentes de que a formação apresente qualquer melhora à realidade em que 
estão. Tais atitudes permitem entender o alerta de que há "muitos colegas que preferem trabalhar quase incógnitos, de maneira mais simples para atingir seus objetivos" (PROFESSOR D).

Eles se deixam tomar pela apatia frente aos obstáculos, sempre existentes para quem continua o caminhar do desenvolvimento. Isso dificulta qualquer adoção de atitudes interdisciplinares, "pois devem ser rompidos paradigmas e superados hábitos enraizados, exigindo a mudança de comportamento de todos os atores" (AGOPYAN, 2011, p. XIII).

Mudança que significa entrar em um caos criativo que, ao obter determinada estabilidade, refaz para melhor o que antes existia e para a qual são necessários "disposição, empenho, colaboração, persistência do professor" (PROFESSOR L). Aquém disso, estavam algumas atitudes docentes que se solidificaram de tal forma, que sua densidade e peso aumentaram tanto a ponto de impedir que o professor dê um passo sequer rumo ao novo, rumo ao futuro.

A grande e positiva surpresa estava nos professores mais novos, imperava neles o ideal de continuar estudando. Sobretudo, os que apresentaram menos do que cinco anos de magistério pensavam em mestrado e doutorado. Dentre esses, já existiam na escola dois mestrandos (excluindo este pesquisador) e um aspirante a mestrando. A relação entre eles era de mútuo encorajamento.

Os que já cursavam o mestrado recebiam apoio para continuar e para completar essa importante etapa. Palavras de incentivo realmente importantes, pois os dois docentes-mestrandos tinham família a quem precisavam também dedicar sua atenção e carinho, sendo que uma das docentes havia dado à luz nos últimos meses de seu curso, necessitando afastar-se por um tempo e estava, a duras penas, retornando.

O aspirante a mestrando, reciprocamente, recebe deles o encorajamento para iniciar o mesmo processo, para que não deixe perder a vontade de aprimorar-se e de continuar a estudar. O que confirma a tese de que, se um membro de uma relação sofre uma mudança desenvolvimental, é provável que o outro também mude (BRONFENBRENNER, 1996).

Um desses trabalhos de mestrado também possui alicerces e objetivos interdisciplinares, trazendo à tona a oportunidade de uma troca intensa de ideias e de questionamentos, que se tornou uma possibilidade real e engrandecedora para o professor-mestrando e para o pesquisador. 
As questões citadas compuseram a análise da influência do macrossitema. Fez-se, então, a necessidade de alterar o foco. Essa transposição de um nível de sistema para outro é denominada de transição ecológica, ela ocorre "sempre que a posição da pessoa no meio ambiente ecológico é alterada em resultado de uma mudança de papel, ambiente ou ambos" (BRONFENBRENNER, 1996, p.22); ou seja, a próxima etapa analisou o docente a partir da relação com um ambiente um pouco mais próximo, denominado exossistema.

\subsubsection{Exossistema}

Elencou-se, por meio das conversas com os professores, que os ambientes que compõem o exossitema são a universidade e a diretoria de ensino. Tanto uma quanto a outra não atuam diariamente dentro da escola, mas uma mudança em suas características poderia refletir positivamente dentro do ambiente escolar.

A universidade, por exemplo, é responsável pela formação do docente e esta, por melhor que seja, é feita de forma disciplinar. Muitos docentes, quando ouvem e discutem sobre a interdisciplinaridade, atestam a questão de que não aprenderam a agir ou a observar a realidade dessa forma mais ampla. Eles acabam por repetir em sala de aula as ações e as atitudes que thes serviram de modelo nos anos anteriores, ou seja, reproduzem todo o ritual disciplinar conhecido.

Toda mudança é ampliada ou incentivada quando existe um modelo inspirador. A simples exposição ao que os outros estão fazendo pode inspirar a pessoa a realizar a mesma atividade sozinha (BRONFENBRENNER, 1996). Quando há um "mestre", para usar o termo de Gusdorf (1987), que demonstre com seu exemplo muito mais do que com teorias, ele inspira outros a que Ihe imitem, ele desafia outros a Ihe acompanharem em sua prática e a Ihe superar. No Ensino Médio, o professor diante do aluno deve ser esse mestre, mas, também ele precisa de um exemplo, que poderia ser (deveria ser) seu professor da universidade.

Esse efeito dominó positivo, que pode transformar as atitudes docentes e, com isso, fazer do ambiente em que atuam locais de desenvolvimento, deveria começar no próprio curso de graduação. 
É certo que as mudanças nas práticas de formação por parte dos formadores são a primeira condição para mudanças nas práticas dos professores. É ilusório pensar, a menos que se acredite em milagres, que uma transformação importante nas práticas de intervenção dos professores possa ocorrer sem que seja sustentada por uma formação (LENOIR, 1997, p.7).

Não se espera uma receita pronta para a aplicação e o exercício da interdisciplinaridade, até porque, ela não existe. Contudo, há o entendimento de que quanto antes essa discussão for feita, variadas ações podem emergir e mais rapidamente seus efeitos podem aparecer. Se a atitude interdisciplinar encontrar seu espaço na universidade, é possível acreditar que seu alcance chegará à escola básica.

Toma-se, como outro exemplo, a atuação da diretoria de ensino. No período da pesquisa, a inserção dela dentro da escola, diretamente com os professores, foram pontuais. Enviaram representantes no planejamento escolar, ocorrido nos primeiros dias do ano letivo, e no replanejamento, realizado ao final de julho, após o recesso escolar, além de outras duas ocasiões por solicitação da escola.

Essa atuação, ainda que a distância, alterou o ambiente, permitindo que se fizesse uma análise que infelizmente indicou a falta de diálogo entre a diretoria de ensino e os professores, a dificuldade de uma parceria efetiva entre ambas, pois, a humildade que prepara a todos ao diálogo, o respeito baseado na alteridade, o desapego que permite a reciprocidade, além da espera e do reconhecimento, desapareceram nesse período.

O fato aludido ocorreu nos quatro meses finais de 2011. A diretoria de ensino enviou à escola o comunicado de que haveria mudanças em algumas escolas da cidade, incluindo aquela. A unidade perderia gradativamente o Ensino Fundamental e se tornaria, após três anos, uma escola exclusiva de Ensino Médio. A notícia agitou os professores. Muitos ficariam extremamente prejudicados e mesmo os que trabalham com o Ensino Médio não sabiam o que poderia acontecer, pois não havia demanda na comunidade para se formar uma escola com tais características.

Independentemente de certa ou errada, a decisão da diretoria de ensino permitiu vislumbrar a identidade de alguns docentes. Eles, que até então sempre foram quietos, até mesmo passivos, quando se viram com uma causa a lutar, mostraram sua opinião, deixaram transparecer suas ideias, impedindo que qualquer alteração fosse feita. A identidade desses despertou, e eles a colocaram em prol da escola e o resultado dessa "libertação" não os abandonou. 
Após esse episódio, o respeito conquistado pelos docentes foi visível. As palavras desses pareciam ter um peso maior do que de outros que se mantiveram quietos, ainda que insatisfeitos, diante da alteração. Principalmente, o respeito por si mesmo, o sentimento de pertença parece ter sido restaurado. Entre eles, as parcerias foram favorecidas, a confiança e o diálogo se efetivaram, construindo um vínculo maior do que o descrito pela profissão em comum.

Em compensação, a relação com a diretoria de ensino ficou abalada. $O$ vínculo entre eles tornou-se pragmático, restrito ao que é necessário. O que diminui para ambos um trabalho conjunto, que traria benefício para todos, principalmente, para a comunidade.

\subsubsection{Mesossitema}

Os sistemas anteriormente avaliados têm em comum a ausência direta da pessoa em análise. Os dois próximos - mesossistema e microssistema - mostram o contrário, o docente se relaciona com ambos, sendo que o meso "compreende as ligações e os processos que ocorrem entre dois ou mais ambientes, os quais contêm a pessoa em desenvolvimento" (BRONFENBRENNER, 2011, p.176).

Nesse momento, apresenta-se uma das observações mais negativas de todo o estudo. A definição acima pouco diz da realidade escolar quando o assunto recai sobre a relação entre escola e família. O que poderia e deveria ser uma parceria positiva, fundamentada em anseios comuns, em objetivos semelhantes, de ajuda mútua e complementar em suas distinções entre escola e família, pouco acontece.

A escola, o professor e a família, que deveriam ser parceiros no auxílio do desenvolvimento dos jovens (formando uma relação digna de ser caracterizada como um mesossistema), pouco se conhecem, em quase nada atuam conjuntamente, colocando a perder um dos maiores instrumentos de transformação.

Comumente, o que é ensinado e aprendido nas famílias não é considerado nas escolas; às vezes, parte-se do zero, como se não houvesse bagagem prévia; em outras, observa-se um certo menosprezo à capacidade educativa dos progenitores. Às vezes, não se considera o fato de que cada família - e cada aluno - é diferente e que as aprendizagens construídas na escola serão feitas sobre a base já construída anteriormente, que podem ser diferentes (SALVADOR, 1999, p.185). 
Qualquer informação vinda dos pais sobre o jovem que auxilie o professor em sua função perde-se nessa falta de comunicação. Também o auxílio que o professor poderia dar aos pais ao observar mudanças de comportamento, dificuldades cognitivas, emocionais, sociais, não se efetivam.

Dentro da escola, pouco se fala dos pais, não se anseia por eles. Existem apenas alguns momentos específicos para que pais determinados estejam lá dentro, como, por exemplo, a reunião de conselho de classe (geralmente organizada para resolver a punição a algum aluno) ou as reuniões de Associação de Pais e Mestres (quando é exigida por lei a participação deles na decisão do uso de verbas públicas destinas à escola). A dificuldade dessa relação manifestou-se de diversas maneiras.

A primeira delas mostrava-se na dificuldade institucional em colocar lado a lado para conversar pais e professores. Não existe um momento apropriado ou reservado para isso. O professor enquanto está na escola, está na sala de aula, impedido assim de dialogar com o pai. Essa responsabilidade acaba nas mãos do coordenador pedagógico, que não tem a informação completa sobre o aluno.

Quando se faz referência à necessidade de uma relação construtiva e
estável entre a escola e a família, destaca-se a conveniência, primeiro, do
conhecimento mútuo e, segundo, da possibilidade de compartilhar critérios
educativos capazes de limar essas discrepâncias, que podem ser
empecilhos para a criança (SALVADOR, 1999, p.184).

Não existe relação construtiva entre escola e pais, porque em muito não há oportunidades para essa relação. Por mais boa vontade que o coordenador pedagógico tenha, ele não conhece o aluno tanto quanto o professor. Em muitos casos, ele apenas detém a informação fragmentada oferecida pelo docente (geralmente uma dificuldade de comportamento) ou alguma descrição do jovem que se encontra nos livros de registro da escola (ocorrências, notas).

Essa carência faz chamar em alto brado pela atitude interdisciplinar. $O$ professor, em busca de novos conhecimentos e de soluções para os desafios que se apresentam, não pode se esquivar às parcerias; e elas só existem "cuando un grupo con el que se va a trabajar, tiene incorporada la premisa de que ninguna forma de conocimiento es en sí misma exclusiva" (MENÉNDEZ, 2002, p.157)

"Não podemos esquecer que trabalhar sozinho nos dias de hoje é um retrocesso" (PROFESSOR G) e que a parceria não acontece só entre professores ou com teóricos. Ela se faz com todos os que participam da escola, o que inclui os 
alunos e os pais dos alunos. Negar algum deles é afastar-se de qualquer atitude interdisciplinar e o pior é afastar-se de qualquer resposta realmente verossímil.

Evitar tamanho equívoco está na incorporação da visão agregadora de quem opta por uma atitude interdisciplinar. "Um olhar interdisciplinarmente atento recupera a magia das práticas, a essência de seus movimentos, mas, sobretudo, induz-nos a outras superações, ou mesmo reformulações" (FAZENDA, 1998, p.14). A superação por parte do professor está em abrir-se ao conhecimento dos pais.

Não é mais permitido enxergar os pais como um entrave dentro da escola. Ainda que alguns deles pareçam mais problemáticos que seus filhos (como alegam alguns professores), o simples conhecimento dessa situação já seria importante ao modificar o modo do professor entender e se relacionar com o aluno. Os olhos do professor estão atentos, mas precisam ser complementados pela visão dos pais.

\subsubsection{Microssistema}

Dentro do contexto sobre o qual a pessoa atua, o MICROSSISTEMA é o nível mais próximo. Nele ocorrem relações diretas, face a face, denominadas de processos proximais. Esses processos colocam a pessoa em situações que a questionam, incomodam, fortificam, amparam, ou seja, situações inusitadas às quais deve responder e cujo resultado torna-se desenvolvimento.

\footnotetext{
O desenvolvimento humano ocorre pelos processos de interação recíproca progressivamente mais complexos entre um organismo humano ativo biopsicologicamente em evolução e as pessoas, objetos e símbolos no seu ambiente imediato. Para ser efetiva, a interação deve ocorrer em uma base regular de tempo durante longos períodos. Essas formas duradouras de interação no ambiente imediato são denominadas como PROCESSOS PROXIMAIS (BRONFENBRENNER, 2011, p.202, grifo nosso).
}

Para que os processos proximais auxiliem realmente ao desenvolvimento humano, é importante que o ambiente constitua-se como positivo e colabore para que as relações entre a pessoa e o seu entorno ocorra de modo a produzir transformações positivas em ambos, mantendo seu caráter recíproco.

A efetivação da escola enquanto lugar de desenvolvimento passa diretamente pela atitude de seus professores. Uma atitude a conduzi-los a patamares mais 
elevados de conhecimento e, principalmente, a modifcá-los qualitativamente como pessoa. Quando o professor se desenvolve, seus companheiros e alunos se desenvolvem também. Essa nova e benéfica atitude é a atitude interdisciplinar.

A interdisciplinaridade se deixa pensar, não apenas na sua faceta cognitiva - sensibilidade à complexidade, capacidade para procurar mecanismos comuns, atenção a estruturas profundas que possam articular o que aparentemente não é articulável - mas também em termos de atitude curiosidade, abertura de espírito, gosto pela colaboração, pela cooperação, pelo trabalho em comum (POMBO, 2005, p.13, grifo do autor).

A atitude interdisciplinar docente que fortaleça 0 desenvolvimento foi procurada em todos os espaços da escola em que o professor atua. A observação ocorreu nas reuniões, na sala dos professores, na sala da coordenação, na direção, onde os professores estavam diretamente com seus pares; na sala de aula, nos corredores e no pátio, junto com os alunos; na secretaria diante dos outros funcionários.

Para facilitar a visualização desses dados, uma nova subdivisão foi feita, seguindo três momentos: a relação entre professores (professor-professor e professor-direção-coordenação), a relação entre professores e funcionários e, por último, a relação entre professores e alunos. Com essa conformação, acreditou-se facilitar a análise dos dados, salientando todas as formas de relação existentes na escola - relações entre pares, grupos, amizade, competição, rivalidade, aprendizagem e descoberta do novo, entre tantas outras. A escola pode promover a autoestima e a autoeficácia tanto dos professores quanto dos alunos, capacitandoos em habilidades sociais, além de influenciar o relacionamento entre o grupo de iguais por meio de normas, regras (POLETTO; KOLLER, 2008), para tentar encontrar nela as manifestações da atitude interdisciplinar.

7.1.4.1 Relação entre professores (professor-professor e professor-direçãocoordenação)

A ação inicial estava em conversar com os diretores. Explicar-lhes detalhadamente a opção em voltar a estudar, apresentar o projeto e apontar a necessidade da pesquisa de campo e do interesse em realizá-lo naquela escola. 
Com enorme prazer, ouviu-se deles o consentimento para o trabalho. Suas palavras eram uma mescla de incentivo diante dessa opção pelo aprimoramento e de admoestação quanto ao baixo números daqueles que optam por essa continuidade.

Associar imediatamente essa reação ao trabalho era inevitável. O respeito e o reconhecimento demonstrado dentro da sala da direção despertaram grandes expectativas de que as manifestações vivenciadas ali pudessem se ampliar ao longo da pesquisa. A aceitação rápida e sem obstáculos da proposta oferecida foi um primeiro reconhecimento do foco de atitude interdisciplinar.

A parte seguinte estava em juntar-me aos colegas para o início do planejamento escolar. Ali foi o momento escolhido para apresentar aos professores a proposta da pesquisa. Convencer dois membros da direção não havia sido difícil, agora era preciso convencer os 15 efetivos que constituiriam parte direta da pesquisa. Como a pesquisa se direcionaria a apenas uma parte dos professores, o convite a que participassem foi feito individualmente, nos momentos livres do planejamento.

Em cada intervalo, algum professor era esclarecido e convidado. Também junto deles a resposta foi positiva. Sem exceção, teceram elogios e colocaram-se prontamente à disposição para qualquer ajuda. Porém, o início promissor deu lugar a um aspecto negativo. A distinta pesquisa, além da observação por parte do pesquisador, segue com a necessidade de que os docentes escolhidos apresentem sua compreensão a respeito da interdisciplinaridade. Por isso, foram convidados a escrever, sem auxílio de pesquisa, o que sabiam sobre o tema.

As palavras de elogio e de disposição dadas anteriormente sofreram um abalo quando os itens solicitados tardavam a ser entregues. Os professores ficaram à vontade para a construção do material solicitado, podendo ser realizado na escola, em seus momentos sem aula ou no HTPC $^{14}$; alguns solicitaram a possibilidade de realizá-los em casa, o que poderia ser feito sem nenhuma espécie de problema. $A$ dificuldade estava no cumprimento dessas tarefas por parte dos docentes. Enquanto um número reduzido os entregou prontamente, outros não o faziam. A insistência era constante por parte do pesquisador, e a promessa de entrega por parte dos docentes, também. Ao final da pesquisa, doze professores atenderam a solicitação.

Essa desconsideração perante a solicitação alheia, distante da coerência entre as palavras proferidas livremente pelos docentes no momento do convite para a pesquisa e as ações que se seguiam, conta como fator negativo junto as análises 
necessárias. O princípio da coerência e do respeito e os valores como a alteridade, o reconhecimento e a reciprocidade, tão importantes na relação entre atitude interdisciplinar e desenvolvimento, perderam um pouco de sua consistência.

Contudo, o número de doze participantes (80\%) que atenderam a solicitação, contra apenas três (20\%), permite uma análise positiva. Esse compromisso com o outro, essa participação ativa nos projetos alheios, essa disposição em colaborar permite que parcerias sejam feitas. Parceria que "deriva da afetividade e do respeito, atributos próprios da interdisciplinaridade, que por sua vez implica participação e colaboração mútua" (JUSTINA, 2002, p.160).

Outro aspecto positivo se manifestou logo nos primeiros dias de observação. A atitude registrada apresentou traços de HUMILDADE ao permitir que a pessoa do coordenador dialogasse com um dos professores. Houve, como consequência disso, o RESPEITO pelo trabalho alheio, pelo conhecimento que ele podia partilhar; houve o reconhecimento das necessidades e do sentimento alheio, o DESAPEGO pelo próprio conforto e tranquilidade pelo atendimento às carências alheias.

A análise acima se tornou concreta em uma ação da coordenadora pedagógica: os primeiros passos do ano letivo correm no sentido de uma ordem escolar vivenciada principalmente na distribuição das aulas e nos seus devidos horários. Esse aspecto está ligado ao funcionamento intrínseco da escola, ao seu microssistema, pois a distribuição precisa ser realizada o mais rápido possível, visando ao bom andamento da escola e da vida do professor, mas também está influenciando e é influenciada de maneira extrínseca, em seu exossistema, quando a construção desse horário esbarra na elaboração do horário de outra escola e na necessidade de alguns professores conciliarem sua atuação em dois diferentes ambientes.

Algumas escolas, frente ao impasse criado pela dificuldade de assumir os diferentes horários a que o professor se submete, optam pela saída mais fácil: forçar o professor a abandonar tais aulas, negando-se a modificar o horário que anteriormente fizeram. Vários foram os professores que apareceram na escola com esse problema. Em outras instituições, esqueciam-se da necessidade do professor em trabalhar, do respeito e do reconhecimento que ele merece ante seus anos de profissão e das dificuldades que se apresentam para o exercício de sua função.

Diante desse impasse, a coordenação da escola, responsável pelo horário, assumiu a tentativa de auxiliar todos aqueles que precisavam. Mesmo ciente do 
enorme trabalho que seria mudar o horário já estabelecido, ela entendeu a necessidade do professor e, após tanto esforço, o resultado foi positivo. Essa atenção dada aos professores permitiu um ambiente de maior confiança e de disponibilidade entre eles. Os que foram atendidos tornaram-se os primeiros a defender a coordenação e a mobilizar seus pares para que assumissem diversas propostas dadas por eles.

O valor desse exemplo está em apresentar fatores que se procura numa atitude interdisciplinar. Nesse caso, de alguém que enxerga no outro as necessidades em questão, aceita-as como sua e abandona seu conforto para em conjunto buscarem solução. Nesse caminho, constrói-se um ambiente favorável para muitas outras atividades, cria-se um comprometimento que transcende a atividade docente e se corrobora na relação pessoal. Com isso, as relações se elevam ao ponto de construírem um ambiente de desenvolvimento tanto pessoal quanto coletivo. Isso baseado na concepção de que:

É esperado que as figuras com quem o ser humano se relaciona face a face se revelem disponíveis, com a capacidade de mobilizar afetos positivos na interação. Esse aspecto é importante, na medida em que a qualidade relacional será um importante atributo para o desenvolvimento futuro (DINIZ; KOLLER, 2010, p.70)

Após esse acontecimento, o ambiente entre a coordenação e os professores se fortaleceu. Os professores passaram a se sentir mais seguros, mais amparados, o que Ihes deu mais confiança para partilhar questões sobre a escola e sobre a prática docente. Parece que o fato ocorrido abriu as portas para as trocas de ideias que conduzem ambos ao desenvolvimento.

Essa atuação conjunta favoreceu outros momentos decisórios. Os assuntos a respeito dos rumos a serem tomados, tanto de cunho pedagógico quanto administrativo, geralmente discutidos nos HTPC's, que exigem participação de todos, tornaram-se mais ativos e, mesmo que ainda haja falhas nesta relação, a oportunidade de trazer para o contexto escolar uma relação mais democrática e participativa é muito grande.

Ao se criar oportunidades para que todos participem, eleva-se a responsabilidade de todos para com o projeto instituído. Como quer a interdisciplinaridade, a participação constrói e fortalece um sentimento de pertencimento, que resulta no assumir das ações e das consequências que disso provém. $O$ efeito dessa ativa presença se dá pelo cuidado, em que cada um se 
sente realmente responsável pelas coisas que acontecem nesse meio, até porque muitos desses acontecimentos estão ligados às decisões e às opiniões que esse mesmo indivíduo ofereceu.

Esse movimento conjunto rumo ao novo é também exemplo de atitude interdisciplinar e ele só pôde germinar quando os professores formaram um vínculo entre si. A atitude do coordenador para com os problemas do professor e o já citado enfrentamento dos professores ante as mudanças previstas pela diretoria de ensino foram situações que criaram tal vínculo. Isso foi muito importante, porque essa relação os incentivou a serem verdadeiros consigo mesmo e com os outros e, assim, partilhar tudo aquilo que pensam. Essa disponibilidade, essa cumplicidade, permitiu que se aventurassem pelo novo, que optassem pelo desafio do desconhecido, dado a consciência de que assumiam juntos qualquer responsabilidade pelos resultados obtidos.

Os exemplos citados criam um ambiente positivo, reforçam a valorização do outro, contudo, eles são ainda pequenos lampejos de uma atitude interdisciplinar. Para que isso seja considerado um desenvolvimento por parte do professor, elas precisam se repetir mais vezes, o que não aconteceu. A junção que devolve a completude ao saber ainda acontece pouco. Algumas tentativas foram feitas, houve discussões de temas comuns, sessões de filmes e debates, trabalhos extraclasse em comum, mas, nenhum deles ainda conseguiu romper a barreira da multidisciplinaridade.

Há realmente muita dificuldade para a adoção da atitude interdisciplinar dentro da escola. Os professores não têm um momento para conversarem, para montar planos conjuntos. O coordenador, que poderia ser o motivador dessa ligação, está sempre ocupado com a burocracia; os horários fixos somado ao número excessivo de aulas assumidas pelo docente formam uma barreira a dificultar qualquer contato entre os docentes.

Ainda que a realidade seja assim, isso não é desculpa. "Cabe a ele [o professor] atestar, por sua atitude global, que não é uma vítima passiva do sistema de que é prisioneiro" (GUSDORF, 1987, p.38). Se a atitude interdisciplinar é realmente importante ao docente, ele precisa se empenhar mais, buscar realmente o outro e construir com essas parcerias, conhecimentos e verdades. 
7.1.4.2 Relação entre professores e funcionários

Além da relação entre a coordenação com os professores, pode-se observar a interação entre os docentes e os demais funcionários dentro da unidade escolar. Esse nível de relação dificilmente apresentou elementos aos quais podemos classificar como de atitude interdisciplinar. Ao contrário, professores e funcionários parecem formar guetos diferentes dentro da escola. Apesar de a instituição constituir um todo onde cada um, no exercício de sua função, contribui ativamente para a construção de um ambiente propício para o aprendizado e também para o desenvolvimento humano, as relações que permitem essa construção são deficitárias, principalmente, na relação entre o corpo docente e os cargos outros.

A impressão que se tem é a de que a escola está dividida entre aqueles que simplesmente lecionam e aqueles que cuidam da burocracia escolar. Não há interação entre eles. Em nenhum momento se privilegia o contato, a troca de ideias, o trabalho conjunto entre ambos. Como se um não pudesse colaborar com o trabalho alheio.

Os professores não parecem interessados nas informações e nos conhecimentos que esses outros funcionários têm a oferecer. As diferentes formações e os níveis de estudo pareciam criar um distanciamento alto apesar de ambos trabalharem em prol do mesmo objetivo. Há, nesse sentido, um aspecto negativo, tal como aquele vislumbrado na relação entre os docentes e as famílias dos alunos.

Tanto os funcionários quanto os pais dos alunos (e os funcionários são pais de alunos) parecem estrangeiros na educação; são tratados como se não entendessem a cultura escolar nem o afazer docente, como se a linguagem que carregam fosse diferente da linguagem dos professores.

Infelizmente, há o esquecimento de que

Só há interdisciplinaridade se somos capazes de partilhar o nosso pequeno domínio do saber, se temos a coragem necessária para abandonar o conforto da nossa linguagem técnica e para nos aventurarmos num domínio que é de todos e de que ninguém é proprietário exclusivo (POMBO, 2005, p.13)

A reunião de planejamento, por exemplo, espaço que poderiam estar unidos todos os que compõem a escola para discutir possibilidades para o ano que se 
inicia, fica restrita apenas aos docentes, excluindo secretários, agentes escolares e pais de alunos. Essa segregação se amplia nos afazeres do dia a dia. Alguns docentes ficam a acusar tais funcionários de negligenciarem seus pedidos, de não cumprirem bem suas funções. Enquanto os funcionários, apoiando-se em desculpas como o excesso de trabalho e a falta de tempo, seguem sua rotina habitual.

A direção, que poderia oferecer qualidade a essa interação, em alguns momentos, parece ter pouca força para alterar essa realidade. Assim, o efeito que se cria é ruim a todos os que ali estão. A direção se sente inoperante em relação à secretaria, esta não atende aos professores e estes não cansam de apontar seu descontentamento a respeito da situação.

Nesse quesito, que reflete a situação organizacional da instituição escolar, há a percepção de que a escola atua dentro de um espaço geográfico comum, mas essa proximidade não se concretiza numa relação construtiva que amplie os horizontes de cada repartição. Perde-se noção de que todos podem e devem contribuir para o andamento escolar.

A relação entre professor e funcionários se dava da mesma forma. Estavam presos na rigidez de sua função, incapazes de ajudarem-se mutuamente. A troca de ideias, o debate e o diálogo exigem pontos de vistas diferentes e isso acontece muito pouco ou quase inexiste. Não há a consciência de que, em diversos momentos, as respostas de que se precisa, as ações que são necessárias estão junto daqueles que olham as coisas por um outro foco, livre das amarras e das alienações que a repetição de uma mesma função podem oferecer.

O ambiente escolar, ao seguir atuando separadamente por repartições e por funções, oferece a construção de uma instituição de modelo mecanicista. Cada um é uma engrenagem, necessária dentro do funcionamento cotidiano, mas que mantém pouca interatividade entre si.

\footnotetext{
Quando um engenheiro projeta qualquer máquina, a tarefa é definir uma rede de partes interdependentes, arranjadas dentro de uma seqüência específica e apoiada por pontos de resistência ou rigidez precisamente definidos (MORGAN, 1996, p.29).
}

Cada parte desta máquina executa uma única função e, quando esta não o faz com qualidade, é substituída separadamente. No caso de uma instituição pública, isso é um pouco mais difícil, dado a obtenção dos cargos por meio de concurso, garantindo uma estabilidade profissional, em nada relacionada à 
qualidade do trabalho; o que faz com que a máquina escolar opere aquém de potencial.

Por mais que se reconheça a importância da participação de todos, isso ainda soa como utopia. Não houve manifestação alguma, em nenhum momento, por parte dos professores, pela presença de alguém da secretaria. Nem tão pouco os agentes escolares manifestaram interesse em participar daquela reunião.

Essa fragmentação da escola, por mais que seja em sua organização, atrofia um conceito importante dentro da interdisciplinaridade, o conceito de "outro".

A interdisciplinaridade resgata a importância do "outro" na relação de aprendizagem, já que é a partir da troca mútua que se constrói e reconstrói o conhecimento na comunidade de aprendizagem (LUZZI; PHILIPPI JR, 2011, p.132).

Porém, dentro da escola, o "outro" parece ser simplesmente os professores.

\subsubsection{Relação entre corpo docente e alunos}

A atitude interdisciplinar ajuda o professor a se desenvolver. Ele se refaz enquanto pesquisador, transformando suas indagações em pesquisa, contribuindo, assim, para a explicação da realidade que nunca há de ser completa sem sua participação. Ao buscar as respostas de que necessita, ele consulta os livros, ampliando seu conhecimento, mas, principalmente, ele consulta a si mesmo e à sua própria história, aumentando sua confiança em si mesmo, sua autoestima.

A busca pela verdade é um desafio maior do que qualquer pessoa solitariamente pode enfrentar,o que indica que mais perto da verdade se chega quanto mais pessoas puderem se unir, a fim de que suas visões, sempre indispensáveis e insubstituíveis, possam formar um todo complexo e real. Quando o professor torna suas atitudes interdisciplinares, ele está, ao mesmo tempo, recuperando aspectos de sua autoestima, que foram provocados pelo sucateamento a que sua profissão o conduziu. O professor, quando dá início a essa nova forma de atitude, contagia toda a sala de aula, a escola e a comunidade (FAZENDA, 2005).

É como exemplo, é como aquele que inspira e contagia a sala onde se põe. Os professores auxiliam seus alunos em sala de aula, dividindo com eles o conteúdo 
que possuem, construindo com eles novos saberes, mas, sobretudo, os professores os ajudam com sua postura, com seu modo de ser.

Os adultos orientam, desafiam, proporcionam modelos de comportamento a serem modificados e organizam e estruturam a participação da criança (e do jovem) em atividades. Em resumo, os adultos são "incentivadores cognitivos", estimulando e orientando as crianças (e jovens) para que sejam tudo o que podem ser (FLAVELL; MILLER; MILLER, 1999, p.20)

Esse trabalho não é simples. O professor encontra na escola alunos com todos os tipos de personalidade. Alguns são estudiosos e empenhados, portam-se com mais educação, enquanto outros manifestam desinteresse e atitudes questionáveis, em suma, é um ambiente representativo das escolas atuais. Respeitando os problemas existentes em todas as escolas com relação aos discentes e às idiossincrasias que apresentam, essa diferença tem, dentre muitos fatores, as condições econômicas e familiares que resultam muito na própria herança cultural que carregam.

Essas singularidades estão no consciente dos professores, principalmente, no dos efetivos que se encontram na escola há bastante tempo. Essa longevidade dentro da instituição permite que alguns professores acompanhem os alunos desde as séries primeiras, conhecendo sua postura dentro da escola e também suas ações fora dela, estando realmente lado a lado com eles em seu processo de amadurecimento intelectual e humano.

Tanto tempo juntos permite ao docente conhecer as dificuldades de aprendizado que essas crianças e jovens carregam, tanto quanto compreender os desafios que formam sua vida fora da escola. O manuseio dessa informação pode ser analisado de duas formas distintas.

A primeira apresenta um cunho pessimista. Há um distanciamento muito grande de alguns professores em relação a esses problemas exteriores ao ambiente escolar. Eles têm plena consciência da dificuldade que os alunos trazem de suas casas, mas querem apenas preocupar-se com o resultado deles em sala de aula, acreditando ser possível a separação entre vida familiar e vida escolar.

No que toca o dia a dia, geralmente, são esses professores mais distantes que apresentam relações mais problemáticas com suas salas. O domínio sobre os jovens é relatado por eles como difícil. Talvez porque lhes falte uma aproximação que não está em sua grande parte no interesse pela teoria, mas pela partilha de sua 
história de vida, das dificuldades, dos desafios, da esperança. Quando o professor se fecha a esse aspecto, fecha-se para qualquer outro.

Para esses, a sala dos professores, na hora do intervalo, transforma-se num refúgio a protegê-los dos alunos, também em um espaço de acusações, de extravasar os sentimentos que pela postura de sala de aula não seriam permitidos. Há dias em que o que se ouve sobre os alunos é que são da pior espécie possível e que não há soluções para muitos deles; que para estes, o estar na escola significa fugir de casa, pois qualquer coisa relacionada ao estudo não lhes interessa.

A representação destes taxados "alunos-problemas" acaba tomando todo o espaço da discussão, generalizando a ponto de criar a impressão de que todos os que ali estudam têm este perfil e que não há nada o que se possa fazer por eles, que não merecem qualquer esforço, pois o que foi feito para eles, eles não aproveitaram. Assim, são tidos como descartáveis e que, enquanto não Ihes forem impostos outros ambientes, continuarão a colocar a perder os "poucos" que se interessam por algo.

Dessa atitude podemos pensar que

Muitos homens ensinam - uma disciplina intelectual ou manual, uma
técnica, um ofício -, poucos desfrutam esse acréscimo de autoridade que
lhes advém, não de seu saber ou capacidade, mas de seu valor como
homem. Nesse sentido, um artista, um artífice, um homem de estado, um
chefe militar, um sacerdote podem ser tão bons ou melhores mestres para
aqueles que os cercam do que certos professores. A vida de tais homens
impõe-se, a todos ou a alguns, como uma lição de humanidade
(GUSDORF, 1987, p.3).

O modo de pensar impede qualquer relação frutuosa com o aluno. Mais do que isso, impede que se formulem opções para auxiliá-lo. Há o distanciamento entre professor e aluno, sendo que o único vínculo existente entre eles está numa degradada relação ensino-aprendizagem baseada na imposição de conteúdo.

Relações problemáticas ajudam a identificar no professor uma indisposição muito grande em relação ao seu ofício. Consequência disso está na repetição constante de ideias como "necessidade de buscar um novo emprego" ou "não vale a pena estudar, o que sei é mais que suficiente para o público que temos" ou ainda "eles são incapazes de cobrar algo a mais de mim". Há nessas palavras um desânimo muito grande, que se reflete no próprio desinteresse em continuar se atualizando. O sentido da ação docente e a necessidade que ela carrega de 
continuar a aprender encontram, na relação desfigurada entre professor e aluno, um fator desmotivante.

Essa indisposição também aparece no lado do aluno. As brincadeiras de mau gosto, ou mesmo o puro desgosto por determinada matéria, têm como objeto do escárnio os professores com quem têm pior relacionamento.

O contrário também existe, e os professores que despendem parte do seu tempo a estar com os alunos, a conversar assuntos outros, diferentes dos conteúdos programados, ganham um reconhecimento muito grande. Ao ponto de, mesmo os que apresentam dificuldade de aprendizado, enxergar no professor alguém digno de respeito. Isso faz pensar na oportunidade de realizar um ensino que valorize o conhecimento, mas, principalmente, que valorize a vida e a pessoa.

O estabelecimento desses laços recíprocos mobiliza o jovem para 0 desenvolvimento de atividades no seu meio físico, social e simbólico, condutores da sua atividade exploratória, manipuladora, criativa e imaginativa (DINIZ; KOLLER, 2010). Um dos professores pode servir como exemplo a essa constatação.

Em determinado momento do ano letivo, esse professor apresentou problemas na coluna. Tirar licença seria um transtorno maior a ele dado alguns fatores de seu mesossistema. Frente a essa situação, os alunos apresentaram-se como verdadeiros companheiros desse professor. Auxiliaram no manuseio dos materiais, cada um "tomava conta" do outro de modo a controlar seu comportamento. Esses alunos tornaram-se mais responsáveis, amadureceram diante da situação enfrentada.

Isso só pôde acontecer, porque, ao longo do ano, o professor e os alunos formaram um relacionamento forte, com muito afeto por parte de alguns. Prova disso é que vários foram os momentos em que seus alunos estavam próximos dele e, ao invés de discutirem teorias, falavam dos problemas em casa, das possibilidades de futuro, da questão de trabalhar ou simplesmente estudar, dos riscos de gravidez para uns, do como ser mãe na adolescência para outras. Toda essa cumplicidade permitiu as ações citadas. No final do ano letivo, no conselho final, esse professor apresentou poucos problemas com reprovações.

Outro exemplo de atitude que conduziu a bons resultados estava na atuação de um dos professores readaptados (não pode exercer sua atividade em sala de aula). Uma das funções desse professor está na ornamentação de todo e qualquer evento dentro da escola. Interessante notar que muitos alunos, por prazer, o ajudam. 
Por não haver nenhuma cobrança sobre esses alunos, por não haver avaliações, nem tão pouco notas, os jovens oferecem o que tem de melhor. Sentemse a vontade para ousar. Isso representa, por exemplo, que alguns deles realizam desenhos, cartazes, painéis muito melhores do que aqueles que apresentam na aula de artes. A organização que demonstram, a desenvoltura em lidar com conhecimentos diferentes é melhor do que as vistas nas disciplinas. É impossível, diante desses exemplos, desconsiderar que "cada membro de um microssistema influencia o outro" (BRONFENBRENNER, 2011, p.187), principalmente, quando a relação entre eles é de respeito, de reconhecimento. É assim que os processos proximais podem produzir como efeito:

competência, que se refere à aquisição e desenvolvimento de conhecimentos, habilidades e capacidade para conduzir e direcionar seu próprio comportamento através de situações e domínios evolutivos, tanto isoladamente como através de uma combinação entre eles (intelectual, físico, sócio-emocional, motivacional e artístico) (CECCONELLO; KOLLER, 2003, p.516)

Outra questão que serve como exemplo aos alunos está na leitura. Alguns dos professores passeiam constantemente com livros pela escola, mostram o que estão lendo, conversam sobre os títulos, servindo assim de espelho tanto para seus alunos quanto para seus colegas. A prática ainda é limitada, mas, como na atitude interdisciplinar, é preciso sempre que alguém aceite dar o primeiro passo nessa direção, que alguém aceite ser o elemento a suscitar a ideia e isso a escola apresenta.

A relação entre professor e aluno é recheada de conflitos e de parcerias. $O$ importante é o professor saber como lidar com elas. Em tudo o que foi observado, nada parece registrar mais efeito do que o exemplo. O professor que estuda (tal como os mestrandos), o professor que lê, aquele que não falta tem um respeito conquistado junto aos discentes.

Os professores que mantêm esse bom relacionamento apresentam perspectivas interessantes, talvez por conseguirem vislumbrar uma realidade para além de sua única visão. Eles se comprometem com seus alunos, sente com e pelos estudantes, ele planeja e sonha em comunhão com seus aprendizes. Com isso, ambos se desenvolvem. Cada um encontra no outro o apoio para evoluir, 
despertar e de enriquecimento. Rigorosamente, o homem não pode existir no estado de isolamento. O ser humano revela-se no encontro, nesse encontro que é, segundo a expressão de Buytendijk, "um ser o que não se é, e um tornar-se o que já se é" (GUSDORF, 1987, p.139).

As observações terminaram no mesmo dia em que se encerrou o ano letivo. Com as férias dos alunos e o descanso dos professores, a escola se esvazia e o ambiente se torna infértil para as manifestações que interessavam a essa pesquisa. Ao cabo do ano de observação, muitas manifestações ocorreram, muitas atitudes foram realizadas. Todas essas ações exigem uma conclusão, porém, todo trabalho que lide com pessoas não tem fim. As pessoas mudam, elas surpreendem. Adotam posturas e as alteram, elas inovam. Mesmo assim, é preciso parar para partilhar os dados obtidos. Parte-se, agora, para as considerações finais. 


\section{CONSIDERAÇÕES FINAIS}

O início desse trabalho estava fortemente marcado pela crença de que a interdisciplinaridade é um elemento propulsor do desenvolvimento humano dentro da escola. Em especial, a vertente fenomenológica, fundamentada nos princípios da humildade, da coerência, do respeito, do desapego e da espera vigiada (FAZENDA, 2002) e unida a valores como o diálogo, a alteridade, a reciprocidade e o reconhecimento, tende a exaltar a pessoa, conduzindo-a a patamares cada vez mais elevados, constituindo-se em desenvolvimento.

No anseio de provar a veracidade de tal ideia, um trabalho conceitual foi elaborado e uma pesquisa de campo desenvolvida. Tudo isso no intuito de atender a todos os critérios das ciências, sejam elas quais forem, ou seja, há uma construção teórica fundamentada naqueles pensadores que se destacaram na discussão sobre interdisciplinaridade e sobre desenvolvimento humano. Eles participaram do debate, oferecendo suas visões e auxiliando a corroborar as hipóteses instituídas.

A pesquisa de campo, por sua vez, desejava atender aos critérios da ciência moderna, cuja verdade se assume diante dos fatos e de sua comprovação pela experiência. Ao escolher o ambiente da pesquisa (a escola) e ao solicitar os participantes (os docentes), foi preciso procurar neles a ideia desejada.

Tanto na parte teórica quanto na parte prática da pesquisa, o objetivo era o mesmo: investigar as manifestações da atitude interdisciplinar na prática docente e suas relações com o desenvolvimento humano no contexto do Ensino Médio. Para tanto, foi preciso conhecer o que se procurava, a fim de reconhecê-lo no dia a dia dos professores dentro da escola.

Os resultados dessa busca pela interdisciplinaridade tornada atitude interdisciplinar por força e por vontade do professor são paradoxais. Existe um conhecimento parcial sobre ela, ligado à noção geral da religação entre os saberes. Outras informações, como por exemplo, a existência de diferentes perspectivas (LENOIR, 2005-2006, LENOIR; HASNI, 2004) e a instituição de alguns princípios que norteiam a atitude interdisciplinar (FAZENDA, 2002), aparentemente, são desconhecidas pelo professor. Contudo, tal incompreensão não impediu que algumas manifestações ocorressem, de modo a tornar real a atitude interdisciplinar ainda que não efetivamente. 
Pormenorizar essa afirmação requer, antes de tudo, averiguar a COERÊNCIA entre teoria e prática dentro da atitude docente. Para isso, é preciso reconhecer e valorizar a existência de um conhecimento sobre interdisciplinaridade entre os professores e a unânime opinião entre eles de que ela é uma necessidade na árdua tarefa de construir conhecimento.

No que toca aos docentes,

Entende-se a interdisciplinaridade como garantia de construção de
conhecimento que rompa as fronteiras entre as disciplinas.
Interdisciplinaridade é, nesse sentido, uma maneira de trabalhar o
conhecimento visando à reintegração de dimensões isoladas pela
monodisciplinaridade. Com isso, se pretende alcançar uma visão mais
ampla da realidade, superando a sua fragmentação (LUZZI; PHILIPPI JR,
2011, p.127).

No entanto, a compreensão existente sobre interdisciplinaridade não é suficiente para torná-la efetiva dentro da escola. O discurso dos professores a exaltar essa nova forma de atitude não condiz com suas práticas cotidianas, baseadas na antiga e cristalizada preocupação exclusiva com sua área do conhecimento.

Há, em alguns momentos, a tentativa de superar essa fragmentação. No entanto, os esforços não apresentam características interdisciplinares. O que se vê é a busca por um trabalho coletivo em que cada um dos professores oferece, em sua aula, o conhecimento que sua disciplina despende sobre determinado assunto. As ações adotadas não solicitam uma interação que conduza à troca direta de ideias, as estratégias não criam parcerias que procuram entender a verdade como una, ainda que vista sob diversas perspectivas.

$\mathrm{O}$ trabalho conjunto que abre os diferentes saberes uns aos outros ainda não existe. $O$ diálogo entre as disciplinas que propicie uma interação entre os distintos métodos que as constituem, entre os conceitos que as caracterizam e cujo resultado seja uma resposta única a apresentar realmente a verdade ainda é falho; a tentativa de mostrar a complexidade da realidade é nula.

A fragmentação do conhecimento, representado pelas diversas disciplinas, ainda prepondera na escola de modo que os professores apresentam o mesmo objeto como se fossem diversos. Não existe um verdadeiro diálogo a fim de encontrar a unicidade perdida. Fala-se muito em interdisciplinaridade, salientam demasiadamente sua importância, pena que o cotidiano não consiga ultrapassar a prática multidisiciplinar. 
Quando se amplia a busca em prol de conhecimentos mais detalhados sobre a interdisciplinaridade, o resultado é ainda mais pessimista. Qualquer alusão às diferentes vertentes que a orientam parece ser desconhecida do grupo de professores. Não existe nenhum comentário direto sobre a perspectiva francesa, que orienta a interdisciplinaridade pelo caminho epistemológico e conceitual, desejosa por construir uma super ciência, mesmo sendo ela a base da compreensão dos professores.

Tão pouco existe alguma menção à vertente americana, representante de uma interpretação pragmática da interdisciplinaridade, direcionada a resolver problemas técnicos ou sociais de maneira mais eficaz, cuja presença se manifesta nos países influenciados diretamente pelos Estados Unidos, o que inclui o Brasil.

Diante do desconhecimento das duas grandes vertentes que orientam com maior força a atuação interdisciplinar, qualquer expectativa por um comentário que defina e reflita sobre a perspectiva brasileira, fundamentada na experiência subjetiva do professor, parece impossível.

Não há um simples comentário que lembre qualquer dos princípios da interdisciplinaridade. A retomada da característica do professor enquanto pesquisador, disposto a colocar à disposição todo seu conhecimento construído pela experiência cotidiana e, com isso, debater com os teóricos que organizam à distância a prática pedagógica, não parece ser objeto de desejo da maioria dos que divagaram sobre o assunto. Tanto que a opção pela interdisciplinaridade, ao ser descrita pelos docentes, tinha como objetivo auxiliar o aluno (a enxergar a totalidade do mundo, a complexidade do real...) e não o professor.

A impressão recebida é que os professores já se consideram como praticantes da interdisciplinaridade. Ao apontarem os benefícios dela aos alunos, deixam entender que suas atitudes já se caracterizam como interdisciplinares e, por isso, estão prontos para orientar seus alunos por essa nova forma de construir conhecimento.

Um quadro ainda incipiente como esse parece negar a problemática da pesquisa e seu objetivo principal. Quanto menos a interdisciplinaridade aparecer, menor é a possibilidade de ligá-la ao desenvolvimento humano.

Entretanto, apesar do conhecimento teórico deixar lacunas importantes sobre esse conceito, a vivência cotidiana permite que se tenha esperança ao manifestar, em várias ações, o sêmen da atitude interdisciplinar. 
Há algumas manifestações que expressam diretamente o princípio da humildade, do respeito, do desapego e da espera vigiada (FAZENDA, 2002) e, quando eles aparecem, o resultado transcende ao puro aprender, permitindo que o professor e os que atuam com ele atinjam um patamar mais elevado, conhecido como desenvolvimento.

É assim quando alguns professores abandonam qualquer falsa superioridade diante dos seus pares e de seus alunos e, com HUMILDADE, unem seus conhecimentos. Muitas vezes, esse conhecimento não se relaciona diretamente aos saberes de suas disciplinas, referindo-se muito mais à questão de cunho pessoal. Contudo, dessa união de duas ou mais vidas, dessa troca de angústias, emerge um conhecimento muito mais significativo do que qualquer outro.

Ao abrirem-se uns aos outros pelo diálogo, ao ouvirem-se mutuamente e na tentativa de entender a necessidade alheia, criam-se parcerias. Nelas, cada professor tende a arriscar-se por atividades mais complexas, assumem para si a responsabilidade por seu desempenho, além de demonstrarem-se atentos às necessidades do outro. Foi assim no caso da coordenadora pedagógica que auxiliou seu professor. O comprometimento entre ambos permitiu-Ihes um trabalho em conjunto, de modo que um sustentasse o outro, conduzindo-os a trabalhos e posturas melhores. Nessa parceria, ambos se desenvolveram.

Outra manifestação da atitude interdisciplinar está no RESPEITO fortalecido pela alteridade. Como a maioria dos professores trabalha junto há alguns anos, todos se conhecem bem de forma que o respeito entre eles predomine. Cada um tem consciência das diferenças que existem dentro do grupo e sabem trabalhar com isso. Dessa forma, existe uma cumplicidade entre o corpo docente percebida por todos, principalmente pelos alunos.

Muitos têm posturas diferentes dentro da escola, porém, nenhum deles é vítima de comentários maldosos por parte de seus colegas. Há sempre a consciência de que adotam modos de trabalhar distintos, que privilegiam certas atitudes em detrimento de outras que a seus colegas podem ser importantes e, mesmo assim, todos conseguem atuar positivamente, encontrando no outro um companheiro, um verdadeiro parceiro. Esse quesito apresenta-se como o de maior importância e o de máximo pesar.

Os professores relacionam-se bem, respeitam-se mutuamente e reconhecem o valor uns dos outros, mas não conseguem transformar esse sentimento em uma 
efetiva atitude interdisciplinar que culmine na elaboração de novos saberes. Talvez, com um pouco mais de consciência dos princípios a que se alude nesse trabalho, essa dificuldade seja sanada. O importante é que o sentimento de pertença que existe dessa positiva relação entre eles permite que o professor sinta-se à vontade para arriscar por novos projetos, por tentar coisas novas, por colocar-se em situações mais complexas, levando-o também ao desenvolvimento.

Para que a atitude interdisciplinar seja realmente parte da escola e do cotidiano docente, o maior empecilho parece ser o DESAPEGO. Abandonar a segurança de uma prática já conhecida, de um conhecimento que lhe acompanha há anos, em troca de uma postura incerta e de um saber ainda a construir não seduz a muitos. O sentimento de insegurança mostra-se mais forte que o desejo pelo novo, o que impede o professor de abandonar os limites conhecidos de sua disciplina.

Sem o desapego, a troca de experiências amparada pela RECIPROCIDADE não acontece. Existe sempre alguém pronto para colaborar, para partilhar seu conhecimento e aceitar tal oferta significa compreender as coisas numa visão maior. A reciprocidade é uma via de mão dupla, ambos oferecem seus saberes, sem disputa, mas com união de modo a aproximarem-se ainda mais da verdade.

Ainda que as dificuldades sejam muitas, mesmo que a atitude interdisciplinar se manifeste em situações pontuais, elas são o RECONHECIMENTO de que já existe na escola a interdisciplinaridade. Porém, é inegável a necessidade de se ampliar sua presença. Ela, que já tem a aceitação dos docentes, precisa de ainda um pouco mais de conhecimento teórico, de modo que a consciência por cada atitude praticada seja forte e persistente, superando qualquer busca por resultados imediatistas.

Em suma, é preciso a ESPERA VIGIADA, que aguarda a transformação das atitudes docentes, porém, não de forma passiva, como quem aguarda uma mudança milagrosa. A elevação da atitude docente em atitude interdisciplinar origina-se na própria atuação docente, cujas escolhas modificam seu modo para consigo mesmo, para com os outros e, desse modo, eleva a condição de todos que atuam na escola.

A atitude interdisciplinar nasce da atuação do professor. As teorias não são suficientes para convencer a todos sobre os benefícios dessa atitude. Sendo assim, os professores envolvidos na pesquisa já deram os primeiros passos para corroborar a interdisciplinaridade dentro da escola e, consequentemente, conduzir a todos pelo desenvolvimento humano, conforme visto nas observações. 


\section{NOTAS}

1. O termo "ser-no-mundo" representa a relação direta entre a pessoa e a realidade em que se encontra. O mundo é tudo o que cerca a pessoa e que a afeta e ou condiciona, mas que ao mesmo tempo é também modificado por ela. Quanto maior consciência da realidade, maior é a capacidade da pessoa em transformar e impor sua identidade ao mundo.

2. Nas obras "Utopia", de Thomas More, e "Cidade do sol", de Tomás Campanella, há uma crítica à sociedade a partir da criação de uma sociedade perfeita, atentas aos anseios e virtudes dos homens. São lugares além da realidade, enfim, inexistentes.

3. Em "Admirável mundo novo", livro de Adouls Huxley, as pessoas negam sua consciência, abandonam o conhecimento da realidade em troca de uma pretensa tranqüilidade e organização, sustentada por uso de drogas que retiram que os tornam simples autômatos.

4. No original: "Pois onde há dois ou três reunidos em meu nome, aí estou eu, no meio deles" - Mateus, capítulo 18, versículo 20.

5. A maiêutica socrática representa a atitude do filósofo Sócrates em auxiliar as pessoas a deixar sair, a dar a luz, aos conhecimentos que existem em cada pessoa. O próprio pensador utiliza-se desse termo ao comparar sua atividade ao de sua mãe, uma verdadeira parteira. Ele dizia que ela auxiliava os bebês a nascer, ele, as ideias.

6. O Oráculo de Delfos era um templo religioso dedicado ao deus Apolo. Em sua entrada havia uma inscrição que dizia "conhece-te a ti mesmo" assumida por Sócrates.

7. A virtude para Aristóteles possui dois caminhos: o intelectual e o moral. 0 primeiro é o resultado da aprendizagem, da educação e se amplia de acordo com o tempo e pelo acumulo de experiência; o segundo é composto de atitudes que se repetem no cotidiano. O bem (justiça, honestidade...) somente 
se efetiva e se concretiza no agir, no esforço em incorporar na atitude diária aquilo que é definido por correto.

8. Kairós, do grego kaıpós que significa "o momento certo" ou "oportuno".

9. Cronos refere-se ao tempo cronológico, ou seqüencial, o tempo que se pode medir (horas, dias, meses, anos).

10.O termo "Fenomenologia" designa o estudo do fenômeno tal qual este se apresenta à nossa experiência. Consequentemente o método fenomenológico tenciona uma volta às coisas mesmas, isto é, observar e descrever com exatidão os fenômenos, tal como ele se manifesta ao sujeito.

11.PCN = São diretrizes voltadas para a estruturação e reestruturação dos currículos escolares de todo o Brasil - obrigatórias para a rede pública e opcionais para as instituições privadas.

12.REDEFOR (rede são Paulo de formação docente) é um programa criado pela secretaria da Educação do Estado de São Paulo em conjunto com as universidades públicas paulistas: USP, UNICAMP, UNESP. Seu objetivo é prover cursos de especialização (pós-graduação) aos docentes da rede pública paulista na modalidade semipresencial, ou seja, oferecidos a distância e com encontros presenciais no decorrer do curso.

13.Bolsa mestrado / doutorado: Iniciativa que tem por objetivo estimular a melhora da qualificação de docentes, supervisores e diretores da rede estadual oferecendo a eles auxilio financeiro e diminuição da jornada de trabalho.

14. HTPC = Sigla para Hora de trabalho pedagógico coletivo. Nesse tempo os professores se reúnem para debater sobre assuntos pedagógicos, tratam das estratégias para o ensino e também para dar continuidade a sua própria formação. Seria um excelente momento para a troca de ideias que faz nascer a interdisciplinaridade. 


\section{REFERÊNCIAS}

ABBAGNANO, N. Dicionário de Filosofia. São Paulo: Martins Fontes, 2007.

ABRAMOVAY, M.; CASTRO, M. G. Ensino médio: múltiplas vozes. Brasília: UNESCO, MEC, 2003.

ALARCÃO, I. Do olhar supervisivo ao olhar sobre a supervisão. In: ANGEL, M. (Org.) Supervisão pedagógica: princípios e práticas. Campinas: Papirus, 2001.

ALVARENGA, A. T. de; PHILIPPI JR, A.; SOMMERMAN, A.; ALVARES, A. M. de S.; FERNANDES, $V$. Histórico, fundamentos filosóficos e teórico-metodológicos da interdisciplinaridade. In: PHILIPPI JR, A.; SILVA NETO, A. J. Interdisciplinaridae em ciência, tecnologia \& Inovação. São Paulo, Manole, 2011.

ALVEZ, C. Humildade. In: FAZENDA, I. C. A. (Org.). Dicionário em construção: interdisciplinaridade. São Paulo: Cortez, 2002.

ARANHA, M. L. de A., MARTINS, M. H. P. Temas de Filosofia. São Paulo: Moderna, 1998.

ARISTÓTELES. ÉTICA A NICÔMACO; POÉTICA. Col.: Os Pensadores. 4. ed. São Paulo: Nova Cultural, 1987.

BICUDO, M. A. V. Fenomenologia: confrontos e avanços. São Paulo: Cortez, 2000.

BORNHEIM, G. Introdução ao filosofar: o pensamento filosófico em bases existenciais. 3. ed. São Paulo: Globo, 2009.

BRONFENBRENNER, U. Ecological models of human development. International Encyclopedia of Education. 2. ed. v.3. Oxford: Elsevier, 1994. Disponível em: <www.psy.cmu.edu/ siegler/35bronfebrenner94.pdf>. Acesso em: 21 set. 2010.

A ecologia do desenvolvimento humano: experimentos naturais e planejados. Porto Alegre: Artes Médicas, 1996.

. Bioecologia do desenvolvimento humano: tornando os seres humanos mais humanos. Porto Alegre: ArtMed, 2011.

BRASIL. Lei n. 9.394/96. Lei de Diretrizes e Bases da Educação. Rio de Janeiro: DP\&A, 1999. Disponível em: <www.senado.gov.br>. Acesso em: 27 abr. 2011.

. Ministério da Educação. Conselho Nacional de Educação. Resolução CEB/ CNE n. 03/98 - Diretrizes Curriculares Nacionais para o Ensino Médio, 1998. Disponível em: <www.senado.gov.br>. Acesso em: 27 abr. 2011.

. Ministério da Educação. Conselho Nacional de Educação. Parecer CEB/ CNE n. 11/2009 - Proposta de experiência curricular inovadora do Ensino Médio, 2009. Disponível em: <www.senado.gov.br>. Acesso em: 27 abr. 2011. 
BRASIL. Ministério da Educação. Conselho Nacional de Educação. Parecer CEB/ CNE n. 15/98 - Diretrizes Curriculares Nacionais para o Ensino Médio, 1998. Disponível em: <www.senado.gov.br>. Acesso em: 27 abr. 2011.

. Ministério da Educação. Resolução no 4, de 13 de julho de 2010. Define Diretrizes Curriculares Nacionais Gerais para a Educação Básica. Brasília: Conselho Nacional de Educação / Câmara de Educação Básica, 2010. Disponível em: <www.senado.gov.br>. Acesso em: 27 abr. 2011.

. Ministério da Educação. Conselho Nacional de Educação. Resolução CEB/ CNE n. 07/2010 - Diretrizes Curriculares Nacionais Gerais para a Educação Básica, 2010. Disponível em: <www.senado.gov.br>. Acesso em: 27 abr. 2011.

BRUNDANI, A. R.; SASSAKI, A. H. Formação de estratégia na visão da teoria institucional: críticas ao modelo. ETIC Encontro de Iniciação Científica. Presidente Prudente, v.3, n.3. 2007. Disponível em: $<$ http://intertemas.unitoledo.br/revista>. Acesso em: 01 jan. 2011.

BUENO, E. R. de A. Fenomenologia: a volta às coisas mesmas. In: PEIXOTO, A. J. (Org). Interações entre fenomenologia e educação. São Paulo: Alínea, 2003.

CARROLL, L. Alice no país das maravilhas. Porto Alegre: L\&PM, 1998.

CASCINO, F. Espera. In: FAZENDA, I. C. A. (Org.). Dicionário em construção: interdisciplinaridade. São Paulo: Cortez, 2002.

CECONELLO, A. M.; KOLLER, S. H. Inserção ecológica na comunidade: uma proposta metodológica para o estudo de famílias em situação de risco. Psicologia: reflexão e crítica. Porto Alegre, v.16, n.3. 2003. Disponível em: <www.scielo.br>. Acesso em 01 jul. 2011.

CHAGAS, J. F.; ASPESI, C. de C.; FLEITH D. de S. A relação entre criatividade e desenvolvimento humano: uma visão sistêmica. In: DESSEN, M. A.; COSTA JUNIOR, A. L. (Org.). A ciência do desenvolvimento humano: tendências atuais e perspectivas futuras. Porto Alegre: Artmed, 2005.

CHAUÍ, M. Convite à Filosofia. São Paulo: Ática, 2004.

CHIAVENATO, I. Introdução à teoria geral da administração: uma visão abrangente da moderna administração das organizações. Rio de Janeiro: Elsevier, 2003.

COIMBRA, J. de Á. A. Considerações sobre a interdisciplinaridade. In: Interdisciplinaridade em Ciências Ambientais. São Paulo: Signus, 2000.

DESCARTES, R. O discurso do método; As paixões da alma. Col.: Os Pensadores. 4. ed. São Paulo: Nova Cultural, 1987

DESSEN, M. A.; COSTA JUNIOR, A. L. (Org.). A ciência do desenvolvimento humano: tendências atuais e perspectivas futuras. Porto Alegre: Artmed, 2005. 
DESSEN, M. A.; GUEDEA, M. T. D. A ciência do desenvolvimento humano: ajustando o foco de análise. Paideia. Ribeirão Preto, v.15, n. 30. Jan./abr. 2005. Disponível em: <www.scielo.br/paideia> . Acesso em: 18 ago. 2010.

DESSEN, M. A.; POLONIA, A. da C. A família e a escola como contextos de desenvolvimento humano. Paideia. Ribeirão Preto, v.17, n. 36. Jan./abr. 2007. Disponível em: <www.scielo.br/paideia>. Acesso em: 18 ago. 2010.

DINIZ, E; KOLLER, S. H. O afeto como um processo de desenvolvimento ecológico. Educar. Curituba, n.36. 2010. Disponível em: <www.scielo.br/pdf/er/n36/a06n36.pdf>. Acesso em 21 set. 2010.

FAZENDA, I. C. A. Interdisciplinaridade: um projeto em parceria. São Paulo: Loyola, 1991. 2000. Interdisciplinaridade: história, teoria e pesquisa. 6 ed. Campinas: Papirus, Construindo aspectos teórico-metodológicos da pesquisa sobre interdisciplinaridade. In: FAZENDA, I. C. A. (Org.). Dicionário em construção: interdisciplinaridade. São Paulo: Cortez, 2002.

2003.

Interdisciplinaridade: Qual o sentido? 11 ed. Campinas, SP: Papirus,

. A formação do professor pesquisador - 30 anos de pesquisa. Revista ECurriculum, PUCSP, São Paulo, v.1, n.1, 2005. Disponível em: $<$ www.pucsp.br/ecurriculum>. Acesso em: 5 ago. 2010.

. Interdisciplinaridade e Transdisciplinaridade na formação de professores. Revista Brasileira de Docência, Ensino e Pesquisa em Administração, FACEC, Goiás, v.1, n. 1, maio. 2009a. Disponível em: <http://www.facec.edu.br/seer/index.php>. Acesso em: 5 ago. 2010.

. Formação de professores: Dimensão interdisciplinar. Revista Brasileira de Formação de Professores, FACEC, Goiás, v.1, n. 1, maio. 2009b. Disponível em: <http://www.facec.edu.br/seer/index.php>. Acesso em: 5 ago. 2010.

FIERRO, A. O desenvolvimento da personalidade na idade adulta e na velhice. In: COLL, C.; MARCHESI, A.; PALACIOS, J. (Org.). Desenvolvimento psicológico e educação. 2. ed.Porto Alegre: Artmed, 2004.

FLAVELL, J. H.; MILLER, P. H.; MILLER, S. A. Desenvolvimento cognitivo. 3. ed. Porto Alegre: Artes Médicas, 1999.

FURLANETTO, E. C. Fronteira. In: FAZENDA, I. C. A. (Org.). Dicionário em construção: interdisciplinaridade. São Paulo: Cortez, 2002. 
GIACON, B. D. M. Coerência. In: FAZENDA, I. C. A. (Org.). Dicionário em construção: interdisciplinaridade. São Paulo: Cortez, 2002.

GOETHE, J. W. V. Fausto. São Paulo: Martin Claret, 2009.

GUSDORF, G. Professores para que? São Paulo: Martins Fontes, 1987.

HARTMANN, A. M. Desafios e possibilidades da Interdisciplinaridade no Ensino Médio. Brasília. Universidade de Brasília: Faculdade de Educação, Jan. 2007.

HERÁCLITO. Os filósofos pré-socráticos. São Paulo: Cultrix, 1993.

HESSEN, J. Teoria do conhecimento. São Paulo: Martins Fontes, 2000.

JAPIASSU, H; MARCONDES, D. Dicionário básico de filosofia. 2 ed. Rio de Janeiro: Zahar, 2006.

JUSTINA, R. D. Parceria. In: FAZENDA, I. C. A. (Org.). Dicionário em construção: interdisciplinaridade. São Paulo: Cortez, 2002.

LAKATOS, E. M.; MARCONI, M. de A. Fundamentos de metodologia científica. 2 ed. São Paulo: Atlas, 1990.

LANE, S. T. M. O que é psicologia social. São Paulo: Brasiliense, 1981.

LENOIR, Y. Três interpretações da perspectiva interdisciplinar em educação em função de três tradições culturais distintas. Revista E-Curriculum, PUCSP, São Paulo, v.1, n. 1, 2005-2006. Disponível em: <http://www.pucsp.br/ecurriculum>. Acesso em: 5 ago. 2010.

LENOIR, Y. A importância da interdisciplinaridade na formação de professores do ensino fundamental. Caderno de Pesquisa, FCC, São Paulo, n. 102, 2007.

Disponível em: <www.fcc.org.br>. Acesso em: 5 ago. 2010.

LENOIR, Y.; HASNI, A. La interdisciplinaridad: por um matrimonio abierto de La razon, de La mano y del corazón. Revista Ibero-Americana de Educación. n.35. 2004. Disponível em: < http://www.rieoei.org/rie35a09.htm>. Acesso em 01 jul. 2011.

LUZZI, D. A.; PHILIPPI JR, A. Interdisciplinaridade, pedagogia e didática da complexidade na formação superior. In: PHILIPPI JR, A.; SILVA NETO, A. J. Interdisciplinaridade em ciência, tecnologia \& inovação. São Paulo: Manole, 2011.

MADUREIRA, A. F. do A.; BRANCO, A. M. C. U. de. Construindo com o outro: uma perspectiva sociocultural construtivista do desenvolvimento humano. In: DESSEN, M. A.; COSTA JUNIOR, A. L. (Org.). A ciência do desenvolvimento humano: tendências atuais e perspectivas futuras. Porto Alegre: Artmed, 2005.

MAQUIAVEL, N. O príncipe. São Paulo: Martin Claret, 2000. 
MAXIMIANO, A. C. A. Introdução à administração. São Paulo: Atlas, 2000.

MENÉNDEZ, N. Z. Parceria. In: FAZENDA, I. C. A. (Org.). Dicionário em construção: interdisciplinaridade. São Paulo: Cortez, 2002.

MORGAN, G. Imagens da organização. São Paulo: Atlas, 1996.

MOSCOVICI, F. Desenvolvimento Interpessoal. Rio de Janeiro: José Olympio, 1998.

NEIVA, E. R.; PAZ, M. das G. T. da. Percepção de mudança organizacional: um estudo em uma organização pública brasileira. Revista de Administração Contemporânea. Curitiba. V.11, n.1. Jan./Mar. 2007. Disponível em: <www.scielo.br/scielo $>$. Acesso em: 11 jan. 2011.

NICOLESCU, B. Um novo tipo de Conhecimento: Transdisciplinaridade. I Encontro Catalisador do CETRANS: Escola do Futuro. USP. Itatiba, S.P. abril. 1999.

Disponível em: < www.ufrrj.br/leptrans/arquivos/conhecimento.pdf> Acesso em: 21 set. 2010.

OLIVEIRA, E. T. de; SCORALICK, K. Emmanuel Lévinas: ética e alteridade. In: Discutindo filosofia, n. 4, ano 1. São Paulo: Escala Educacional, 2008.

POLETTO, M.; KOLLER, S. H. Contextos ecológicos: promotores de resiliência, fatores de risco e de proteção. Estudos de psicologia. Campinas. v.25. n.3. jul / set. 2008. Disponível em: <www.scielo.br/scielo>. Acesso em: 11 jan. 2011.

POLONIA, A. da C.; DESSEN, M. A.; SILVA, N. L. P. O modelo bioecológico de Bronfenbrenner: contribuições para o desenvolvimento humano. In: DESSEN, M. A.; COSTA JUNIOR, A. L. (Org.). A ciência do desenvolvimento humano: tendências atuais e perspectivas futuras. Porto Alegre: Artmed, 2005.

POLONIA, A. da C.; SENNA, S. R. C. M. A ciência do desenvolvimento humano e suas interfaces com a educação. In: DESSEN, M. A.; COSTA JUNIOR, A. L. (Org.). A ciência do desenvolvimento humano: tendências atuais e perspectivas futuras. Porto Alegre: Artmed, 2005.

POMBO, O. A interdisciplinaridade como problema epistemológico e exigência curricular. Revista Inovação. CFCUL. v.6, n.2, 1993. Disponível em: $<$ http://cfcul.fc.ul.pt/textos $>$. Acesso em: 21 set. 2010.

POMBO, O. Interdisciplinaridade e integração dos saberes. Liinc em Revista. UFRJ. v.1, n.1, 2005. Disponível em: <www.ibict.br/liinc>. Acesso em: 21 set. 2010.

POMBO, O. Epistemologia da Interdisciplinaridade. Ideação - Revista do centro de Educação e letras da Unioeste - Campus de Foz do Iguaçu. V.10, n.01, 2008. Disponível em: < http://www.humanismolatino.online.pt/v1/pdf/C002_11.pdf> Acesso em: 21 set. 2010. 
PRATI, L. E.; COUTO, M. C. P. de P.; MOURA, A.; POLETTO, M.; KOLLER, S. H. Revisando a inserção ecológica: uma proposta de sistematização. Psicologia:

Reflexão e crítica. Porto Alegre. 2008. Disponível em <www.scielo.br/prc $>$ Acesso em: 21 set. 2010.

QUELUZ, A. G. Tempo. In: FAZENDA, I. C. A. (Org.). Dicionário em construção: interdisciplinaridade. São Paulo: Cortez, 2002.

RAMOS, G. T. Mudança. In: FAZENDA, I. C. A. (Org.). Dicionário em construção: interdisciplinaridade. São Paulo: Cortez, 2002.

RANGHETTI, D. S. Afetividade. In: FAZENDA, I. C. A. (Org.). Dicionário em construção: interdisciplinaridade. São Paulo: Cortez, 2002.

RAYNAUT, C. Interdisciplinaridade: mundo contemporâneo, complexidade e desafios à produção e à aplicação de conhecimentos. In: PHILIPPI JR, A.; SILVA NETO, A. J. Interdisciplinaridae em ciência, tecnologia \& Inovação. São Paulo, Manole, 2011.

RICOEUR, P. Percurso do reconhecimento. São Paulo: Loyola, 2006.

SAINT-EXUPÉRY, A. de. Terra dos Homens. 23 ed. Rio de Janeiro: José Olympio. 1981.

SALVADOR, C. C. Psicologia da educação. Porto Alegre: Artmed, 1999.

SANTOMÉ, Jurjo Torres. Globalização e interdisciplinaridade. Porto Alegre: Artmed, 1998.

SIFUENTES, T. R.; DESSEN, M. A.; OLIVEIRA, M.C.S.L. de. Desenvolvimento humano: desafios para a compreensão das trajetórias probabilísticas.

Psicologia: teoria e pesquisa. Brasília, v.23, n. 4. Out./Dez. 2007. Disponível em: $<$ http://www.scielo.br/paideia >. Acesso em: 18 ago. 2010.

SILVA, E. L. da; MENEZES, E. M. Metodologia da pesquisa e elaboração de dissertação. 4 ed. Florianópolis: UFSC, 2005.

SILVEIRA, V. N. S. Racionalidade e Organização: as múltiplas faces do enigma. Revista de Administração Contemporânea. Curitiba. V.12, n.4. Out./Dez. 2008. Disponível em <http://www.scielo.br/scielo> . Acesso em: 11 Jan. 2011.

SOUZA, L. C. P. de. Ação. In: FAZENDA, I. C. A. (Org.). Dicionário em construção: interdisciplinaridade. São Paulo: Cortez, 2002.

SOMMERMAN, A. A Inter e a Transdisciplinaridade. X Seminário Internacional de Educação: Interdisciplinaridade como forma de inclusão numa educação mundial. Cachoeira do Sul. RS. Junho. 2005. Disponível em: <http://www.ouviroevento.pro.br/index/comp e trans textos.htm\#Sommerman> Acesso em: 21 set. 2010. 
SUÁREZ, D. H. A documentação narrativa de experiências pedagógicas como estratégia de pesquisa-ação-formação de docentes. In: PASSEGGI, M. da. C; BARBOSA, T. M. N. Narrativas de formação e saberes biográficos. Natal. EDUFRN; São Paulo: Paulus, 2008.

TAINO, A. M. R. O movimento do percurso de reconhecimento na formação interdisciplinar. In: Congresso Internacional de Pesquisa (auto) biográfica: formação, territórios e saberes, 3., 2008, Natal. ANAIS... Natal: UFRN, 2008. 1 CD-ROM.

TERENCE, A. C. F.; ESCRIVÃO FILHO, E. Abordagem quantitativa, qualitativa e a utilização da pesquisa-ação nos estudos organizacionais. XXVI ENEGEP. Fortaleza, Outubro. 2006.

THIESEN, J. S. A interdisciplinaridade como um movimento articulador no processo ensino-aprendizagem. Revista Brasileira de Educação. São Paulo, v.13, n.19, set./dez.2008. Disponível em:

$<$ http://redalyc.uaemex.mx/src/inicio/ArtPdfRed.jsp?iCve=27503910> Acesso em: 21 set. 2010.

TRAGTENBERG, M. Sobre educação, política e sindicalismo. São Paulo: UNESP, 2004.

UNAMUNO, M. de. Do sentimento trágico da vida. Porto: Educação Nacional, 1953.

UNESCO. Carta da transdiciplinaridade. Primeiro Congresso Mundial da Transdisciplinaridade, Convento da Arrábida, Portugal. Nov. 1994. Disponível em: <http://www.universidadedoespirito.org >. Acesso em: 21 set. 2010.

UNESCO. Protótipos curriculares de Ensino Médio e Ensino Médio integrado: resumo executivo. Série Debates. Brasília: UNESCO, 2011.

VIANNA, H. M. Pesquisa em educação: a observação. Série pesquisa em ação, v.5. Brasília: Plano Editora, 2003.

ZABALA, A. Enfoque globalizador e pensamento complexo. Porto Alegre: Artmed, 2002. 


\section{APÊNDICE B - TERMO DE CONSENTIMENTO LIVRE E ESCLARECIDO}

Você está sendo convidado (a) para participar, como voluntário, em uma pesquisa. Após ser esclarecido (a) sobre as informações a seguir, no caso de aceitar fazer parte do estudo, assine ao final deste documento, que está em duas vias. Uma delas é sua e a outra é do pesquisador responsável. Em caso de recusa você não será penalizado (a) de forma alguma.

\section{INFORMAÇÕES SOBRE A PESQUISA}

Título do Projeto: A atitude interdisciplinar docente como propulsora do desenvolvimento humano no ensino médio

Pesquisador Responsável: Daniel de Carvalho Costa

Telefone para contato (inclusive ligações a cobrar): (12) 91602553

Pesquisadores participantes: Prof $^{a}$ Dra. Maria Aparecida Campos Diniz de Castro e Prof $^{a}$. Dra. Ana Maria dos Reis Taino

Telefones para contato: 1 (12) 91602553

Esta pesquisa está sendo realizada por Daniel Carvalho Costa, aluno do Programa de Pós-Graduação em Desenvolvimento Humano (PPGDH) da Universidade de Taubaté. Seu objetivo é analisar há ação interdisciplinar docente enquanto promotora do desenvolvimento humano no espaço escolar do ensino médio. Os resultados dessa pesquisa serão utilizados apenas para fins acadêmicos.

Seguindo os preceitos éticos, informamos que sua participação será absolutamente sigilosa, não constando seu nome ou qualquer outro dado referente à sua pessoa que possa identificá-lo no relatório final ou em qualquer publicação posterior sobre esta pesquisa. Pela natureza da pesquisa, sua participação não acarretará em qualquer dano a sua pessoa.

Você tem a total liberdade para recusar sua participação, assim como solicitar a exclusão de seus dados, retirando seu consentimento sem qualquer penalidade ou prejuízo, quando assim o desejar.

A qualquer momento da pesquisa o entrevistado que se sentir prejudicado poderá contatar o pesquisador responsável, sua orientadora ou o Comitê de Ética na Pesquisa da Universidade de Taubaté (PRPPG-Pró-reitoria de Pesquisa e Pós-graduação - Comitê de 
Ética em Pesquisa - Rua Visconde do Rio Branco, 210 Centro Taubaté-SP 12020-040 Tel.: (12) 3625.4143 - 3635.1233 Fax: (12) 3632.2947 - cepunitau@unitau.br).

Agradeço sua participação, enfatizando que a mesma em muito contribui para a formação e para a construção de um conhecimento atual nesta área.

Taubaté, Janeiro de 2011

\section{Daniel de Carvalho Costa \\ Pesquisador}

\section{Orientadora: Profa. Dra. Maria Aparecida Campos Diniz Castro Co-orientadora: Profa. Dra. Ana Maria dos Reis Taino}

\section{CONSENTIMENTO DA PARTICIPAÇÃO DA PESSOA COMO SUJEITO}

Tendo ciência das informações contidas neste Termo de Consentimento Livre e Esclarecido, eu , portador do $\mathrm{RG} \mathrm{n}^{0}$ autorizo a utilização, nesta pesquisa, dos dados por mim fornecidos. 


\section{APÊNDICE C - MEMORIAL}

\section{Daniel de Carvalho Costa}

Estamos habituados a contemplar o amanhã, a enxergar no horizonte nossos projetos e sonhos de modo que com o espírito habitando o futuro, cabe aos nossos esforços buscar realizar no hoje as ações que elevem tais ilusões à condição de realidade. Contudo, por mais que nossos projetos indiquem a direção de nossas escolhas, eles pouco podem dizer de nossa identidade já que o futuro tem a fragilidade da mudança, a inconsistência do não realizado, ou seja, não apresenta garantias existenciais.

Por isso, quando buscamos entender quem verdadeiramente somos, é ao passado que reportamos. São nossas pretéritas ações que revelam nossas características, exteriorizando crenças e valores diante de cada situação. O que fizemos demonstra os paradoxos que formam cada pessoa, assim, ao longo dos dias que se foram vislumbramos covardia e coragem, derrotas e vitórias, maldades e bondades que narradas no conjunto da obra denominada vida, garantem significado ao nosso presente e dão sentido ao futuro.

Olhar o passado é perceber o quanto pudemos realizar e com imensa satisfação reconhecemos que não fizemos nada sozinhos. Por mais que as escolhas e a vivência da liberdade seja analisada sempre sob um foco individual, é inegável a participação dos outros em nossos dias. Para contar minhas memórias impõem-se a necessidade de mostrar que houve sempre pessoas especiais que se misturaram à minha história e me auxiliaram a construí-la.

Sendo assim, um memorial é também uma história coletiva, de um personagem central cercado por outros igualmente principais. Estes que se influenciam mutuamente só diferem entre si por um deles ser dono da narrativa em questão, tornando-se centro da atenção. É dentro desse contexto que posso, enquanto relato minha história, destacar nela questões sobre o desenvolvimento.

Abordar esse assunto dentro de um memorial me parece a expressão de uma inerente característica desse documento, pois, a história da nossa vivencia é formada por desafios que nos conduzem à situações cada vez mais complexas e cuja superação nos coloca em um patamar melhor, gera em nós transformações positivas identificadas como desenvolvimento humano. 
Descrever e ressaltar esse processo significa colocar nossa própria vida como matriz e exemplo de todo conceito aprendido nesse curso de mestrado. Relembrar as passagens que conduziram minha formação significa narrar minhas ações individuais, expor as decisões que tomei e contar o trato com as consequências que delas provém, sejam negativas ou positivas.

Porém, hoje sei que narrar minhas passagens exige ir além da simples exposição de minhas escolhas. É preciso relatar a participação das pessoas que estiveram ao meu lado e as coisas que fizemos juntos. Muitas ações realizei individualmente, mas, estas sempre têm um caráter menor diante da maravilha dos momentos partilhados. É como se cada nova vida que se aproximasse da minha elevasse os sentimentos à qualidade de inesquecíveis.

Talvez, esta introdução cause uma percepção errada de minha história. Existem, sim, momentos em minha vida que considero grandiosos. Mas, em grande parte desta narrativa o que se vê é o singelo cotidiano. O tempo passando sem o agito das baladas, sem o status das compras ou das viagens. Ao contrário, muito de meu tempo se passou sentado numa praça, em frente a minha casa. Mas, na conversa com os amigos, na roda de violão, encontrávamos sempre a felicidade. Falarei agora, um pouco mais de minha trajetória, e isso significa que relatarei como as relações humanas me conduziram até o que sou hoje.

Grande parte de minha vida foi vivida em Pindamonhangaba, sempre nos bairros longe do centro, pertencente a uma família de pais trabalhadores - pai, industrial e mãe, doméstica -, e com um único irmão, mais novo. A vida sempre nos deu o necessário, o restante não faltava. Em casa, os valores religiosos eram partilhados, e este exemplo vai ser fundamental para algumas decisões futuras. Outro fator primordial estava ligado ao estudo.

Todo esforço era feito para que nada faltasse com relação a isso. Lembro-me que desde muito cedo compreendi a situação de luta em que vivíamos, do esforço em pagar as contas, e por isso, era para mim muito difícil pedir algo a mais. Quando alguns cursos nos eram oferecidos na escola (às vezes informática, outras a língua inglesa) não tinha coragem de expor a meus pais o interesse que tais cursos despertavam em mim. Pelo menos não o fazia de maneira direta. Minha estratégia consistia em deixar a mostra a propaganda do curso, de modo que ao vê-lo meus pais se conscientizassem de meus desejos. E a partir disso analisavam a possibilidade de realizá-lo. Alguns pude fazer, outros não. 
Desde esse tempo, a escola pública foi meu ambiente. E neste contexto de socialização fatores decisivos ocorreram. Ao entrar nesse ambiente carregava comigo uma bagagem bem modelada de valores preparada pela convivência familiar e que seria colocada a prova na presença desses outros diferentes e estranhos a mim. Mas o que se deu foi o encontro com pessoas que possibilitaram uma troca de ideias e valores capazes de fazer amadurecer a todos que de nós se aproximavam. Essa amizade, construída em tão tenra idade, se arrastou pelos anos. Permitiu que o Ensino Fundamental fosse lembrado com extremo carinho e se estendeu até o Ensino Médio.

Nesse novo período escolar, há uma mudança de ambiente - saio de uma escola de bairro e vou estudar no centro da cidade - e um foco no ensino - ensino técnico em mecânica. Concomitantemente os trabalhos sociais começam a aparecer. Junto com os amigos que me acompanhavam desde o ensino fundamental formamos um grupo de jovens com o intuito de apreender, discutir e agir sobre os desafios que se apresentavam a toda a juventude. Este grupo se consolidou por uma amizade e um estilo de valores que influenciaram as escolhas seguintes.

Com o término do ensino médio veio o serviço militar e após, o trabalho nas indústrias. O exercício da função técnica não foi o esperado. $O$ trabalho trouxe uma série de questionamentos acerca do objetivo de estar ali e exercer aquela função. Seria apenas pelo salário? Não haveria como encontrar um caminho que me oferecesse também a "realização"? A resposta a esta pergunta me conduziu a uma mudança total de percurso, conduzindo-me ao seminário.

$\mathrm{Na}$ vida seminarística, há um afastamento das coisas que sempre considerei importante. Minha casa e meus pais, assim como meu irmão e amigos, ficaram mais distantes. Estava em outra cidade e as oportunidades de vê-los era mais restrita. Contudo, tudo parecia valer a pena. Os valores que tanto me acompanharam ganham corpo. O reconhecimento do outro, a opção pela entrega, a vivência da alteridade, a busca constante pelo conhecimento que seria colocado à disposição de todos, tudo isso se faz presente nos quatro anos em que habito a instituição religiosa.

Esses anos possibilitam conhecer a realidade dessa escolha. Ao estar nas paróquias, com o povo, é possível reconhecer os desafios que deveria assumir no restante da vida. Mais do que isso, os anos que ali vivi me ofereceram um 
conhecimento que nenhuma outra instituição ainda havia me oferecido. O estar no seminário, a ida às paróquias nos finais de semana me colocavam diante do desconhecido, eu me via em lugares estranhos, com pessoas com quem não tinha nenhuma afinidade. Essa dificuldade mostrou um lado social e sociável em mim que me fez amadurecer profundamente. A disposição e a abertura ao outro se intensificaram, mas não era ainda isso que desejava.

Volto para casa, havia ficado quatro anos no seminário. Lá dentro havia cursado três anos do curso de Filosofia. Busquei aulas como eventual e com isso consegui pagar o último ano da faculdade. Neste mesmo ano o governo do Estado abre novo concurso para professor. Esse é o ano de 2005 e o resultado foi a aprovação no concurso. No ano seguinte já sou professor efetivo do Estado. A situação era boa, mas permanecer nisso me incomodava. Já surgia em mim o desejo da continuidade dos estudos. Mas adiado momentaneamente quando, em novo concurso, consigo novamente ser aprovado e no acúmulo de cargo os intensos horários de trabalho consomem grande parte da minha semana. Foi preciso esperar mais um pouco para me aventurar pelo processo seletivo de um mestrado.

Já havia tentado participar da pós-graduação em Filosofia pela mesma Unitau, mas por falta de coro o curso não foi realizado. Quando surgiu a oportunidade do mestrado em Desenvolvimento Humano reconheci a oportunidade que esperava. Sem pensar muito nas consequências, trilhei os passos que me permitiriam ingressar nesse grupo.

Ingressar no mestrado representava o esforço em concretizar dois objetivos. O primeiro, diz respeito à continuidade do estudo e do aprendizado. Acredito seriamente que buscar conhecimento seja árduo. Existe sempre o prazer pela conquista, a satisfação pela compreensão do conteúdo ou pela descoberta de respostas, porém, o caminho que conduz à felicidade é sempre custoso. E mesmo com tanta dificuldade, trilhá-lo é necessário. Pois, se com tanto esforço conquistamos importantes conhecimentos, a descontinuidade desta busca fortalece o esquecimento permitindo que tudo aquilo que fora conquistado desaparecesse. Quando paramos, além de não progredirmos na busca pela verdade, deixamos escapar tudo o que obtivemos. Tornamo-nos obsoletos. E isso ecoa em meu interior como algo inaceitável.

O segundo, ter a possibilidade de avançar na carreira profissional. Conquistei em pouco tempo um espaço importante dentro do meu trabalho. Muitos ambicionam 
um cargo no estado, eu, em três anos, havia obtido dois. Mas, se olharmos o Estado e sua hierarquia, eu havia conquistado tudo aquilo que ele poderia me oferecer. Os desafios que me restavam ligavam-se ao acúmulo de cursos rápidos que me dariam aumento salarial. Eu sempre almejei algo a mais. Queria, e quero experiências diferentes e maiores, ou seja, desejo também as aulas e discussões da universidade. E este projeto está ligado diretamente ao retorno à academia.

Mais do que com o pré-projeto solicitado no período de avaliações e entrevistas do processo seletivo, foi com esses objetivos que me apresentei. $E$ acredito que ele tenha sido fator primordial para meu ingresso. Em cada encontro, nossos futuros professores deixavam claro os obstáculos que um curso como esse impõe aos alunos. Por isso, maior necessidade se fazia da vontade e da perseverança do que dos conhecimentos prévios a respeito dos conceitos do curso. Estes poderiam sempre ser adquiridos bastando as tais qualidades.

Fui aceito. Quando conheci meus companheiros de curso senti-me honrado por estar ao lado deles, ao mesmo tempo, senti uma pressão e um enorme desconforto vindo dessa mesma companhia. Assim o era porque todos os demais dezenove integrantes do curso de mestrado tinham experiências de pesquisa, no mínimo haviam realizado cursos de pós-graduação, enquanto eu ousava um salto direto para o mestrado.

Os primeiros encontros aumentaram este desconforto. A busca pela interdisciplinaridade proposta pelo curso parecia uma utopia diante da disputa disciplinar colocada por cada integrante do grupo. A cada discussão parecia-me que não buscávamos uma compreensão mútua ou mesmo uma verdade maior que englobasse todos os conhecimentos que trazíamos. Não havia naquele momento, entre nós, cooperação. Disputávamos espaço, empunhando as armas obtidas pelos conhecimentos disciplinares que carregávamos. Não tínhamos ainda o preparo de oferecer o que sabíamos como colaboração, tínhamos, sim, a vaidade de impor nossa visão.

Foi o tempo e o difícil reconhecimento de que sozinhos não alcançaríamos os objetivos que caracterizam nosso curso que permitiu nossa mudança. Também as dificuldades em compreender novos conceitos, em cumprir desgastantes prazos, fizeram desses indivíduos um verdadeiro grupo. O apoio que cada um ofereceu ao outro, o auxílio nas dificuldades produziram a coesão necessária para que determinados aspectos positivos ocorressem. 
Paulatinamente, ao abandonarmos nosso individualismo e entendermos e valorizarmos a presença do outro foi possível vivenciar muito daquilo que estávamos estudando e muito daquilo que ainda estudaríamos. Ao construirmos as parcerias, o grupo enfim encontrou o caminho para seu desenvolvimento. Numa troca mútua, cada um se desenvolvia individualmente e isso impunha o desenvolvimento do grupo. Arrisco-me a dizer que o oposto também ocorria, enquanto amadurecíamos coletivamente, isso nos conduzia a patamares individuais sempre maiores e melhores.

Foi com esse espírito que pude superar os obstáculos que se apresentavam. Passado o momento de estranhamento em que passamos de desconhecidos a parceiros. O próximo momento de crise estava na elaboração dos projetos de pesquisa. Quando cheguei ali, ofereci um projeto que estava sobre meus domínios, mesmo sem estar na academia continuei a estudar, a ler, e o fruto desse esforço estava representado numa proposta baseada no pensamento de Hannah Arendt e sua concepção a respeito da condição humana.

Foi extremamente conflituoso perceber que minha proposta inicial ia a cada momento se desfazendo. A cada novo conceito adotado nas aulas, o que havia imaginado ia perdendo força. Foi preciso juntar toda humildade que havia em mim para reconhecer que aquilo que trouxera como projeto não se enquadrava na proposta do curso. Mais do que isso, que minha insistência em discutir Filosofia estava presa à fidelidade disciplinar que propusemos quebrar. Creio que este foi meu maior e decisivo momento dentro do curso. Abandonei minha proposta para adotar outra mais condizente com nossa realidade. E escolhi tudo o que me era proposto. Resolvi falar sobre interdisciplinaridade, adotei o auxílio de Bronfenbrenner e sua Teoria do Desenvolvimento Humano para falar de ambos no processo de desenvolvimento humano.

Nesse momento de mudança entra em cena nova relação. Inicia-se a parceria com a Orientadora. Ela prontamente compreendeu o árduo trabalho que tinha em suas mãos. Era muito gratificante dizer aos outros que pesquisaria todos os elementos que compunham nosso mestrado, mas, eu pouco sabia deles. Minha pesquisa seria um esclarecimento conceitual, antes de tudo, a mim mesmo. E a professora Ana Reis assumiu prontamente este trabalho comigo. Ajudou-me a fazer de minha ignorância o impulso para construirmos o projeto atual. 
Ela, como estudiosa da interdisciplinaridade, ofereceu-me questões para reflexão que se apresentam em diversos momentos de minha escrita. E que conste aqui, quantas vezes partilharmos questionamentos para que eu os levasse para casa e buscasse por minhas forças a resposta adequada. Há uma relação forte de confiança que nos leva a bons resultados. Eu acredito que ela possa me orientar corretamente e ela acredita que eu possa oferecer sempre bons resultados. Isso tem produzido o bom resultado atual.

E que não se engane quem pensa que nesta relação tudo são flores. Há momentos em que visões singulares levam-nos a conflitos fortes. Quantas vezes ouvi que os métodos que havíamos definido da orientação anterior deveriam ser alterados. Quantas vezes, depois de um complexo trabalho intelectual, solicitavam de mim que recomeçasse buscando outro caminho. Muitas vezes essa indefinição, sobretudo quanto aos métodos de pesquisa, foram meus maiores obstáculos.

Não era fácil remodelar aquilo que havíamos planejado, mas, essa boa e produtiva relação que há entre nós permitia que seguíssemos adiante. E a cada momento de apresentação, a cada banca examinadora, os comentários elogiosos e os apontamentos corretivos indicavam que estávamos realmente no caminho correto.

A verdade é que, passada toda a crise que as trocas de perspectiva podem proporcionar, parece fácil a decisão. Mas, realmente não foram. Contudo, foi com elas que entendi o que significava avançar para um campo mais complexo, resultante de um desenvolvimento.

Em uma de nossas apresentações, em um dos seminários que a turma de 2010 realizou, uma de minhas amigas de mestrado gravou parte de nossas falas. Quando tive a oportunidade de ver como me portava diante deles, de como escolhia cada palavra senti muito orgulho de mim mesmo. O que presenciei naquele vídeo significava uma mudança até então despercebida.

Entendi que mais do que amadurecer intelectualmente, amadureci como pessoa. Pude, nas oportunidades que me foram dadas, oferecer tudo aquilo que pensava, encontrei sempre o espaço para partilhar meus pensamentos e com isso entendi, por exemplo, o que é interdisciplinaridade.

Mas, fiquei verdadeiramente feliz, quando reconheci naquele vídeo elementos que não estavam em nenhuma das literaturas que nos foram oferecidas. Estavam realmente nas pessoas com que fui interagindo ao longo dos meses desse 
mestrado. A confiança nas próprias ideias, o preparo para o erro, são apenas algumas características herdadas desse bom convívio. Os amigos que fiz ao longo desse tempo permitiram que chegasse até aqui com todo o sucesso. Sozinho, talvez tivesse sucumbido diante do primeiro desafio. Porém, a exemplo deles, segui em frente. E sei que muitas vezes servi também eu de apoio para eles.

Essa sustentação partilhada pelos componentes do mestrado tornou-se ainda mais necessária no momento da qualificação. A confiança construída nos meses de curso quase ruiu frente aos comentários da banca examinadora. Entender que a avaliação feita significava uma purificação da pesquisa, que representava uma delimitação ainda necessária, não foi tarefa fácil, mas, após alguns instantes de reflexão, novamente me coloquei a trabalhar. E o resultado é esse trabalho que agora chega para a banca de defesa de mestrado.

Por fim, talvez, pudesse elaborar um memorial que salientasse meus ganhos individuais. Com certeza encontraria momentos em que a ação individual me elevaria a um bom status. Mas, não seria este texto verdadeiro. Não cumpriria seu objetivo em destacar minha história, pois essa não é nunca individual. Os amigos que compõem comigo o quadro de alunos de mestrado em Desenvolvimento Humano me ajudaram a entender o que significava desenvolvimento humano antes mesmo de termos a consciência teórica de tal conceito.

Aprendi na prática o que significa partilhar o que se aprende, dividir dúvidas e construir a várias mãos um conhecimento verdadeiro. Minha vida toda, sobretudo o período do mestrado, é digno de nota porque agrega sempre mais pessoas. Porque a história que narro se liga a outras histórias num emaranhado de amizade.

Agora, prestes a realizar a defesa, a cada nova apresentação, ali diante da banca não me sinto só. Mesmo com a impossibilidade de estarmos todos reunidos no mesmo horário, quando falo, falo a quem me escuta sobre as coisas que aprendi com eles. E quando me ponho a escutar minha própria voz reconheço a segurança de quem fala com propriedade, de quem conseguiu compreender a teoria, mais ainda, de quem conseguiu vivenciar a teoria. 


\section{ANEXO A}

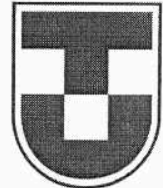

PRPPG-Pró-reitoria de Pesquisa e Pós-graduação

Comitê de ética em Pesquisa

Rua Visconde do Rio Branco, 210 Centro Taubaté-SP 12020-040

Tel: (12) $3625.4143-3635.123$ Fax: (12) 3632.2947

UNITAU

\section{DECLARAÇ̃̃O No 039/11}

Protocolo CEP/UNITAU $\mathbf{n}^{\circ}$ 018/11 (Esse número de registro deverá ser citado pelo pesquisador nas correspondências referentes a este projeto)

Projeto de Pesquisa: A atitude interdisciplinar docente como propulsora do desenvolvimento humano no ensino médio

Pesquisador(a) Responsável: Daniel de Carvalho Costa

O Comitê de Ética em Pesquisa, em reunião de 11/02/2011, e no uso das competências definidas na Resolução CNS/MS 196/96, considerou o Projeto acima Aprovado.

Taubaté, 11 de fevereiro de 2011

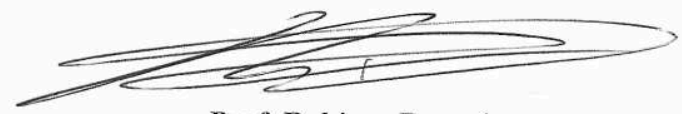

Prof. Robison Baroni

Coordenador do Comitê de Ética em Pesquisa da Universidade de Taubaté 